UNIVERSIDADE DE SÃO PAULO

INSTITUTO DE GEOCIÊNCIAS

\title{
REAVALIAÇÃO DE ESTRUTURAS DE POSSÍVEL ORIGEM BIOGÊNICA (ICNOFÓSSEIS, DUBIOFÓSSEIS E ESTRUTURAS ASSOCIADAS) DO GRUPO ALTO PARAGUAI (VENDIANO OU CAMBRIANO), MT
}

\section{PAULO ROBERTO FERREIRA DE ALBUQUERQUE}

Orientador: Dr. Thomas Rich Fairchild

DISSERTAÇÃO DE MESTRADO

COMISSÃO JULGADORA

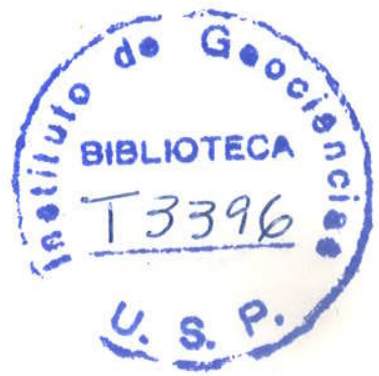

Nome

Presidente: Prof. Dr. Thomas Rich Fairchild

Examinadores: Prof. Dr. Paulo Cesar Fonseca Giannini

Prof ${ }^{\text {a. }} \cdot$ Dr $^{\mathrm{a} \cdot}$ Renata Guimarães Netto
Assinatura
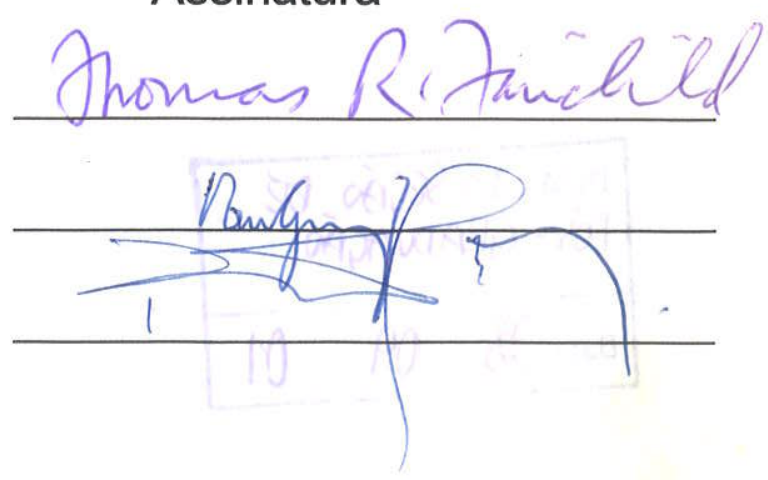


\section{UNIVERSIDADE DE SÃO PAULO INSTITUTO DE GEOCIÊNCIAS}

\section{REAVALIAÇÃO DE ESTRUTURAS DE POSSÍVEL ORIGEM BIOGÊNICA (ICNOFÓSSEIS, DUBIOFÓSSEIS E ESTRUTURAS ASSOCIADAS) \\ DO GRUPO ALTO PARAGUAI (VENDIANO OU CAMBRIANO), MT}

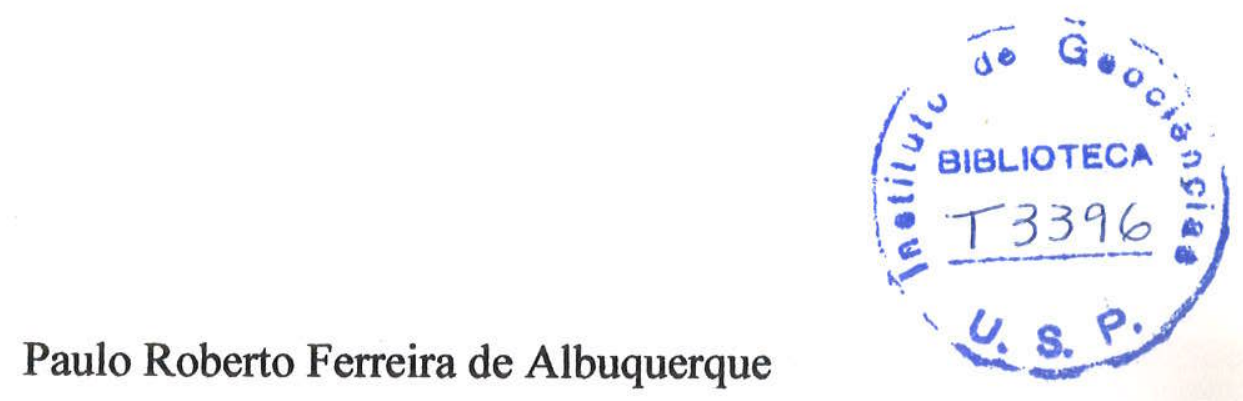

Orientador: Prof. Dr. Thomas Rich Fairchild

DISSERTAÇÃO DE MESTRADO

Programa de Pós-Graduação em Geologia Sedimentar

SÃO PAULO

2001

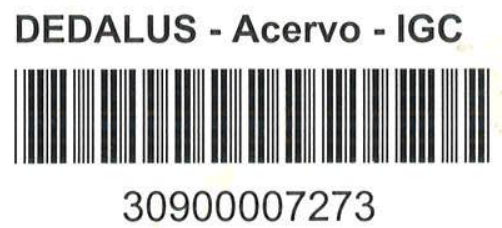


Dedico este trabalho à memória do meu avô José de Oliveira Fabrino 


\section{Agradecimentos:}

Ao orientador Prof. Dr. Thomas Rich Fairchild por seu empenho, paciência e dedicação. Também por seu auxílio, imprescindivel, no fornecimento de referências bibliográficas de seu acervo particular. Ao amigo Thomas Fairchild pelo apoio, muito além dos aspectos desta dissertação, pelas infinitas horas em que se privou do convívio com sua família, para estar a meu lado até tarde da noite e por finais de semana inteiros.

Ao coordenador do curso de pós-graduação em Geologia Sedimentar Prof. Dr. Claudio Riccomini pelo apoio, Ao Prof. Dr. Paulo César Giannini pelos comentários a respeito das estruturas sedimentares. Aos demais professores do IG/USP pelos valiosos ensinamentos e contribuições ao longo do curso de mestrado.

Aos Prof. Dr. Antonio Carlos Sequeira Fernandes, Alcina Magnólia Franca Barreto, Leonardo Borghi e Mitsuru Arai pelo auxílio na busca de referências bibliográficas.

A todos os funcionários do Instituto de Geociências, em especial aos da biblioteca e da gráfica, por seu auxílio e prontidão em resolver problemas nos momentos mais críticos desta jornada. Ao funcionário Paulo Augusto Morgato pelos cortes "emergenciais" nas amostras estudadas.

Ao geólogo José Artur Andrade (DNPM/Crato) pela colaboração e apoio logístico nos trabalhos de campo na região do Araripe. Ao geólogo Gerald Bartram pelo incentivo na realização deste trabalho.

Ao colega de pós-graduação Afonso Nogueira pelos comentários a respeito do Grupo Alto Paraguai. Aos também colegas Alexandre Tomio, André Ferrari, Ivo Trosdtorf Jr., Jefferson Oliveira, Leandro Donatti, Maria da Glória Garcia, Renata Hidalgo, Renato Ghilardi e Willian Sallun Filho pelo apoio e incentivo. 
Aos amigos e também colegas: Claudio Pires Florencio pelo auxílio na obtenção de imagens escaneadas; Alexandre Magno Feitosa Sales pela colaboração nos trabalhos de campo e na discussão dos dados obtidos na Chapada do Araripe; e Patricia de Souza Cristalli pelo auxílio na confeç̧ão deste volume. Ao três pelo incentivo, apoio, e principalmente pela sua amizade ao longo destes anos.

Ao meu sogro Cesar Ricardo Cristalli, pelo apoio incondicional e imprescindível na confeç̧ão das figuras contidas neste volume.

Aos amigos Alexandre Novelino Simão, Fernando Araújo Castro, Julio César Padovan, Plácido Russo Jr., Vitor Brasil de Resende, Fábio e Candinha Martins, e tantos outros que acreditaram no sucesso desta jornada.

Aos meus primos, cuja lista seria por demais extensa. Em especial a Gisele Fabrino Machado pelo incentivo incessante ao longo destes anos.

Finalmente, as mulheres da minha vida: minha mãe Lucia Fabrino Ferreira de Albuquerque e a minha irmã Ana Lucia Ferreira de Albuquerque, pelo apoio e incentivo, não só ao longo deste mestrado mas por toda minha jornada; a minha esposa Flávia de Souza Cristalli Albuquerque, cujo incentivo e compreensão foram fundamentais para o término deste volume; e a minha filha, que vai nascer quase junto com este volume, pelos inúmeros momentos inesqueciveis de alegria que me deram conforto e esperança nas longas horas que foram necessárias para finalizar este volume. 


\section{Resumo}

O estudo dos icnofósseis (icnologia) é uma importante ferramenta paleontológica, tanto para a compreensão das importantes inovações do Proterozóico terminal (Vendiano) e da expansão dos animais megascópicos do início do Cambriano, quanto para a identificação e correlação do limite Pré-Cambriano/Cambriano. A sua grande limitação é a dificuldade em se distinguir entre fósseis verdadeiros (como icnofósseis e moldes de metazoários do tipo fauna de Ediacara) e estruturas sedimentares abiogênicas dentre os abundantes objetos desta idade suspeitos de serem biogênicos. Os critérios para fazer esta distinção foram inicialmente testados em objetos simples e cilíndricos da Formação Cariri (Bacia do Araripe, NE), de idade controversa mas seguramente Fanerozóica, e então aplicados em um diversificado conjunto de objetos previamente descritos como icnofósseis e dubiofósseis da Formação Raizama (Vendiano ou Cambriano) do Grupo Alto Paraguai (Faixa Paraguai, Mato Grosso). Estas análises estabeleceram a biogenicidade dos objetos da Formação Cariri, tornando-os os três primeiros icnofósseis de invertebrados descritos nesta unidade, mas levantaram dúvidas quanto a biogenicidade do material da Formação Raizama, classificando entre eles cinco pseudofósseis, um provável pseudofóssil, três possíveis pseudofósseis e um dubiofóssil. Esta conclusão implica em situações (ambientais e/ou cronológicas) não favoráveis ao desenvolvimento de vida. Mas, não pudemos descartar totalmente a presença de objetos de origem biológica. Esta condição deve ser investigada com a pesquisa sistemática e exaustiva desta unidade em busca de indícios que confirmem (ou não) a presença de vestígios de vida nesta unidade. Desta forma, a Formação Raizama pode ser considerada, no máximo, como dubiamente fossilífera. 


\begin{abstract}
The study of trace-fossils (ichnology) is a major paleontological tool both for understanding important innovations in the latest Proterozoic (Vendian) and earliest Cambrian expansion of megascopic animals and for identifying and correlating the Precambrian/Cambrian boundary. Its greatest limitation is the difficulty in distinguishing between true fossils (such as ichnofossils and Ediacara-like metazoan molds) and abiogenic sedimentary structures among the abundant simple objects of this age suspected of being biogenic. Criteria for making this distinction were initially tested on simple tubular and cylindrical objects in the Cariri Formation (Araripe Basin, NE Brazil), of disputed, but assuredly Phanerozoic age, and then applied to a diverse set of objects previously described as ichnofossils and dubiofossils from the Vendian or Cambrian Raizama Formation (Alto Paraguai Group) (Paraguai Belt, Mato Grosso, Brazil). These analyses established the biogenicity of the objects in the Cariri Formation, making them the first three ichnofossils of invertebrate origin described from this unit, but cast doubt on the biogenicity of the Raizama material, showing it to consist practically entirely of abiogenic objects with five pseudofossils, one probable pseudofossil, three possible pseudofossils, and a single dubiofossil. This conclusion requires either that reasons for this formation's inhospitality to life be sought through reinterpretation of its age or paleoenvironment or, as is more likely, that this condition be disproved (or confirmed) by exhaustive, systematic search for fossils in this unit. For the time being, however, the Raizama Formation must be considered no more than only doubtfully fossiliferous.
\end{abstract}




\section{Índice}

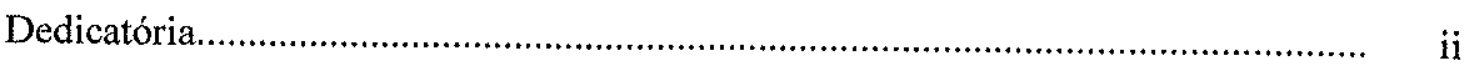

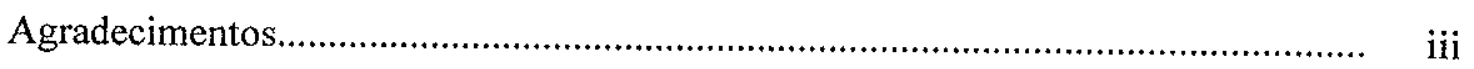

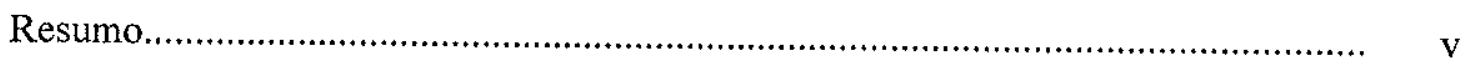

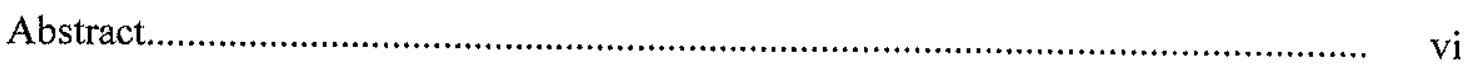

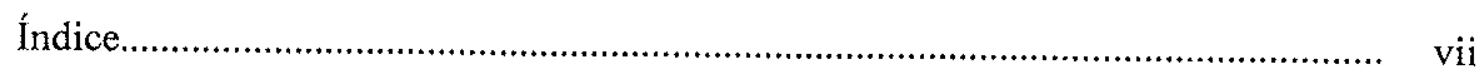

Lista de Figuras.......................................................................................... ix

Lista de Tabelas.......................................................................................... xii

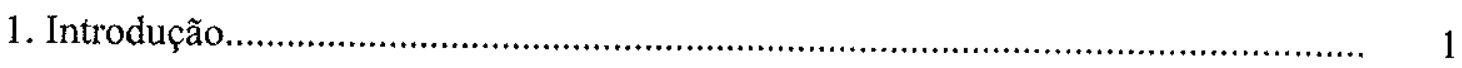

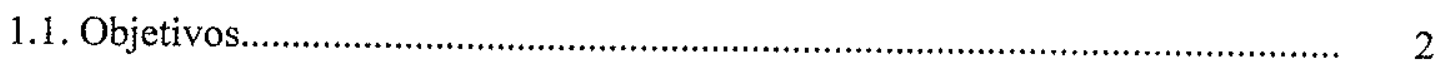

1.2. Materiais e Métodos.................................................................................. 3

1.3. Hipóteses de trabalho................................................................................ 3

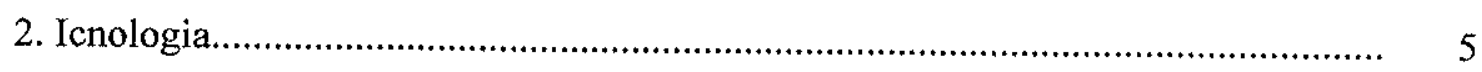

2.1 Introdução............................................................................................. 5

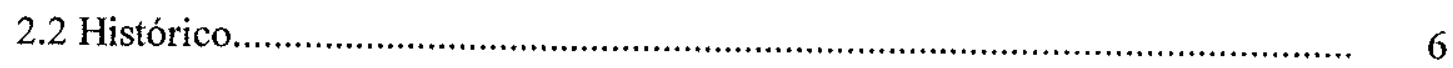

2.3 Icnofósseis vs. Fósseis Corpóreos................................................................ 8

2.4 Importância dos Icnofósseis.................................................................... 10

3. A Caracterização e Classificação de Icnofósseis.................................................. 14

3.1. Caracterização de Icnofósseis................................................................... 14

3.2. Classificação de icnofósseis...................................................................... 18

3.2.1. Classificação taxonômica....................................................................... 19

3.2.2. Classificação dos icnofósseis de acordo com sua forma preservacional.... 22

3.2.3. Classificação Etológica dos Icnofósseis................................................... 26

3.2.4. A Proposta de Classificação de Vialov....................................................... 29

4. Os Icnofósseis e a transição Pré-Cambriano/Cambriano....................................... 30

4.1. O zoneamento icnológico da transição Pré-Cambriano/Cambriano................ 32

4.2. A seqüência estratótipo do limite Pré-Cambriano/Cambriano......................... 45

4.3. Diversificação dos icnofósseis na transição Pré-Cambriano/Cambriano.......... 47

5. Icnofósseis da Formação Cariri, Bacia do Araripe................................................ 53

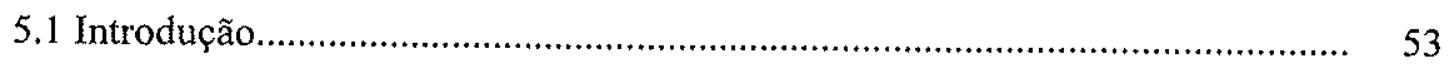

5.2. Contexto Geológico................................................................................ 54 
5.3. Ocorrência dos objetos analisados.......................................................... 58

5.4. Descrição litológica da amostra.................................................................. 60

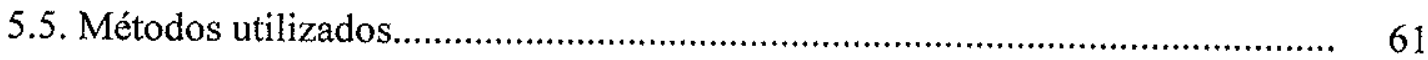

5.6. Caracterização dos objetos....................................................................... 62

5.7. Orientação dos objetos................................................................................ 65

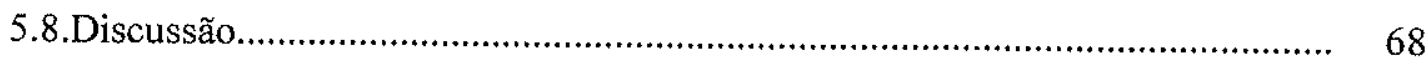

6. Os supostos icnofósseis do Grupo Alto Paraguai................................................ 73

6.1.Introdução................................................................................................... 73

6.2. Contexto Geológico................................................................................ 74

6.3. Avaliação dos objetos................................................................................ 77

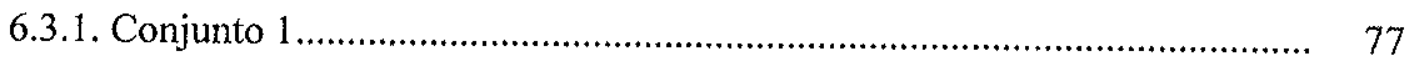

6.3.1.1. Amostra GP/7E-210 (Amostra 4 de 2.2.86)...................................... 78

6.3.1.2. Amostra GP/7E-213 (Amostra 2 de 2.2.86) .................................... 80

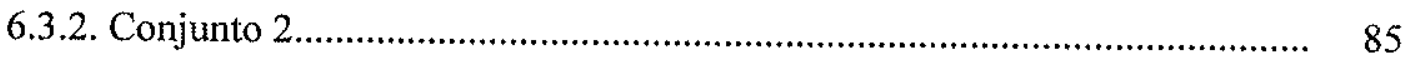

6.3.2.1. Amostra GP/7G-211 (Amostra 2 de 3.2.86)..................................... 85

6.3.2.2. Amostra GP/7E-215 (Amostra 1 de 3.2.86) .................................... 87

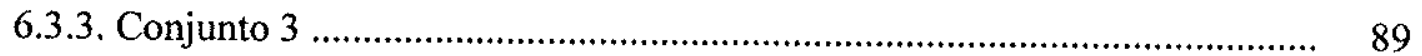

6.3.3.1. Amostra GP/7E-212 (Amostra 4 de 1.2.86)...................................... 90

6.3.3.2. Amostra GP/7E-214 (Amostra 6 de 1.2.86)....................................... 92

6.3.3.3. Amostra GP/7E-216 (Amostra 1 de 1.2.86)........................................ 94

6.3.3.4. Amostra GP/7E-218 (Amostra 3 de 1.2.86)....................................... 96

6.3.3.5. Amostra GP/7E-219 (Amostra 2 de 1.2.86) ...................................... 97

6.3.3.6. Amostra GP/7E-220 (Amostra 5 de1.2.86)....................................... 99

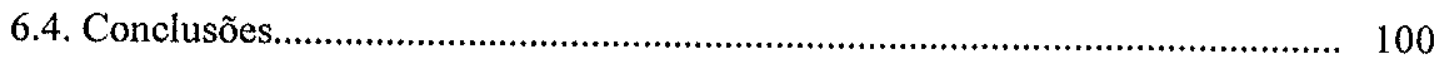

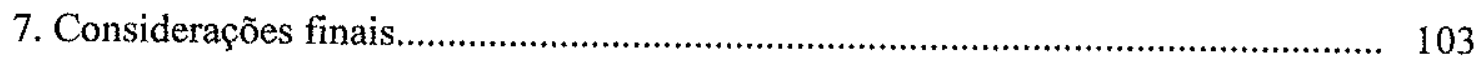

8. Referências bibliográficas.......................................................................... 105 


\section{Índice de Figuras}

Figura 2.1 - Diferentes icnofósseis gerados de acordo com o comportamento diferenciado de um mesmo trilobita (Adaptado de Seilacher 1964b).

Figura 2.2 --Geração de pegadas humanas diferentes em diferentes substratos. a) em papel fotográfico; b) em areia seca; c) em areia molhada; e d) em lama. (Adaptado de Bromley 1990)......

Figura 2.3 - Distribuição esquemática das icnofácies em um ambiente marinho. APós-praia e dunas litorâneas; B- Região litorânea de baixa energia; C-Região de baixa energia e da plataforma; D- Região do talude e zonas abissal e batial. (Modificado de Pemberton et al., 1990).

Figura 3.1 - Preservação rara, do organismo gerador junto aos icnitos produzidos por ele (Extraída de Häntzschel, 1975).

Figura 3.2 - Classificação das ramificações segundo D'Alessandro \& Bromley (1987): falsa (a); secundária sucessiva (b); primária sucessiva (c); e simultânea (d). (modificada de Bromley, 1990).

Figura 3.3 - Comparação dos conceitos e terminologia nas classificações preservacionais de Seilacher (1964a) e Martinsson (1965 e 1970), segundo Bromley (1990).

Figura 3.4 - Classificação preservacional e processo de geração de icnofósseis (Extraída de Carvalho e Fernandes 2000, original de Seilacher 1964b).

Figura 3.5 - Comparação dos conceitos e terminologia nas classificações preservacionais de Chamberlain (1971) e Simpson (1957). (Modificada de Pemberton, 1992).

Figura 3.6 - Classificação etológica dos icnofósseis. (Extraída de Carvalho \& Fernandes, 2000. Original de Seilacher, 1953).

Figura 3.7 - Classificação etológica dos icnitos (Frey et al., 1987).

Figura 4.1 - Subdivisões da metade final do Proterozóico e do Cambriano Inferior, de acordo com a nomenclatura russa. O limite Proterozóico/Cambriano é definido

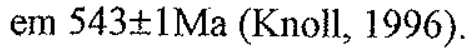

Figura 4.2 - Icnofósseis do Vendiano. Na parte superior, os que ocorrem também no Fanerozóico. Na parte inferior, aqueles que ocorrem somente no Vendiano (Modificada de Crimes, 1994)... 
Figura 4.3 - Representação gráfica de alguns importantes icnofósseis Fanerozóicos com registro no Cambriano (Modificada de Crimes, 1994).

Figura 4.4 - Distribuição das biozonas Harlaniella podolica(A), Treptichnus pedum(B) e Rusophycus avalonensis $(\mathrm{C})$. Os pontos pretos indicam a presença das espécies típicas destas zonas e os pontos brancos indicam a presença de outras espécies ou assembléias destas zonas. (Modificado de Narbonne \& Myrow, 1987).....

Figura 4.5 - Divisão do intervalo Pré-Cambriano/Cambriano de Narbonne \& Myrow (1987) para as formações Chapel Island e Random, baseada na bioestratigrafia dos icnofósseis

Figura 4.6 - Relação da diversidade de icnogêneros (aparição, extinção e total de icnogêneros) nas biozonas de Crimes (1994) - R-Rifeano; V-Varangeriano; EdEdiacariano; PEPC- Pós-Ediacariano, Pré-Cambriano; PTC- Cambriano Inferior PréTrilobita; TLC- Cambriano Inferior com Trilobitas; MC-Cambriano Médio; UCCambriano Superior. (Modificada de Crimes, 1994).

Figura 4.7 - Relação entre a diversidade de icnofósseis e de fósseis corpóreos nas biozonas de Crimes (1994). - V-Varangeriano; Ed-Ediacariano; PEPC- PósEdiacariano, Pré-Cambriano; PTC- Cambriano Inferior Pré-Trilobita; TLCCambriano Inferior com Trilobitas; MC-Cambriano Médio; UC-Cambriano Superior. (Modificada de Crimes, 1994).

Figura 4.8 - As biozonas e suas relações com as icnozonas e a seqüência estratótipo da transição Pré-Cambriano/Cambriano (Modificada de Crimes, 1994).

Figura 4.9 - Algumas localidades de importantes seções do limite Pré-Cambriano/ Cambriano (círculos numerados). As seqüências candidatas a estratótipo do limite Pré-Cambriano/Cambriano estão representadas pelos pontos em destaque, 14 (Aldan River, Antiga URSS), 19 (Meishucun, China) e 35 (Península de Fortune Head Península Burin, Canadá). O ponto 41 corresponde ao Grupo Corumbá-MS (Modificado de Cowie, 1992)......

Figura 4.10 - Relação entre a diversidade de icnogêneros e sua disposição batimétrica, do Pré-Cambriano (PC) ao Terciário (T) (Modificada de Crimes, 1974)..

Figura 4.11 - Aparecimento de diferentes linhagens de icnofósseis no final do PréCambriano e no inicio do Cambriano, com o aumento de sua complexidade morfológica (Modificada de Crimes, 1992).

Figura 4.12 - Desenvolvimento de icnitos simples na transição PréCambriano/Cambriano (Modificada de Crimes, 1992)......

Figura 4.13 - Desenvolvimento de icnitos ramificados na transição Pré-Cambriano /Cambriano (Modificada de Crimes, 1992) 
Figura 4.14 - Desenvolvimento de icnitos estofados e com Spreite na transição PréCambriano/Cambriano (Modificada de Crimes, 1992).

Figura 4.15 - Desenvolvimento de pistas e icnitos de descanso na transição PréCambriano/Cambriano (Modificada de Crimes, 1992)...

Figura 5.1 - Localização geográfica da Bacia do Araripe e de algumas outras bacias interiores do Nordeste (Modificada de Carvalho, 2000)

Figura 5.2 - Quadro comparativo das propostas de colunas estratigráficas da Bacia do Araripe (Extraída de Assine, 1992).

Figura 5.3 - Coluna estratigráfica da Bacia do Araripe proposta por Assine (1990) (Modificada de Assine 1992).

Figura 5.4 - Mapa de localização do afloramento.

Figura 5.5 - Afloramento da Formação Cariri onde ocorrem os icnofósseis.

Figura 5.6 - O pavimento onde ocorrem os icnofósseis. O cabo do martelo está orientado em direção ao norte magnético.

Figura 5.7 - A amostra estudada, logo acima e à direita do martelo, no momento da coleta. O cabo do martelo indica o norte magnético.

Figura 5.8 - (a) Detalhe da amostra no laboratório. As linhas pretas indicam os locais onde a amostra foi serrada para análise dos objetos. (b) $\mathrm{O}$ molde em látex da superficie da amostra. $(\mathrm{x} 0,4)$......

Figura 5.9 - Detalhe da amostra (à esquerda) e do molde em látex (à direita). Os traços lineares representam a Forma 1 e as estruturas circulares a Forma $2(x 0,6) \ldots$

Figura 5.10 - Detalhes da Forma 2 em corte da amostra (à esquerda) e em lâmina (à direita)......

Figura 5.11 - Detalhe da amostra e molde em látex da Forma 3 ( $\mathrm{x} 0,7)$.

Figura 5.12 - Na parte superior, foto do pavimento de icnofósseis (cabo do martelo indica o norte magnético). Na parte inferior, desenho da direção dos icnofósseis baseado na foto. À direita, o resultado da análise de suas direções.

Figura 5.13 -- Na parte superior, foto do pavimento de icnofósseis no local onde foi coletada a amostra (cabo do martelo indica o norte magnético). Na parte inferior, desenho da direção dos icnofósseis baseado na foto. À direita, o resultado da análise de suas direções. 
Figura 5.14 - Na parte superior, foto de detalhe do pavimento de icnofósseis (seta da escala indica o norte magnético). $\mathrm{Na}$ parte inferior, desenho da direção dos icnofósseis baseado na foto. À direita, o resultado da análise de suas direções

Figura 5.15 - Icnofósseis invertebrados da Formação Sousa (Extraída de Carvalho, 2000)

Figura 5.16 - Icnitos parecidos com Formas 1 e 2 atribuídos a animais não identificados do Paleogeno da China. (extraído de Fouch \& Dean, 1982)

Figura 6.1 - Diferentes estratigrafia regionais propostas para a Faixa Paraguai (Extraída de Almeida, 1984)

Figura 6.2 - Coluna estratigráfica de Almeida (1984)

Figura 6.3 - Superficie da amostra GP/7E - 210, com os objetos similares a gretas de contração

Figura 6.4 - Superfície onde ocorrem os objetos (1 e 2) na amostra GP/7E -213 .

Figura 6.5 - Amostra original de onde foi retirada a amostra GP/7E-213 (na área indicada na seta) (Extraída de Zaine, 1991).

Figura 6.6 - Quadro comparativo entre a amostra GP/7E-213 e icnofósseis do gênero Arthrophycus e estruturas sedimentares do tipo Rhysonetron.

Figura 6.7 - Estruturas sedimentares do tipo Rhysonetron (Modificada de Häntzschel, 1975).

Figura 6.8 - Diagrama esquemático com os estágios da formação de Rhysonetron: 1) acumulação de lama; 2) desenvolvimento da greta; 3) preenchimento e recobrimento da lama por areia; 4) compactação da lama e compressão da areia gerando formas fusiformes (estágio do Manchuriophycus); e, 5) posterior redução do volume de lama e compressão das formas fusiformes (estágio do Rhysonetron) (Modificada de Hofmann, 1971).

Fig 6.9 -Objetos na superfície ondulada da amostra GP/7E - 211 (a esquerda) e desenho esquemático da amostra (a direita).

Fig. 6.10 - Gretas em forma de 8 na Formação Águas Claras, Arqueano do Pará (Extraída de Nogueira, 1995).

Fig 6.11 - Objeto na superficie da amostra GP/7E -215 (a esquerda) e desenho esquemático do objeto visto em corte transversal (a direita).

Figura 6.12 - Detalhe de parte da amostra GP/7E-212 (à esquerda) e desenho esquemático da superficie onde ocorrem os objetos na amostra GP/7E -212 . 
Figura 6.13 - Objeto na superficie da amostra GP/7E - 214

Figura 6.14 -- Objeto salientado por contorno a lápis na amostra GP/7E - 216 ......

Figura 6.15 - $\grave{A}$ esquerda a amostra GP/7E-218 e a direita cristas de adesão modernas (Foto das cristas extraída de Allen, 1984).

Figura 6.16 - Objeto na superfície da amostra GP/7E-219

Figura 6.17 - Rosa do deserto de barita em visão superior (à esquerda) e visão lateral (à direita).

Figura 6.18 - Amostra GP/7E-220

Figura 6.19 - Comparação das interpretações apresentadas por de Zaine (1991) e do presente trabalho.

\section{Índice de Tabelas}

Tabela 4.1 - As três zonas de Crimes (1987) e suas respectivas associaçôes de Icnogêneros. (Modificada de Crimes, 1989).

Tabela 4.2 - Distribuição dos icnogêneros nas diferentes biozonas de Crimes (1994). R-Rifeano; V-Varangeriano; Ed-Ediacariano; PEPC- Pós-Ediacariano, PréCambriano; PTC- Cambriano Inferior Pré Trilobita; CI- Cambriano Inferior. (Modificada de Crimes, 1994).

Tabela 4.3 - Distribuição etológica dos icnitos da transição Vendiano/Cambriano (Modificada de Crimes, 1992) 


\section{Introdução}

O estudo de formas de vida eucariótica no Pré-Cambriano, importante para nosso entendimento da transição do mundo de vida predominantemente microscópica do Proterozóico para o mundo dominado por organismos megascópicos do Fanerozóico, é baseado em microfósseis, icnofósseis, moldes e impressões de metazoários primitivos. Os microfósseis (acritarcas) são, sem dúvida, os mais abundantes e importantes para tecer a história da vida até o aparecimento dos primeiros metazoários megascópicos pouco antes do fim do Proterozóico. No entanto, quando se estudam formas megascópicas de vida nesta parte do registro fóssil, que corresponde aproximadamente aos últimos 60 milhões de anos (Ma) do Pré-Cambriano (600-543 Ma), os icnofósseis são os fósseis mais abundantes, sendo relativamente raros os moldes e impressões de metazoários do tipo que caracteriza a mais antiga fauna conhecida, a fauna de Ediacara, inicialmente descrita no sul da Austrália mas hoje conhecida de mais de duas dezenas de localidades no mundo (Glaessner, 1984; Fedonkin, 1994). A importância dos icnofósseis no estabelecimento de uma bioestratigrafia da parte final do Neoproterozóico e início do Cambriano já foi salientada por diversos pesquisadores (Glaessner, 1984; Hofmann, 1987; Crimes, 1987, 1992, 1994). De fato, foi em boa parte com base nos icnofósseis que se definiu o limite Pré-Cambriano/Cambriano no estratótipo desta transição, localizado no extremo leste do Canadá (Cowie, 1992; Narbonne et al., 1987)

Os icnofósseis são, portanto, um importante registro da história evolutiva da vida na transição Pré-Cambriano/Cambriano (ver Crimes, 1994). Este fato reforça a necessidade da reavaliação dos objetos descritos por Zaine (1991) do Grupo Alto Paraguai, região de Cáceres, MT, como evidências de metazoários desta transição e, até agora, os únicos fósseis assinalados desta unidade litoestratigráfica. 


\subsection{Objetivos}

O objetivo do presente trabalho é a análise dos conceitos, aplicações e limitações da icnologia, aplicando a à interpretação de objetos de provável idade pré-cambriana e de possível origem biogênica, levantando os pontos pró e contra esta origem. Os objetos analisados neste trabalho foram, com uma exceção, coletados por Mariselma F. Zaine e a maioria deles descritos por ela na tese de doutoramento (Zaine, 1991).

Estes objetos pertencem à Formação Raizama do Grupo Alto Paraguai e foram coletados na região de Cáceres, MT. Por causa de sua idade (entre o Pré-Cambriano ou Cambriano) e possíveis afinidades biológicas (pistas ou impressões de invertebrados primitivos), estes objetos foram re-estudados neste trabalho, buscando-se estabelecer seus verdadeiros modos de formação. No caso dos objetos cuja origem biológica é aqui refutada, são propostos mecanismos para explicar a sua formação. Aqueles objetos cuja origem biológica não pôde ser confirmada nem refutada, são classificados numa escala de biogenicidade relativa de sete categorias, desde pseudofóssil passando por dubiofóssil até icnofóssil, de acordo com a força das evidências e argumentos disponíveis.

Uma amostra coletada da Formação Cariri da Bacia do Araripe constitui a exceção ao material de Zaine estudado neste trabalho. A inclusão desta amostra é justificada pela situação paleontológica das duas formações, mesmo que uma seja do início do Fanerozóico, ou mais antiga, e a outra do Devoniano, ou mais recente. Especificamente, ambas apresentam litologias similares (arenitos, arenitos conglomeráticos, não muito maturos), foram consideradas afossiliferas, e tiveram como seus primeiros registros fósseis, a presença de icnofósseis. O estudo destes objetos, coletados em afloramento e sabidamente fanerozóicos, permitiu aperfeiçoar as técnicas e métodos de estudo necessários para a análise dos objetos da Formação Raizama, de idade e origem mais problemáticas. 


\subsection{Materiais e Métodos}

As amostras utilizadas para os estudos paleoicnológicos se dividem em dois grupos: a) as previamente coletadas, que se encontram depositadas nas coleções paleontológicas do Instituto de Geociências (Fig. 6.18); e b) as coletadas em excursão de campo à Bacia do Araripe, realizada em 1998.

As estruturas presentes nas amostras estudadas foram tratadas e assim denominadas como "objetos" para evitar a utilização de qualquer tipo de nomenclatura, principalmente nas amostras descritas por Zaine (1991), que pudesse gerar algum tipo de tendência interpretativa. Este tratamento foi utilizado ao longo de todo trabalho, sendo finalizado com a classificação destes objetos quanto a sua origem.

Os estudos paleoicnológicos foram constituídos de: a) descrição petrográfica macroscópica das amostras, com o auxílio de lupa binocular e, quando necessário, análise de lâmina delgada; b) descrição morfométrica dos objetos; c) moldagem em látex (Kummel \& Raup, 1965); d) reprodução fotográfica das amostras; e e) identificação de possíveis afinidades e classificação dos objetos.

\subsection{Hipóteses de trabalho}

Os estudos prévios das amostras das formações Raizama e Cariri (Zaine, 1991; Albuquerque et al. 1999, 2000) relatam a presença de icnofósseis. A confirmação deste conteúdo fóssil abriria novas perspectivas para a datação e interpretação paleobiológica e paleoambiental destas formações.

A análise dos objetos estudados leva em consideração duas hipóteses principais, ainda que não excludentes: a) a confirmação destes objetos como icnofósseis; e b) a exclusão de uma origem biogênica para estes objetos. $\mathrm{Na}$ hipótese de se concluir por uma origem não 
biogênica de todos os objetos, os processos de geração destes devem ser explicados e as interpretações geocronológicas e paleoambientais decorrentes de suposta presença de fósseis nessas formações postas em xeque.. No entanto, basta que se confirme um único objeto como biogênico para que estas formações passem a ser interpretáveis em outro contexto. Por exemplo, Os icnofósseis da Formação Raizama, Grupo Alto Paraguai, poderiam se juntar a uma série de outras ocorrências de icnofósseis da transição PréCambriano/Cambriano conhecidas na América do Sul (Netto et al., 1992; Ciguel et al., 1992; Muniz, 1980). Confirmada sua origem biológica os icnofósseis da Formação Cariri se tornariam um importante registro fossilífero (e o primeiro de icnofósseis de invertebrados) nestas rochas consideradas até muito pouco tempo afossiliferas. 


\section{Icnologia}

\subsection{Introdução:}

Icnologia (do grego, iknos - traço, pista e logos - estudo) é o estudo de estruturas biogênicas (icnitos) fósseis ou recentes. Icnologia também pode ser definida como o estudo de pegadas, pistas, tubos, tocas e outros traços feitos por organismos recentes e antigos (Frey, 1975a). A icnologia pode ser dividida em neoicnologia (estudo dos icnitos recentes) e paleoicnologia (estudo dos icnitos fósseis). O termo icnofóssil abrange uma grande e variada gama de vestígios fósseis, tais como traços, tubos, pegadas, coprólitos, gastrólitos e até ovos, uma vez que esta última categoria de objetos não constitui um elemento esqueletal nem corpóreo do animal que o produz. A definição de icnofósseis como estruturas em sedimentos produzidas por atividade animal, embora simples e em grande parte adequada, encerra algumas restrições ligadas principalmente à interpretação das palavras sedimento, atividade e animal (Martinsson, 1970), à possibilidade destes traços serem produzidos por outros organismos vivos, como nas definições de Haas (1954) e Seilacher (1955). Simpson (1957) restringiu esta definição, citando a necessidade do deslocamento do animal no sedimento, ainda durante a sedimentação.Também neste mesmo período Lessertisseur (1955) adotou o termo "trace d'activité" para os icnofósseis, onde a necessidade de atividade do organismo já está implícita no próprio termo. Segundo a definição de Häntzschel (1975), uma das mais explicativas, os icnofósseis são estruturas produzidas em sedimentos moles/inconsolidados e em substratos duros/consolidados como resultado da atividade de organismos vivos, incluindo, assim, pegadas e pistas na superficie, túneis e tocas (burrows e borings) na subsuperfície, bem como material fecal e até marcas produzidas por animais mortos. A definição mais abrangente, no entanto, é a de Pickerill (1994), que coloca os icnofósseis como os restos fossilizados de estruturas produzidas, sobre ou dentro do substrato, pela atividade de organismos. 


\subsection{Histórico}

A história da icnologia de invertebrados foi subdividida por Osgood (1970) em três etapas: A primeira remete ao século XIX, compreendendo o período anterior a 1881 e denominado como a idade dos "fucóides". Nesta época vários icnofósseis foram interpretados como vestígios de algas marinhas parecidas com membros da Classe Phaeophyceae, (algas pardas) da Divisão Chromophyta. Desta forma, muitos foram nomeados com o sufixo -phycus devido a esta suposta origem algácea (e.g. Zoophycus, Palaeophycus, Spirophycus). A segunda etapa, entre 1881 e 1920, foi a da controvérsia, quando a origem vegetal dos fucóides foi questionada por diversos autores (Nathorst, 1881 e 1886; James, 1884 e 1885; Maillard, 1887; Fuchs, 1895). Mesmo assim, ainda é possivel encontrar hoje na literatura autores que classificam icnofósseis como fucóides (ver Andrews, 1970, e o próprio Glossary of Geology de Bates \& Jackson, 1987, p. 262). Finalmente, surge a etapa moderna, a partir da década de 20, com o desenvolvimento da icnologia atual, iniciada com os trabalhos de Rudolf Richter $(1927,1928,1931)$. Entre a década de 20 e o início dos anos 50, o campo progrediu lentamente (com os primeiros avanços na área sintetizados por Abel, 1935 apud Osgood, 1975a) através de trabalhos realizados principalmente por autores alemães, com destaque para Häntzchel. O salto no progresso da icnologia moderna se iniciou com as publicações de Seilacher (1953, 1955, 1964a e 1964b), em que o potencial de aplicação do estudo de icnofósseis começou a ser demonstrado e os primeiros conceitos de icnofácies e métodos de classificação etológica e preservacional de icnofósseis elaborados. Um grande avanço no estudo dos icnofósseis veio, por intermédio de Häntzchel em 1962, com a publicação do primeiro catálogo descritivo e ilustrado sobre o assunto no Treatise of Invertebrate Paleontology. Häntzchel publicaria ainda mais dois catálogos, um em 1965 e o outro (já postumamente) em 1975.

Nos mais de 30 anos desde a análise histórica de Osgood (1970), a ciência da icnologia atingiu um grau de refinamento e maturidade nunca antes visto, sendo hoje em dia vista como parte integrada e indispensável não apenas da Paleontologia como também da Sedimentologia. A partir da década de 70, uma série de publicações reunindo os conceitos de icnologia, por exemplo, os volumes editados por Crimes \& Harper (1970 e 1977) no 
Geological Journal, a revisão e expansão do suplemento W do Treatise of Invertebrate Paleontology (Häntzchel, 1975), os cursos curtos da SEPM (Basan, 1978a) e da Paleontological Society (Maples \& West, 1992), os livros de Frey (1975b), Bromley (1990) e Donovan (1994), e o lançamento em 1990 da revista Ichnos, bem como uma série de publicações especiais em revistas e cursos do tipo "short courses" de icnologia, ajudaram na divulgação e desenvolvimento da icnologia. A intensidade deste desenvolvimento foi tanta que Ekdale et al. (1984) sugeriram que a icnologia estaria vivendo a sua "época de ouro".

No Brasil os primeiros registros de icnofósseis ocorrem com as descrições de camadas bioturbadas (Derby, 1879; Clarke, 1899; Leinz, 1937), pegadas (Moraes, 1924; Huene, 1931) e rastros (Maury, 1927; Carvalho, 1936). Desde então, diversos trabalhos foram realizados e grande número de icnofósseis relatados no Brasil. Estes traballos se dividem em três principais categorias: a) trabalhos de cunho geológico onde são citados bioturbações e icnofósseis (Almeida, 1954; Rocha-Campos, 1967; Petri, 1985); b) trabalhos de cunho paleontológico relatando e descrevendo icnofósseis (Fernandes \& Netto, 1985; Leonardi \& Sarjeant, 1986; Ciguel \& Aceñolaza, 1986; Carvalho \& Fernandes, 1989); e c) trabalhos de caráter conceitual, como os glossários e manuais de Campanha (1979) e Leonardi (1979; 1987), e uma das mais importantes fontes de informações é a bibliografia indexada da icnologia brasileira de Fernandes (1993).

A icnologia adentra o novo século, portanto, de perspectivas amplas. A sua aplicação é cada vez maior, seja por paleontólogos, seus principais divulgadores, seja por geólogos ou sedimentólogos que a utilizam como ferramenta para suas interpretaçðes. O crescente número de publicações em icnologia nas últimas décadas atesta a sua maturidade e a sua importância como ciência. 


\subsection{Icnofósseis vs. Fósseis Corpóreos}

Os icnofósseis representam registros importantes da presença e do comportamento de seres vivos do passado. $O$ aspecto etológico dos icnofósseis ocasiona algumas situações completamente distintas daquelas que ocorrem com os fósseis corpóreos, ou seja os fósseis representados por restos resistentes (conchas, dentes, ossos, troncos, etc.) e/ou moldes dos corpos dos organismos. Por exemplo, quanto ao modo de geração de icnofósseis, (Seilacher, 1964a; Bromley, 1990), um único organismo (ou uma única espécie), digamos um trilobita (Fig. 2.1), pode produzir diferentes estruturas de acordo com o seu comportamento perante as suas necessidades de alimentação, locomoção e descanso. Por outro lado, um mesmo icnofóssil pode ser gerado por organismos completamente diferentes, quando estes se comportam de maneira similar, como no caso de icnofósseis tubulares horizontais do tipo de Planolites e Palaeophycus. Outras estruturas podem resultar da ação de mais de um organismo, por comensalismo, tolerância à proximidade ou por ocupação de uma toca abandonada por organismos diferentes daqueles que as geraram. Também, o resultado final do comportamento de um organismo dependerá do tipo de substrato afetado, como no caso ilustrado na Figura 2.2. Desta forma, diferentes icnogêneros podem ser simplesmente o resultado de uma mesma ação efetuada sob diferentes condições estratinômicas.

Os principais aspectos que diferenciam os icnofósseis dos fósseis corpóreos quanto ao seu modo de preservação, segundo Basan, (1978b) e Carvalho \& Fernandes (2000), são: a) a ocorrência in situ dos icnofósseis, sendo representantes diretos de uma biocenose, enquanto os fósseis corpóreos são geralmente transportados representando uma tanatocenose; b) o registro dos icnofósseis ocorre principalmente em rochas clásticas (arenitos e siltitos), onde, muitas vezes, os fósseis corpóreos são menos comuns e em geral mal preservados; c) os processos diagenéticos que tendem a destruir o registro de fósseis corpóreos, geralmente tendem a salientar as características dos icnofósseis; d) os icnofósseis muitas vezes são abundantes em rochas que freqüentemente não apresentam fósseis corpóreos. 


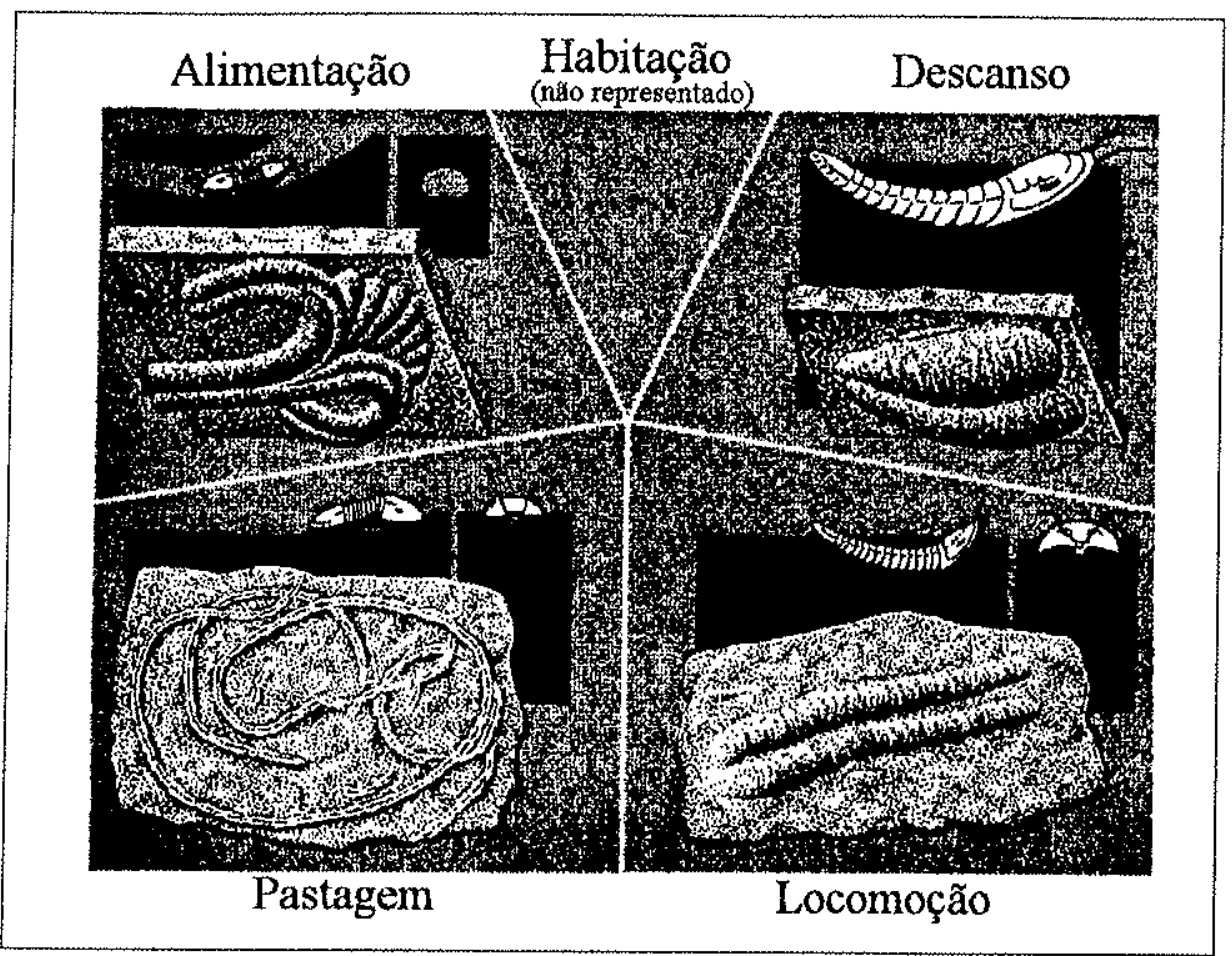

Figura 2.1 - Diferentes icnofósseis gerados de acordo com o comportamento diferenciado de um mesmo trilobita (Adaptado de Seilacher 1964b).

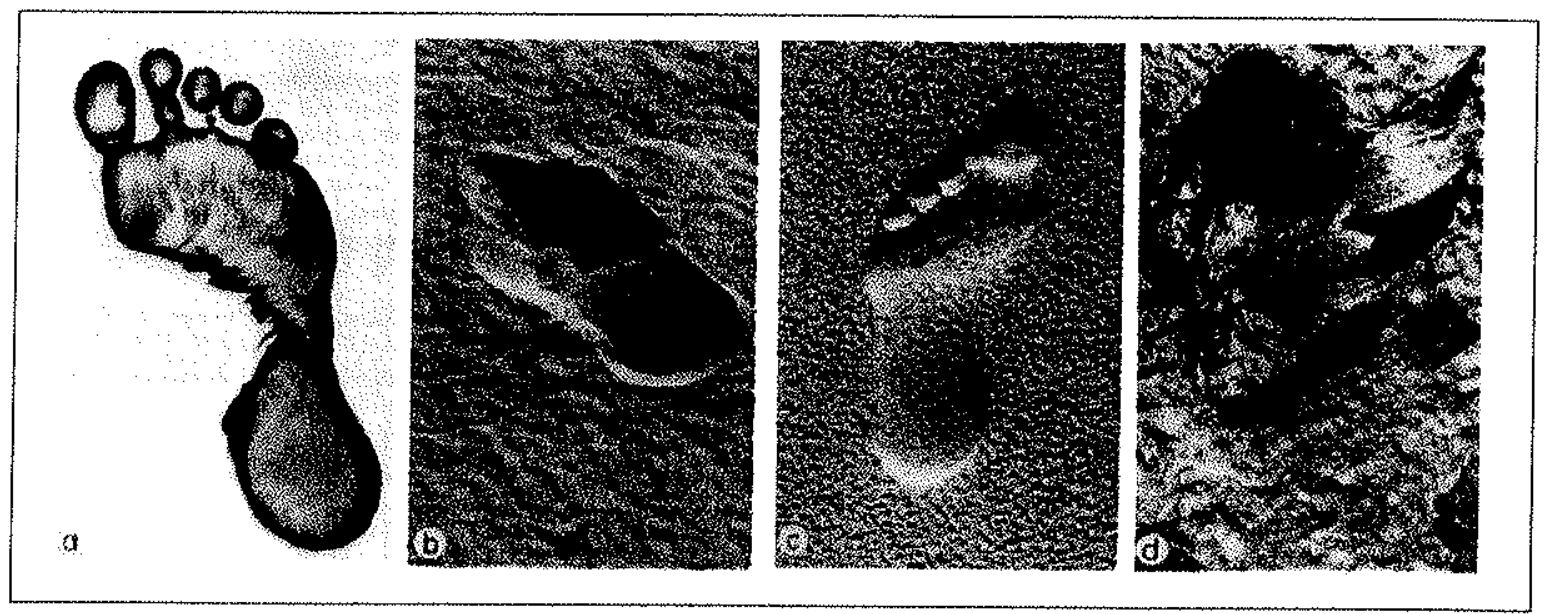

Figura 2.2 -Geração de pegadas humanas diferentes em diferentes substratos. a) em papel fotográfico; b) em areia seca; c) em areia molhada; e d) em lama. (Adaptado de Bromley 1990). 


\subsection{Importância dos Icnofósseis}

Diversos pesquisadores (Frey, 1973; Osgood, 1975b; Crimes, 1975; Rhoads, 1975; Howard, 1978; Basan, 1978a; Bromley, 1990; Lockley et al., 1994; Carvalho \& Fernandes, 2000) já ressaltaram a importância da paleoicnologia como ferramenta útil nas diferentes áreas da Geologia. Seilacher (1964b) assinalou quatro vantagens que fazem dos icnofósseis ferramentas geológicas:

a) Grande amplitude temporal - devido ao seu aspecto comportamental, vários icnogêneros ocorrem em mais de um período geológico, chegando a ocorrer em mais de uma era geológica (i.e. Planolites). Embora isto, possa restringir sua aplicação em bioestratigrafia, este fato permite comparações paleoecológicas e faciológicas de rochas que diferem muito em idade;

b) Estreita amplitude de fácies - um significante número de icnofósseis é restrito à um determinado tipo de fácies, independente do organismo gerador, refletindo a ação de resposta do organismo frente às condições do ambiente;

c) Ausência de deslocamento - ao contrário de outros fósseis, os icnofósseis normalmente não estão sujeitos ao transporte, sendo preservados in situ onde foram gerados;

d) Preferência por sedimentos clásticos - mesmo que os icnofósseis possam ocorrer em qualquer tipo de sedimento, eles são mais abundantes e melhor preservados em sedimentos clásticos, principalmente em camadas alternadas de areia e argila.

As principais contribuições da icnologia à geologia, segundo Frey (1973), são:

\section{Paleontologia}

A- registro fóssil de animais de corpo mole

B- evidência da atividade dos organismos

C- diversidade da assembléia fossilífera

D- evolução dos metazoários e do seu comportamento 


\section{Estratigrafia}
A- bioestratigrafia de rochas "afossilíferas"
B- correlação por marcadores de camada
C- atitude estrutural das camadas
D- deformação estrutural dos sedimentos

3. Sedimentologia

A- produção de sedimentos por organismos escavados

B- alteração dos grãos por organismos detritívoros

C- retrabalhamento dos sedimentos:

1. destruição da fabrica inicial e estruturas sedimentares

2. criação de nova fábrica e novas estruturas sedimentares.

4.Ambientes deposicionais e paleoecologia
A- batimetria
B- temperatura e salinidade
C- história deposicional
1. taxas de deposição
2. quantidade de sedimentos depositados ou erodidos
D- aeração da água e dos sedimentos
E- coerência e estabilidade do substrato

\section{Consolidação dos sedimentos}

A- história inicial da litificação

B- mensuração da compactação

Os icnofósseis tem importância especial no estudo do comportamento dos organismos, tanto fósseis como recentes. $\mathrm{O}$ estudo do comportamento de animais extintos muitas vezes só é possivel graças a paleoicnologia. No entanto a relação da paleoicnologia com o estudo do comportamento de animais recentes é um pouco menos direta. Esta relação se baseia no 
principio do "uniformitarismo reverso" (Frey, 1973), ou seja "do passado como chave para o presente" (Frey \& Seilacher, 1980). O estudo dos icnitos do passado permite, por exemplo, que biólogos tenham acesso a informaçôes sobre o comportamento animal em ambientes de dificil acesso hoje em dia, como, por exemplo, no subsolo oceânico abissal.

O estudo e a identificação de paleoambientes também são favorecidos pela análise dos icnofósseis, pois os tipos e a diversidade dos icnitos variam com as condições ambientais. Estas relações permitiram o desenvolvimento do conceito de icnofácies (Seilacher, 1967a, 1967b). O esquema original de Seilacher (op. cit.) para icnofácies marinhas estabeleceu as associações dentre seis icnofácies, cada qual designada pelo nome genérico de um de seus icnofósseis mais característicos, ou seja, as icnofácies de Trypanites, Glossifungites, Skolithos, Cruziana, Zoophycus, e Nereites. Atualmente, reconheceram-se outras cinco icnofácies, totalizando onze. Em ambiente continental encontram-se as icnofácies de Scoyenia, Termitichnus, Mermia, e Psilonichnus, e em ambiente marinho, as icnofácies Trypanites, Glossifungites, Skolithos, Cruziana, Zoophycus, Nereites, e Teredolites (Carvalho \& Fernandes, 2000). A figura 2.3 mostra esquematicamente a distribuição das icnofácies marinhas, mais a icnofácies de Psilonichnus, de pós-praia e dunas litorâneas.

O Brasil tem um excepcional potencial de utilização da icnologia. Diversos são os registros de bioturbação (ver Fernandes, 1993), em rochas das mais diversificadas idades e de vários ambientes. Inclusive sequiências potencialmente fossiliferas da transição PréCambriano/Cambriano (e.g. Grupo Corumbá), onde o estudo dos icnofósseis tem papel fundamental. 


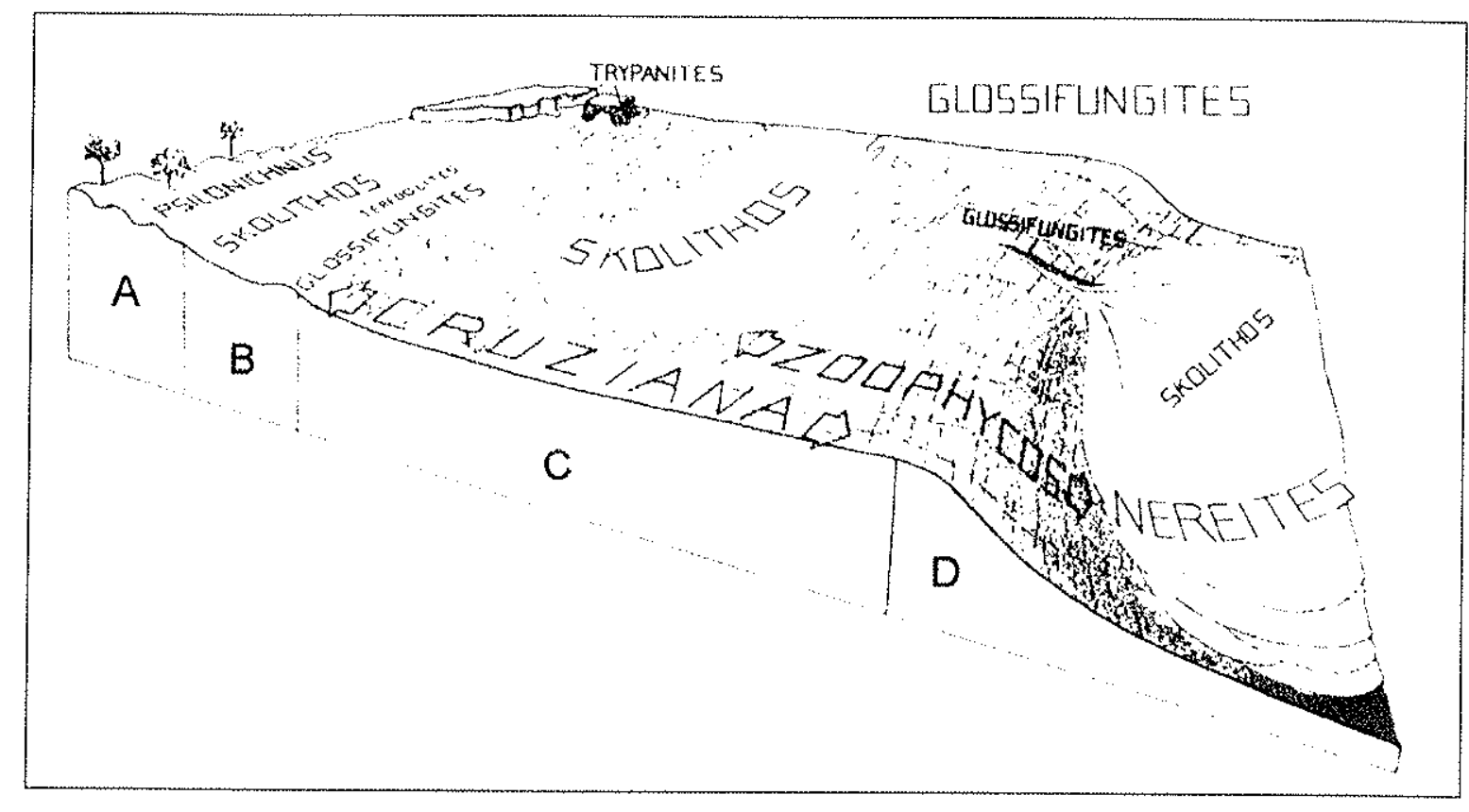

Figura 2.3-Distribuição esquemática das icnofácies em um ambiente marinho. A-Pós-praia e dunas litorâneas; B- Região litorânea de baixa energia; C- Região de baixa energia e da plataforma; D- Região do talude e zonas abissal e batial. (Modificado de Pemberton et al., 1990). 


\section{A Caracterização e Classificação de Icnofósseis}

\subsection{Caracterização de Icnofósseis}

A análise de um objeto cuja origem pode ser biológica pode levar a uma das três conclusões seguintes: a) o objeto é de origem biológica (ou biogênica); b) o objeto não é de origem biológica; e c) com os dados disponíveis, não é possível identificar com precisão a sua origem. No primeiro caso o objeto é classificado como icnofóssil (cujo conceito já foi discutido no capitulo anterior). No segundo caso o objeto é classificado como pseudofóssil - um objeto natural, não biogênico, que se assemelha e pode ser confundido com um fóssil (Schopf, 1983). E, no terceiro caso, o objeto é classificado como dubiofóssil --. um objeto ou uma estrutura de possível, mas ainda não estabelecida, origem biogênica; os objetos são atribuidos a esta categoria temporariamente, até que informações adicionais possam permitir a sua classificação como fósseis ou pseudofósseis (Schopf, op. cit.).

Os diversos critérios para a caracterização de um objeto como de origem biogênica, ou não, foram sintetizados por Ekdale et al. (1984) e Pickerill (1994). Estes critérios representam indicios fortes da origem de um objeto, embora nem sempre sejam conclusivos quando analisados isoladamente. Segue abaixo um resumo destes critérios:

Critérios que indicam uma origem biogênica:

a) Tamanho elou continuidade uniforme de uma estrutura individual -Por serem gerados pela ação de um organismo de tamanho e forma normalmente bem delimitados, os icnitos individuais tipicamente apresentam um padrão uniforme de tamanho e continuidade, sem variações bruscas.

b) Forma geométrica regular, complexa e repetitiva -Este critério diz respeito ao resultado de ações especificas algo mais complexas do que aqueles representados no critério (a), acima. No entanto, a aplicação deste critério deve ser cuidadosa, pois algumas exceções são conhecidas. Por exemplo, o re-estudo feito por Seilacher et 
al. (2000) do "fóssil" pré-cambriano Vermiforma antiqua Cloud 1976, de formato complexo, regular e repetitivo, revelou que a regularidade dos espécimes excedia qualquer outro padrão de regularidade já conhecido em icnitos. Por meio de uma série de testes em laboratório, Seilacher et al. (op. cit.) comprovaram que o padrão morfológico e a orientação destas marcas, idênticos em toda a amostra, eram de origem tectônica. Propuseram para esta nova classe de pseudofóssil o termo "tectograph" - traduzido aqui como tectógrafo.

c) Presença de revestimento ("lining") ou estrutura de parede - Um tubo, ou outra marca no sedimento definido pela presença de um revestimento ou de uma parede (afastado, naturalmente, qualquer possibilidade de origem puramente química), pode ser indicativo de origem biogênica, pois em ambos os casos é necessário a presença de um organismo para gerar estas feições.

d) Laminação do tipo Spreite (em forma de meniscos ou U) -- Utiliza-se o termo Spreite (do alemão; Spreiten, plural) para descrever a laminação curva, lembrando a forma de menisco, produzidos por diversos organismos-Spreiten podem se formar de três maneiras, todas de origem biológica (Bromley, 1990): pelo movimento de um organismo detritívoro em busca de alimento, resultando no deslocamento parcial de sua toca; pelo deslocamento, no plano vertical, de um organismo no sedimento em função de flutuações (erosão, sedimentação) da interface sedimento/água; e por uma sucessão de colapsos gravitacionais e reparos das margens da toca de um organismo, resultando na formação de camadas laminadas em U. Figura 4.14 ilustra estes tipos.

e) Presença de pellets fecais ou resíduos orgânicos -Embora pellets fecais e resíduos orgânicos não se preservem freqüentemente, quando encontrados são evidências importantes da origem biogênica do objeto. Contudo, a presença de pellets, mesmo sendo uma boa evidência de biogenicidade, deve ser analisada levando-se em consideração a possibilidade dos objetos terem sido transportados e depositados distantes do local de sua origem.

f) Presença de estruturas morfológicas muito delicadas - Estruturas muito delicadas não tem condições de serem geradas por processos não biogênicos. 
g) Preservação em relevo completo - Um objeto preservado em relevo completo (estruturas discretas encontradas inteiras, geralmente dentro das camadas, ou nas interfaces entre camadas) é produzido por processos biogênicos. Alguns processos abiogênicos podem eventualmente gerar estruturas cuja preservação seja similar a de relevo completo (i.e. vulcões de areia). No entanto, sua ocorrência é rara..

h) Restos corpóreos em associação direta com o suposto icnofóssil - Embora muito rara, a preservação dos restos de um organismo em contato direto (e não casual) com um possível icnito constitui forte evidência de sua biogenicidade (Fig. 3.1)

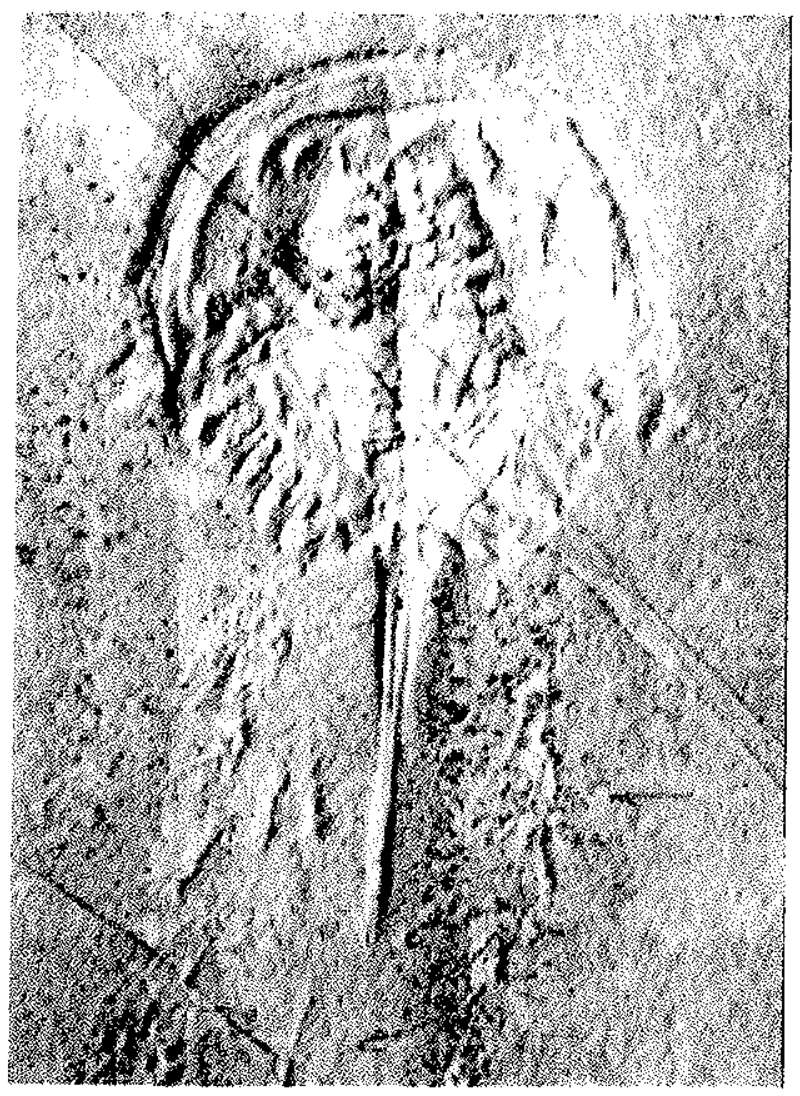

Figura 3.1 - Preservação rara, do organismo gerador junto aos icnitos produzidos por ele (Extraída de Häntzschel, 1975). 
Critérios que indicam uma origem não biogênica:

a) Semelhança com uma estrutura sedimentar inorgânica primária ou com estrutura diagenética secundária - Ainda que alguns icnitos verdadeiros possam se assemelhar a estruturas sedimentares primárias ou diagenéticas abiogênicas, esta semellança deverá ser considerada, a princípio, como mais coerente com uma origem abiogênica do que biogênica.

b) Dimensões variáveis ou adelgadas -Uma estrutura produzida por um organismo nos sedimentos deve ter dimensões pouco variáveis. Em geral a morfologia de um organismo não é variável. Desta forma os objetos produzidos por ele não devem apresentar dimensões oscilantes entre grossa e fina, estreita e larga ou ampla e adelgaçada. Algumas vezes, porém, variações nas dimensões aparentes podem resultar do deslocamento tortuoso do organismo para dentro e fora do substrato.

c) Tamanho elou forma não uniforme do conjunto de estruturas - Um organismo realizando uma mesma ação, em um mesmo substrato, deve produzir icnitos semelhantes em tamanho e forma. Quando se analisa um conjunto de objetos de tamanho e/ou forma não uniformes, e descartando a possibilidade destas diferenças terem sido produzidas por individuos de espécies ou idades diferentes, pode-se considerar este fator como critério de origem abiogênica.

d) Padrão geométrico irregular - Como os icnitos são o reflexo do comportamento dos organismos, un organismo, repetindo um mesmo comportamento, deve apresentar um padrão geométrico regular. Assim, padrões pouco regulares são mais sugestivos de origem abiogênica.

e) Orientação preferencial estrita - Uma orientação preferencial estrita é geralmente indicador da atuação de agentes abiogênicos externos, por exemplo esforços tectônicos ou fluxos sedimentares, na formação de estruturas em rochas.

f) Substituição mineral óbvia - Embora vários icnofósseis são associados com mineralização secundária, é a morfologia da estrutura que deve ser considerada. Massas amorfas, faces cristalinas distintas, bandeamento de discordante de cores, associação com fraturas ou juntas, ocorrência em estilólitos ou outras feições de dissolução, etc., são indícios de estruturas de origem abiogênicas. 
Utilizando critérios como os acima, Hofmann (1971) propôs uma escala numérica variando de inorgânico (1) a orgânico (5), para caracterizar supostos icnitos. A escala proposta no presente trabalho será mais ampla para permitir um resultado mais refinado. Esta escala, denominada de índice de biogenicidade, vai de um a sete, cada número correspondendo a um grau de definição dos objetos quanto à sua origem:

\section{1-Abiogênico ou Pseudofóssil}

2-Provavelmente Abiogênico

3-Possivelmente Abiogênico

4-Dubiofóssil

5-Possivelmente Biogênico

6-Provavelmente Biogênico

7-Biogênico ou Icnofóssil

Ainda que bastante subjetiva, esta escala permite uma maior flexibilidade de classificação, especialmente em casos de insuficiência de: informações sobre os espécimes ou o contexto geológico; falta de material para comparação; exemplares únicos ou poucos exemplares; espécimes incompletos ou perdidos; ou preservação aquém do desejável.

\subsection{Classificação de icnofósseis}

Os icnofósseis podem ser descritos e classificados, utilizando-se diferentes enfoques. Seilacher (1964a) separou os icnofósseis de acordo com seus aspectos taxonômicos, comportamentais e preservacionais. Estes aspectos, embora distintos, são complementares. Pode-se classificar um icnofóssil quanto a sua taxonomia, quanto ao seu modo de preservação e quanto ao comportamento do organismo que o gerou. 


\subsubsection{Classificação taxonômica}

Os icnofósseis, em decorrência das características peculiares de sua formação, descritas no capítulo anterior, raramente podem ser atribuídos à ação de um organismo ou um grupo taxonômico específico, com exceção de algumas pistas raras de artrópodes e vertebrados. Assim, sem possibilidades reais de estabelecer relações entre icnitos e os grupos biológicos responsáveis por sua formação, os estudiosos neste campo desenvolveram sua própria classificação taxonômica, aproveitando-se da sistemática linneana.

A sistemática dos icnofósseis (nomenclatura e taxonomia) ainda apresenta alguns problemas. Parte destes problemas foi gerado pela descrição e interpretação de vários icnofósseis como os próprios fósseis corpóreos de animais e plantas. Chondrites von Sternberg, 1833, e Cruziana d'Orbigny 1842, foram primeiramente descritos como de origem vegetal; o sufixo - phycus, presente em grande número de icnotáxons, é originário da descrição deste icnofósseis como fucóides, também de origem algácea; e Nereites MacLeay, 1839, foi primeiramente descrito como um "verme".

Outros problemas resultaram da ausência, por muito tempo, de um código de nomenclatura claro e amplamente adotado (Pickerill, 1994). Para complicar a situação ainda mais, no XV Congresso Internacional de Zoologia, em 1961, a Comissão Internacional de Nomenclatura Zoológica (CINZ) decidiu que os nomes dos icnofósseis descritos após 1930 não mais estariam disponíveis, devendo ser tratados como vernáculos, não mais governados pelas regras de prioridade ditađas pelo Código Internacional de Nomenclatura Zoológica. No entanto, os nomes aplicados antes de 1931 permaneceram disponíveis para utilização de acordo com as regras do CINZ (Basan, 1979; Pickerill, 1994). Esta decisão não foi aceita pelos icnólogos, que continuaram a aplicar as regras do Código Internacional de Nomenclatura Zoológica aos icnofósseis, apesar da proibição (Bromley, 1990; Pickerill, op. cit.).

Nos anos seguintes, várias foram as propostas de mudança na nomenclatura dos icnofósseis. Häntzschel \& Kraus (1972) propuseram emendas ao código para a Comissão 
de Nomenclatura Zoológica. Sarjeant \& Kennedy (1973) sugeriram um código próprio para a nomenclatura de icnofósseis, utilizando parte das regras do Código Internacional de Nomenclatura Zoológica e incorporando a linguagem do Código Internacional de Nomenclatura Botânica. Este código foi posteriormente revisado pelo grupo de pesquisa de icnofósseis da SEPM ("SEPM Trace Fossils Research Group") em 1976 (Basan, 1979), e revisado novamente por Sarjeant em 1979. O problema de nomenclatura só foi solucionado em 1985, com o cancelamento, pelo Código Internacional de Nomenclatura Zoológica, das restrições impostas em 1961 em relação aos icnofósseis descritos depois de 1930. Os artigos mais relevantes deste código para a icnologia são os artigos $1 \mathrm{~d}, 2 \mathrm{~b}, 10 \mathrm{~d}, 13 \mathrm{~b}, 23 \mathrm{~g}$, $42 \mathrm{~b}(\mathrm{i}), 66, \mathrm{e} 67 \mathrm{~m}$.

Ainda ocorrem problemas relativos à falta de algumas diretrizes normativas na nomenclatura dos icnofósseis. Novos nomes são aplicados às vezes sem nenhum padrão, ao bel-prazer do descritor do espécime, como, por exemplo, a atribuição, por um entusiasta de motocicletas, do nome Hondichnus isp. (Ausich, 1979) a uma pista. Idealmente, deve-se levar em consideração que a morfologia do espécime é uma expressão de seu comportamento, e deve-se utiliza-la como base para o seu nome. Porém, isto não impede, infelizmente, distorções na nomenclatura de icnofósseis geradas pela interpretação da estrutura pelo seu descobridor (Bromley, 1990).

A proposta de Fürsich $(1974 a, 1974 b)$ da utilização do conceito de feições significativas e acessórias na nomenclatura de icnofósseis foi um importante passo no direcionamento da sistemática dos icnofósseis, embora ainda não seja amplamente aceita. Esta proposta está baseada no uso de feições morfológicas de comportamento para a nomenclatura de icnofósseis, utilizando-se das feições significativas para icnogênero e acessórias para icnoespécie.

Bromley (1990) reconheceu quatro critérios importantes para a base da nomenclatura dos icnofósseis: forma geral; tipo de estrutura de parede (se presente); tipo de ramificação (se presente); e natureza do preenchimento, explicados abaixo. 
Forma geral - Este critério considera o formato do objeto e sua orientação. Em geral, seu tamanho não é considerado importante.

Estrutura de parede - Bromley (1990) reconhece sete principais tipos de estrutura de parede: a) sem estrutura; b) película de poeira (dust film); c) parede construída (constructional walling); preenchimento zonado (zoned fill); e) parede compactada (wall compactation); f) halos diagenéticos (diagenetic halos); e g) parede ornamentada (ornament wall).

Ramificação - Os diferentes tipos de ramificação, bem como sua ausência, estão diretamente relacionados com o comportamento do animal, sendo de grande importância na nomenclatura da estrutura. D'Alessandro \& Bromley (1987) classificam as ramificações em: a) falsa; b) secundária sucessiva; c) primária sucessiva; e d) simultânea, conforme Fig. 3.2 .
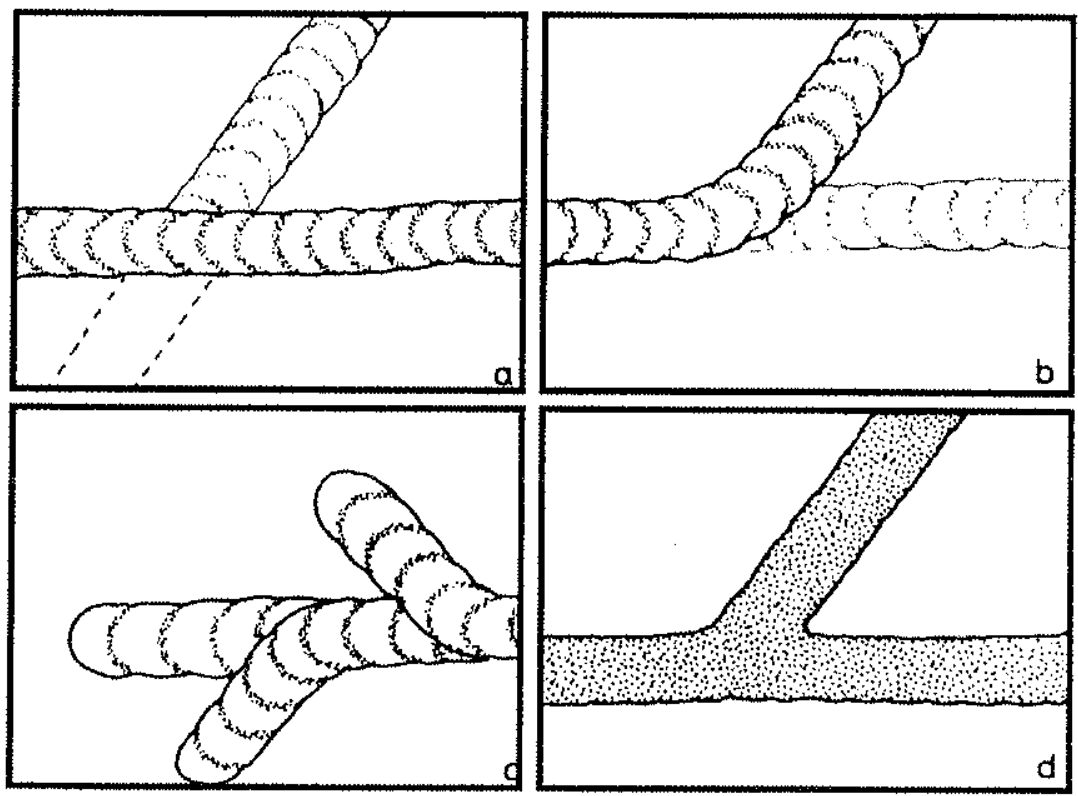

Figura 3.2 - Classificação das ramificações segundo D’Alessandro \& Bromley (1987): falsa (a); secundária sucessiva (b); primária sucessiva (c); e simultânea (d). (modificada de Bromley, 1990) 
Preenchimento - O material de preenchimento pode ser igual ou diferente ao sedimento ao redor do icnito, enquanto o processo de preenchimento pode ser passivo (gravitacional) ou ativo (preenchido pelo organismo).

\subsubsection{Classificação dos icnofósseis de acordo com sua forma preservacional}

Os icnofósseis podem ser considerados como estruturas sedimentares e classificados conforme seu modo de preservação. Vários autores (e.g. Ekdale et al., 1984; Frey \& Pemberton, 1985) têm proposto termos e classificações para estas possibilidades estratinômicas. Neste trabalho serão utilizadas as propostas de Seilacher (1964a), que trata os icnofósseis de acordo com o seu relevo, e de Martinsson $(1965,1970)$, que classifica os icnofósseis em relação à sua posição dentro da camada. Em ambas as propostas são adotados os prefixos epi-, para objetos evidentes na superfície superior da camada, e hipo-, para objetos relacionados à superficie inferior. Bromley (1990) compara estas propostas graficamente, conforme Figura 3.3.

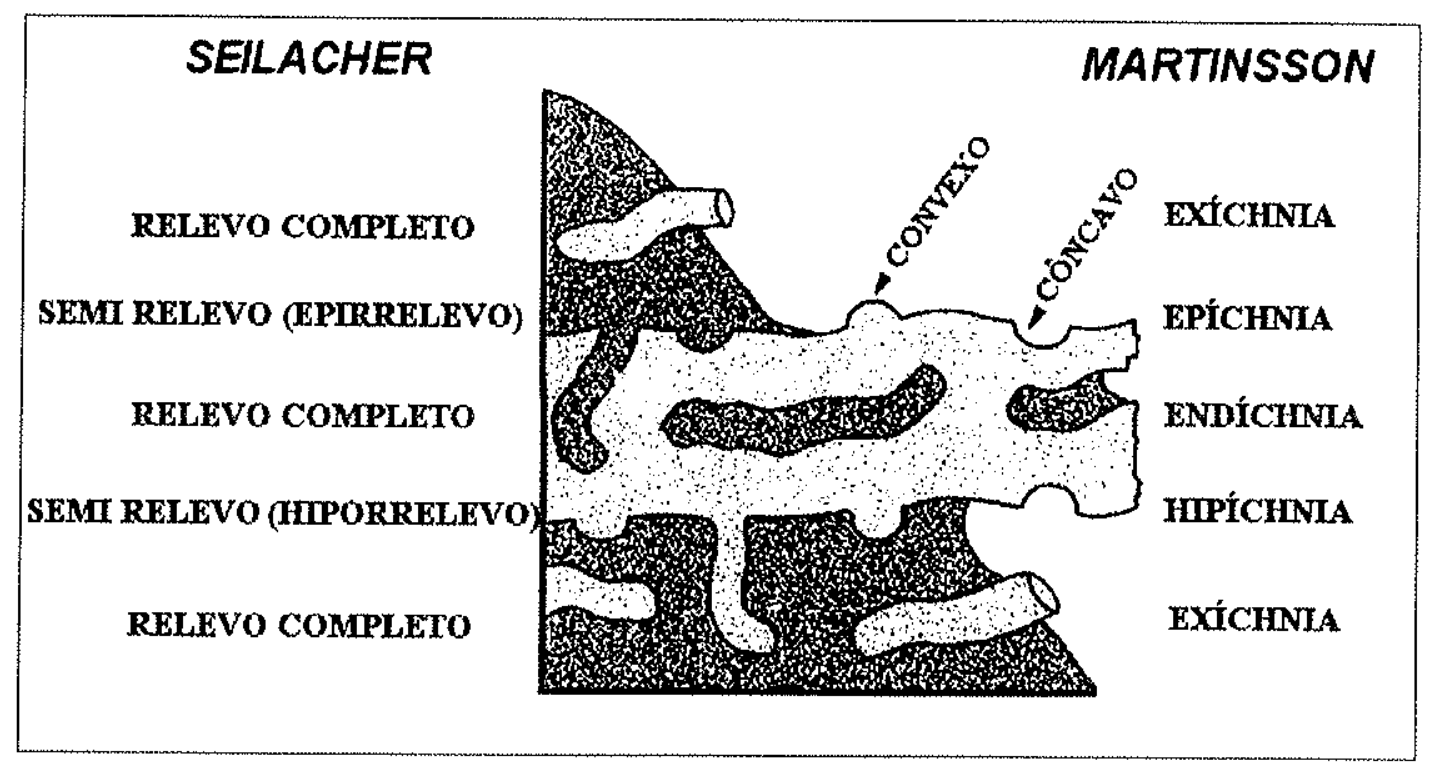

Figura 3.3 - Comparação dos conceitos e terminologia nas classificações preservacionais de Seilacher (1964a) e Martinsson (1965 e 1970), segundo Bromley (1990). 
A classiffcação de Seilacher (1964a) descreve o relevo do icnofóssil, distinguindo semirelevos e relevos completos. Os semi-relevos ocorrem na interface areia/argila ou nas interfaces entre litologias similares. São designados, conforme sua posição dentro da camada, em epirrelevos, no topo, e hiporrelevos na base, sendo complementados quanto à sua forma, pelos adjetivos côncavo ou convexo. Os relevos completos são estruturas discretas encontradas inteiras, geralmente dentro das camadas, ou na interface entre camadas. Relevos completos podem ocorrer na forma de preenchimentos (do mesmo material do sedimento ou de material distinto) ou de cavidades.

Seilacher (1964b) inclui em sua classificação os termos sugeridos pelo Comitê de Nomenclatura de Estruturas Sedimentares (Figura 3.4): a) exógeno, para pistas na superfície; b) endógeno, para moldes primários; c) pseudoexógeno, para moldes secundários; d) preenchimento ativo para icnitos preenchidos pelo próprio organismo; e) preenchimento passivo para icnitos preenchidos pela sedimentação.

A classificação de Martinsson (1970) é baseada na posição do icnofóssil em relação à camada em estudo. Quando os icnofósseis localizam-se dentro da camada são chamados de endícnios (Endichnia), quando são externos à camada são exícnios (Exichnia). Se encontrados na superfície superior da camada são epícnios (Epichnia), se na superficie inferior são hipícnios (Hypichnia). 


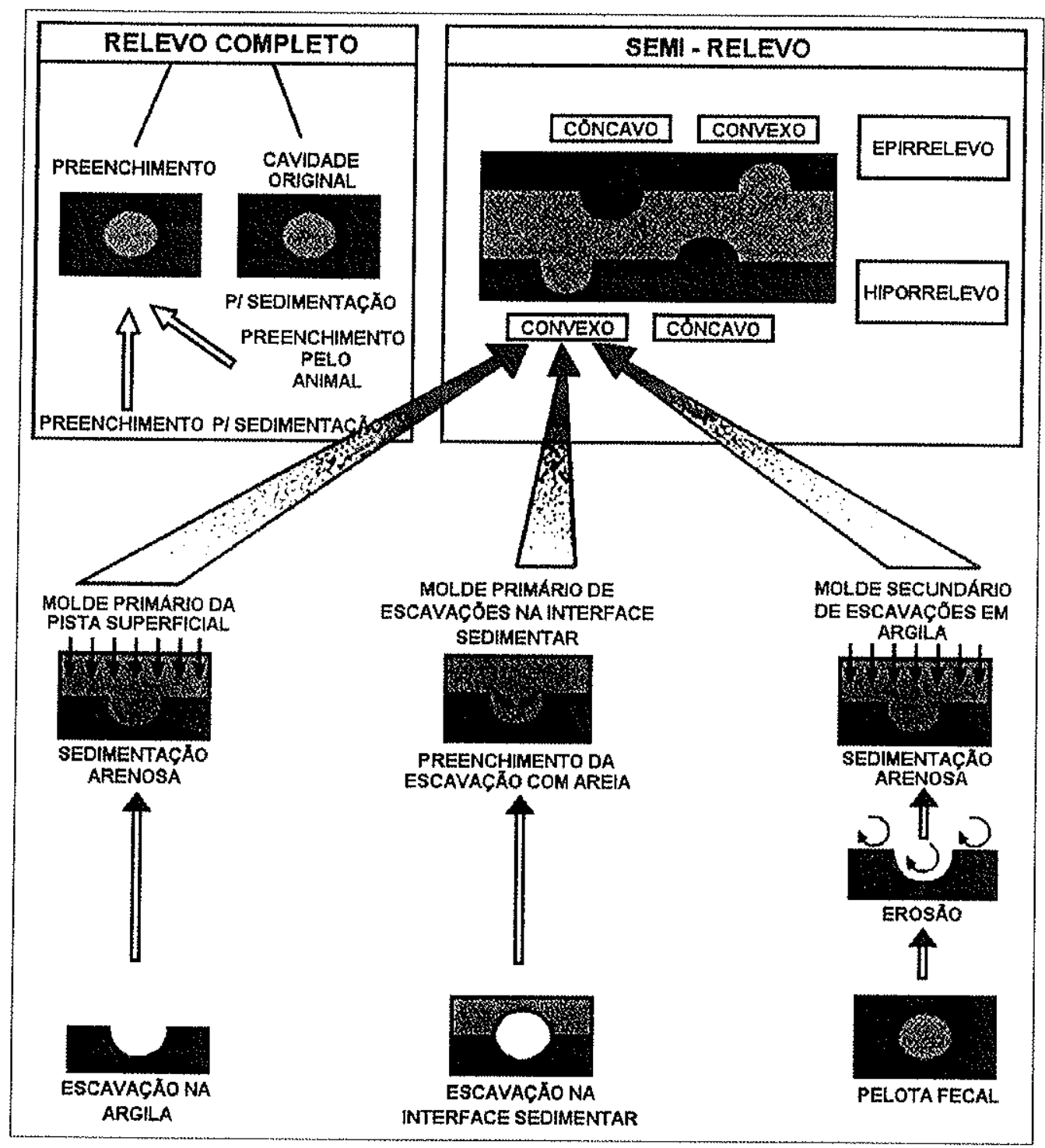

Figura 3.4 -- Classificação preservacional e processo de geração de icnofósseis (Extraída de Carvalho e Fernandes 2000, original de Seilacher 1964b).

Além das classificações de Seilacher (1964a e 1964b) e Martinsson (1965 e 1970), outras duas propostas abordam a questão da classificação preservacional, uma de Simpson (1957) e outra de Chamberlain (1971). O esquema de Simpson (op. cit.) enfatiza quatro estilos diferentes de preservação de icnitos: a) preservação diagenética (diagenetic preservation) para icnitos realçados ou preservados por processos diagenéticos, tais como compactação, dissolução diferenciada, concrecionamento preferencial, etc.; b) preservação por junção de estratos (bed junction preservation) para icnitos preenchidos por sedimento, 
litologicamente distinto da camada em que ocorrem, infiltrado da base da camada sobrejacente de modo que o icnito parece uma extensão para baixo desta camada; c) preservação interfacial críptica (concealed bed junction preservation) para icnitos preenchidos como em $\underline{b}$ mas com a remoção da camada originária do preenchimento e a retomada da sedimentação original, deixando o icnito com aspecto isolado na sucessão; e d) preservação por exumação (burial preservation) para icnitos já preenchidos exumados em função da erosão diferenciada da matriz original e rapidamente recoberto por novos sedimentos. Chamberlain (1971) distingue três estilos de formação: a) epigênico, à superfície dos sedimentos; endogênico, dentro dos sedimentos, e c) intergênico, para icnitos formados na interface de camadas distintas. Uma síntese destas propostas pode ser vista na Figura 3.5 .

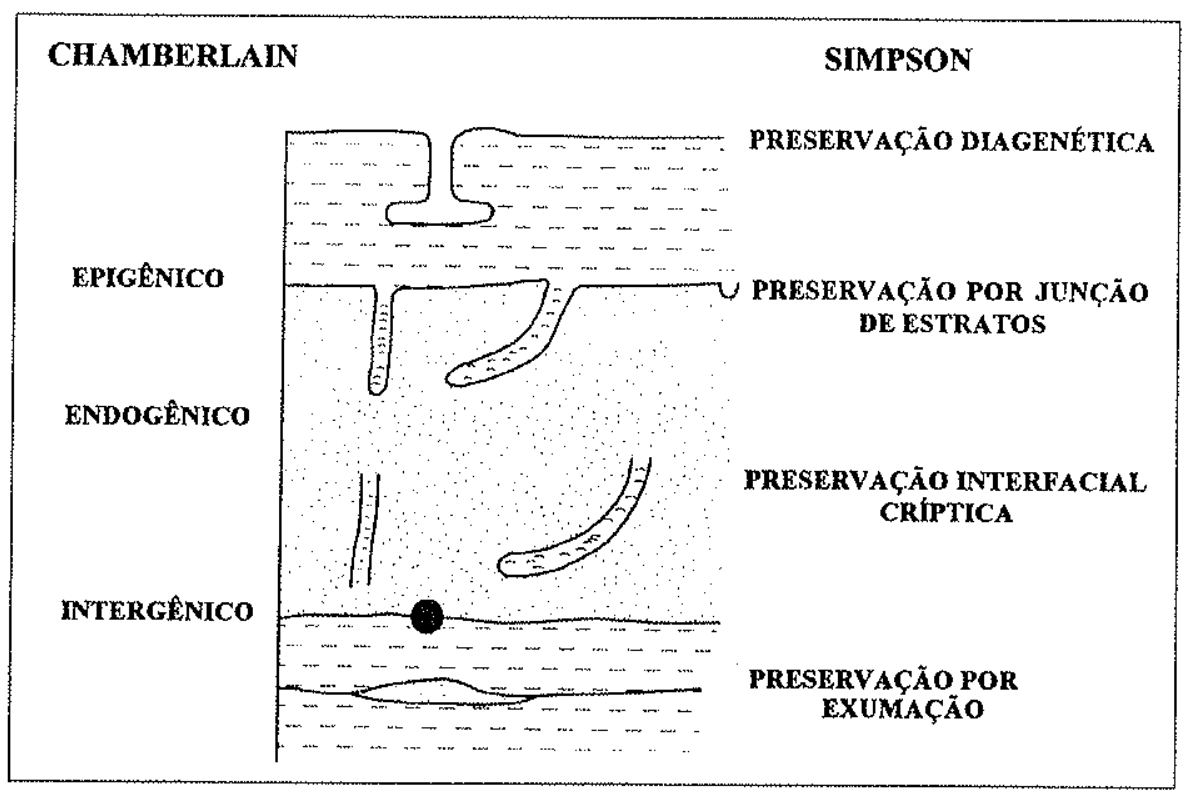

Figura 3.5 - Comparação dos conceitos e terminologia nas classificações preservacionais de Chamberlain (1971) e Simpson (1957). (Modificada de Pemberton, 1992). 


\subsubsection{Classificação Etológica dos Icnofósseis}

Os icnofósseis também podem ser tratados como registros de tipos e aspectos do comportamento de organismos. Desta forma, os icnofósseis podem ser diferenciados de acordo com a sua finalidade biológica. Novamente, foi Seilacher (1953) que estabeleceu o esquema básico, ainda em uso hoje. Segundo ele, os icnitos podem representar: Locomoção (Repichnia); Habitação (Domichnia); Descanso (Cubichnia); Alimentação (Fodinichnia); e Pastagem (Pascichnia) (Figura 3.6). A esta classificação foram acrescentados os conceitos de icnitos de: Escape (Fugichnia) (Osgood, 1970); Cultivo ou Armadilha (Agrichnia) (Ekdale et al., 1984), Predação (Praedichnia) (Ekdale, 1985); Equilibrio (Equilibrichnia) (Bromley, 1990); Morte (Taphichnia) e Pseudoicnitos (Pseudichnia) (Frey et al., 1987) (Figura 3.7).

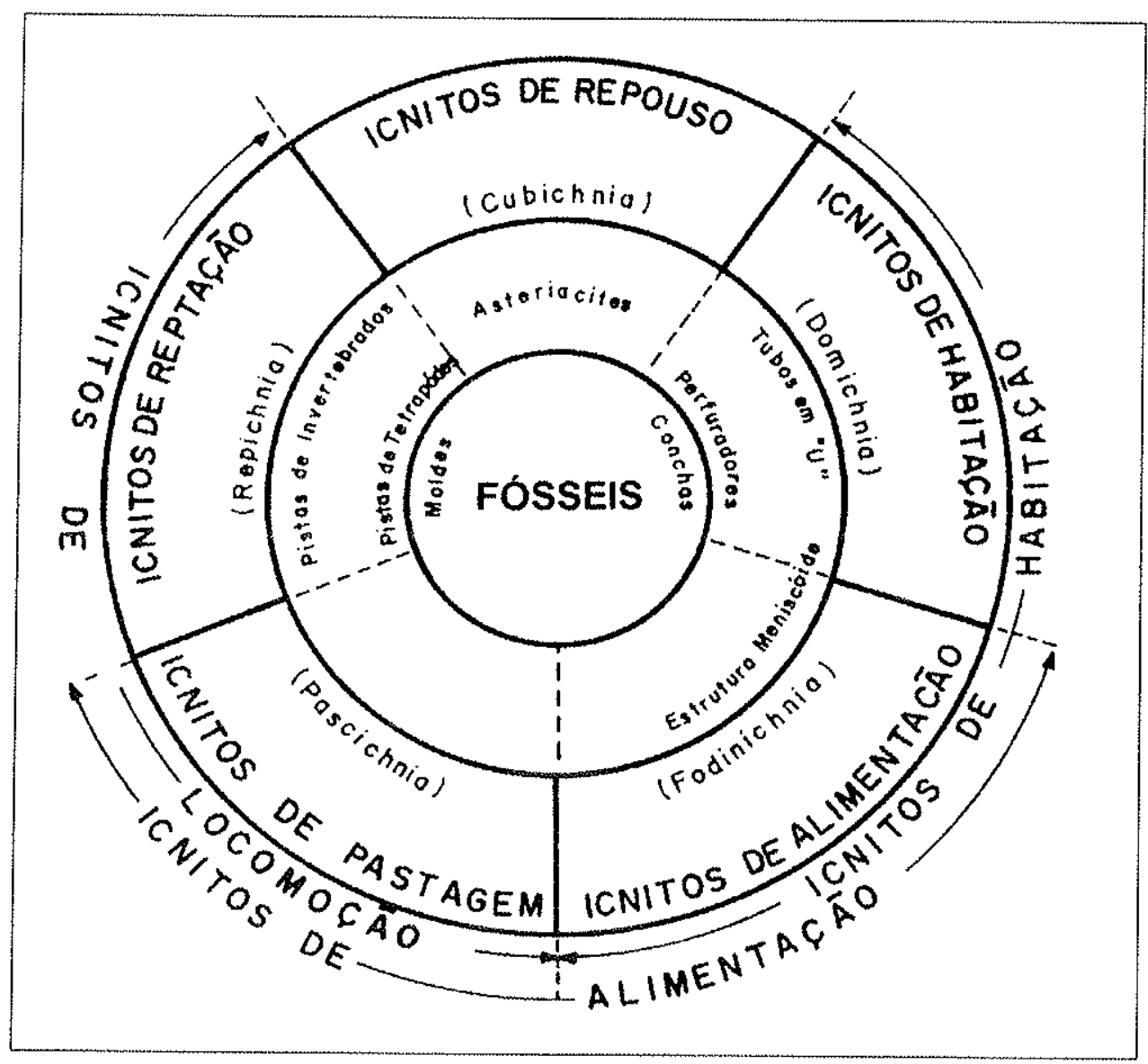

Figura 3.6 - Classificação etológica dos icnofósseis. (Extraída de Carvalho \& Fernandes, 2000. Original de Seilacher, 1953). 


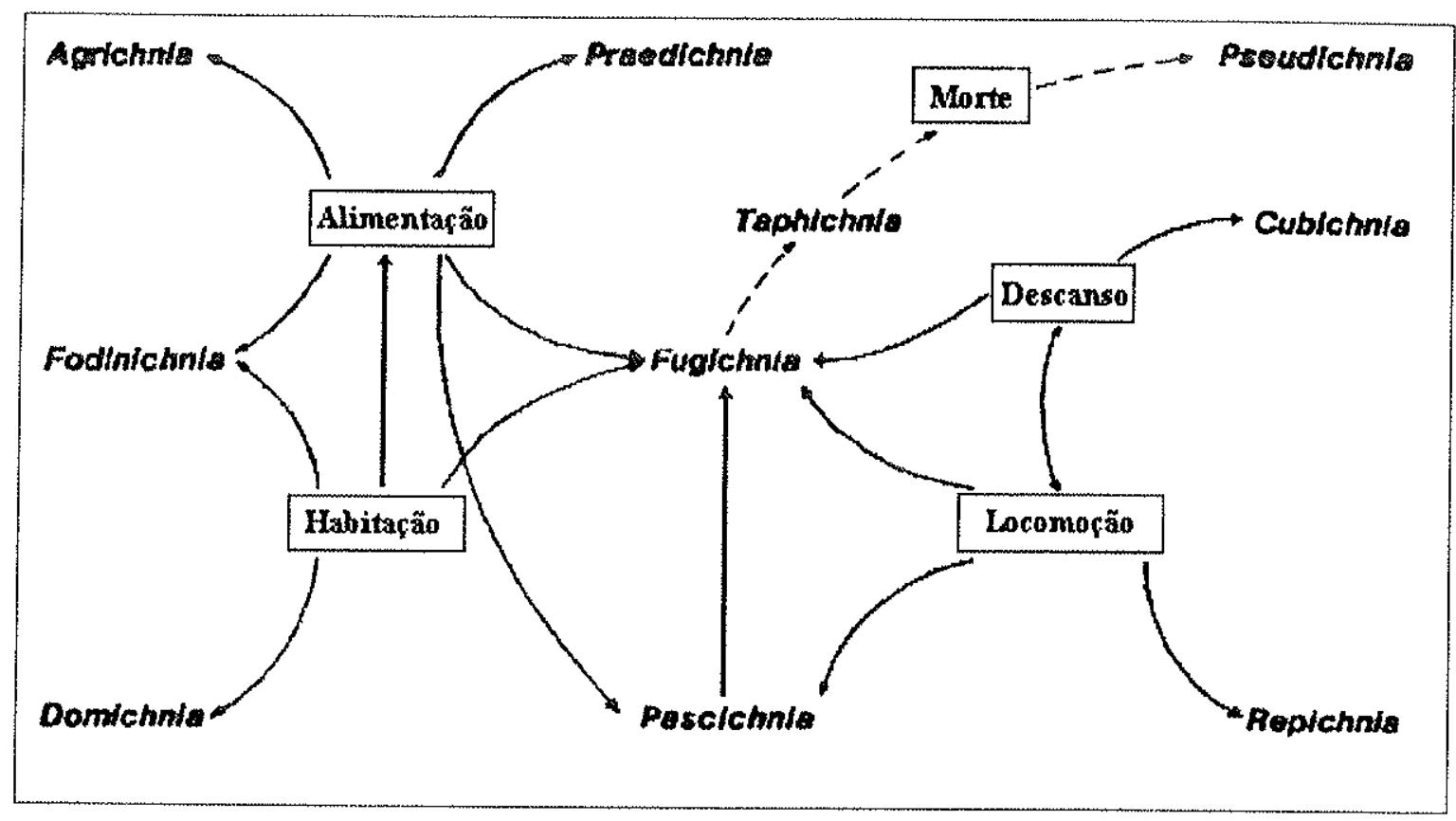

Figura 3.7 - Classificação etológica dos icnitos (Frey et al., 1987).

Icnitos de Locomoção (Repichnia) - Evidências da locomoção do organismo entre dois ou mais locais, não apresentando indícios de nenhuma outra atividade (i.e. Diplichnites).

Icnitos de Habitação (Domichnia) - Estruturas de habitação permanentes ou semipermanentes (i.e. Skolithos).

Icnitos de Descanso (Cubichnia) - Embora considerados de descanso, a maioria destes icnitos representam marcas de animais que se alimentam estacionariamente (ou seja ficam em posição de repouso), mas que podem migrar para novos locais para se alimentar. Poucos são os traços considerados efetivamente como de descanso (i.e. Lockeia, Rusophycus).

Icnitos de Alimentação (Fodinichnia) - Evidências da movimentação de animais detritívoros em busca de alimento no substrato (i.e. Chondrites).

Icnitos de Pastagem (Pascichnia) -.- Traços espirais ou meandrantes, demonstrando comportamento sistemático do animal em busca de alimentação em um determinada área do substrato (i.e. Nereites). 
Icnitos de Escape (Fugichnia) - Estruturas de escape de animais submetidos a soterramento rápido ou perseguidos por predadores.

Icnitos de Cultivo ou Armadilha (Agrichnia) - Estruturas complexas que representam armadilhas para captura de alimento (i.e. Spirorhaphe e Cosmorhaphe) ou para cultivo, por exemplo de micróbios, para alimentação (i.e. Paleodictyon e Helicolithes).

Icnitos de Predação (Praedichnia) - Estruturas que evidenciam comportamento predatório. Sua representação mais típica é a de orificios circulares feitos por estrelas-do-mar em conchas de molusco. São de difícil reconhecimento em substratos moles (i.e. Oichnus simplex).

Icnitos de Equilibrio (Equilibrichnia) - Traços indicativos de ajuste na posição de animais da infauna, para manter contato com a superficie, variando de acordo com mudanças no nível da água e no aporte de sedimentos.

Icnitos de Morte (Taphichnia) - Estruturas que representam a morte ou os movimentos finais do animal, podendo incluir também marcas feitas pelo movimento involuntário ou pelo transporte da carcaça do animal.

Pseudoicnitos (Pseudichnia) - Estruturas que lembram icnitos, mas são de origem não biogênica: Entretanto, a utilização de um termo classificatório para objetos de comprovada origem inorgânica é no mínimo questionável e provavelmente dispensável, pois se o objeto não é um icnofóssil, não deve ser adicionado a uma classificação que trata somente de icnofósseis.

Nem todos os pesquisadores utilizam a terminologia da classificação etológica com o mesmo sentido. Em alguns casos, inclusive, a proliferação dos termos acaba gerando divergências em sua interpretação e aplicabilidade. Osgood (1970) e Bromley (1990) 
classificam como Fugichnia, por exemplo, os icnitos de escape, enquanto Pemberton et al. (1992) agrupam nesta mesma categoria os icnitos de escape e de equilibrio.

Analisados criticamente, os termos mais novos, apesar de aplicáveis, podem ser incluidos em categorias já propostas por Seilacher em 1953. Desta forma, os icnitos de cultivo e armadilha e os de predação podem ser agrupados junto aos icnitos de alimentação; os icnitos de escape e parte dos de morte junto aos icnitos de locomoção; parte dos de morte dentro dos icnitos de descanso; e os de equilibrio dentro dos icnitos de locomoção ou de habitação. Mesmo havendo estas diferenças de opinião, não há como negar a utilidade que a classificação etológica tem como ferramenta de trabalho tanto para o geólogo quanto para o paleontólogo

\subsubsection{A Proposta de Classificação de Vialov}

A proposta de Vialov (1972) é baseada na diversidade dos icnofósseis (Vestigia vitae). Esta classificação é composta de dois principais grupos, Vivichnia (icnitos produzidos pelo corpo do organismo) e Vivisignia (icnitos dos sinais de funções fisiológicas dos organismos). Os icnitos são também divididos em icnofósseis de invertebrados (Invertebratichnia) e de vertebrados (Vertebratichnia e Vertebratisignia). Os icnitos de invertebrados são classificados como Vivichnia devido à dificuldade de separar a atividade fisiológica do organismo com os vestígios não físiológicos produzidos pelo corpo do organismo.

Esta classificação é baseada na classificação filogenética, utilizando-se inclusive de termos como Ordem e Sub-Ordem. É bastante abrangente com um grande número de subdivisões. Mas, apesar do seu potencial de utilização na criação de uma organização coerente e compreensiva dos icnofósseis, esta classificação não tem sido utilizada pelos icnólogos devido a sua grande especificidade e complexidade. 


\section{Os Icnofósseis e a transição Pré-Cambriano/Cambriano}

A proposta do presente trabalho é de reavaliar os objetos descritos por Zaine (1991) como possiveis icnofósseis e dubiofósseis do Grupo Alto Paraguai, de idade ainda imprecisa mas consensualmente colocada próximo ao limite Proterozóico/Cambriano. Justifica-se, portanto, uma breve exposição sobre os fósseis que marcam esta transição, mais especificamente os icnofósseis.

A transição Pré-Cambriano/Cambriano é um importante marco na história evolutiva da vida. O registro fossilífero do Pré-Cambriano é, em sua maioria, microscópico (Schopf, 1992). As ocorrências de registros macroscópicos estão restritas a quatro principais grupos de fósseis: estromatólitos - estruturas biossedimentares, que se formam através da interação de comunidades de microorganismos (principalmente cianobactérias) com processos sedimentológicos, normalmente em ambientes de deposição carbonática (Srivastava, 2000); elementos da "fauna de Ediacara" - moldes corpóreos de metazoários primitivos desprovidos de qualquer carapaça ou elemento esqueletal biomineralizado (Runnegar, 1992); raros tubos finos calcificados (por exemplo, Cloudina -ver Zaine, 1991, e Grant, 1990) - os precursores da explosão cambriana de "small shelly fossils (SSF)" (Bengtson, 1994); e icnofósseis (Crimes, 1994). A abundância destes fósseis é variada. Por exemplo, enquanto o registro de estromatólitos ao longo do Proterozóico é abundante, próximo ao limite Pré-Cambriano/Cambriano ocorre um declínio em sua abundância, talvez por terem sido fonte de alimento para os metazoários primitivos surgidos nesta época (Walter \& Heyes, 1985). Os organismos do tipo de "fauna de Ediacara", embora tenham ampla distribuição geográfica em rochas siliciclásticas, exibem restrita amplitude temporal no final do Proterozóico, mas a maioria não sobreviveu até o Cambriano, provavelmente em função da expansão de organismos mais complexos. Os calcários fósseis tubulares têm distribuição temporal semelhante à da fauna de Ediacara mas estão restritos a rochas carbonáticas. Os icnofósseis surgem no registro pré-cambriano na mesma época da fauna de Ediacara e dos tubos calcários e se estendem através da transição, chegando até os dias atuais. São amplamente distribuídos geograficamente e ocorrem in situ, preferencialmente em rochas siliciclásticas. 
Os principais fatores que tornam importante o estudo dos icnofósseis na transição PréCambriano/Cambriano são: a) Por evidenciar a presença dos primeiros metazoários macroscópicos - assim, são evidências importantes dessa importante etapa evolutiva; b) $O$ seu potencial de preservação em rochas clásticas -- as sequêencias mais bem preservadas desta transição são compostas, em sua maioria, por sedimentos clásticos marinhos de águas rasas, favoráveis para a preservação de icnofósseis; c) O seu potencial correlativo -.. neste período ocorre uma rápida diversificação dos icnofósseis com bom potencial correlativo tanto pela pequena amplitude temporal de algumas formas, como pela primeira ocorrência de formas de amplitude temporal maior.

O grau da diversificação dos icnofósseis deste período é tamanho que Seilacher, já em 1956, comparando os icnitos proterozóicos simples e pouco diversificados, com as formas complexas e de grande diversidade do Cambriano, sugeriu um processo de "explosão evolutiva". Esta explosão representa o reflexo da evolução dos organismos, de seu comportamento e de sua capacidade de gerar icnitos. Ainda que diversos novos icnofósseis pré-cambrianos tenham sido descritos, desde então, eles só vêm a confirmar o grande aumento da abundância, diversidade e complexidade dos icnofósseis próximos ao limite Pré-Cambriano/Cambriano (e.g. Alpert, 1977; Brasier, 1982; Crimes, 1987, 1989 e 1992). A ocorrência de icnofósseis em sucessão da transição Pré-Cambriano/Cambriano já foi descrita nos Estados Unidos, Canadá, Groelândia, Suécia, Noruega, Polônia, Inglaterra, Ucrânia, Rússia, Espanha, China, Índia, Marrocos, Namíbia, Austrália e Argentina (Crimes, 1989 e 1994).

As subdivisões do Proterozóico e do Cambriano adotadas neste trabalho seguem a nomenclatura russa, que divide a última metade do Proterozóico em Rifeano (inferior, médio e superior) e Vendiano e o Cambriano Inferior em Tommotiano, Atdabaniano e Botomiano (Figura 4.1). A grande discussão em torno desta nomenclatura é relativa a posição do andar Nemakit-Daldyniano (ou Manykaniano), atribuído ao final do Vendiano por alguns e ao início do Cambriano Inferior logo abaixo do Tommotiano por outros. Esta controvérsia tem sido discutida por diversos autores (e.g. Rozanov, 1992; Sokolov, 1995) 
sem se chegar a um consenso. Rowland et al. (1998) discutem este problema, sugerindo que o Nemakit-Daldyniano seja considerado como a base do Cambriano Inferior. No entanto, fazem uma ressalva de que os colaboradores russos do artigo preferem que a definição do limite Vendiano/Cambriano seja no limite Nemakit-Daldyniano/Tommotiano. A discussão sobre o posicionamento destes andares, principalmente baseado na ocorrência de restos orgânicos e SSF, que não ocorrem no Grupo Alto Paraguai, não cabe dentro do contexto proposto do presente trabalho. Assim sendo adotaremos o limite Vendiano/Tommotiano como o limite Proterozóico/Cambriano.

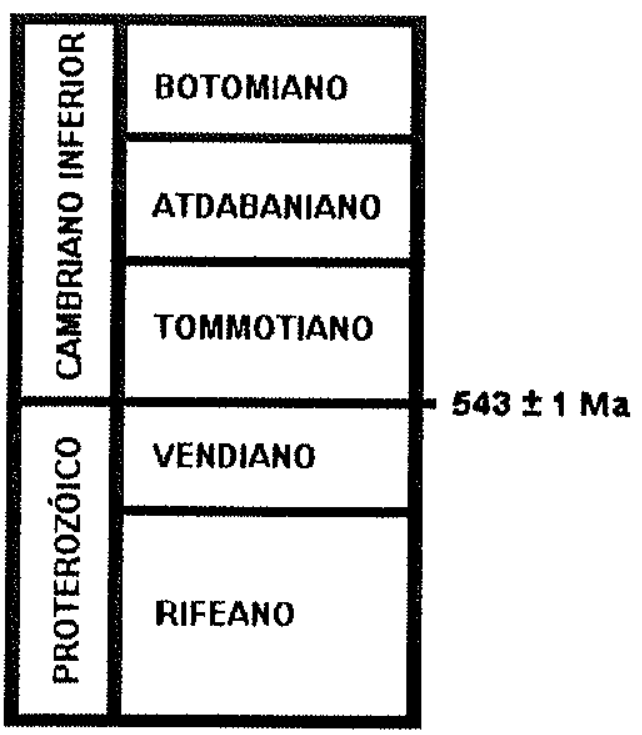

Figura 4.1 - Subdivisões da metade final do Proterozóico e do Cambriano Inferior, de acordo com a nomenclatura russa. O limite Proterozóico/Cambriano é definido em $543 \pm 1 \mathrm{Ma}(\mathrm{Knoll}, 1996)$.

\subsection{O zoneamento icnológico da transição Pré-Cambriano/Cambriano}

O primeiro a tentar caracterizar o registro dos icnofósseis que ocorrem próximos ao limite Pré-Cambriano/Cambriano foi Alpert (1977), que distingui três grupos de icnofósseis. O primeiro grupo compreende os icnofósseis restritos ao final do Pré-Cambriano (e.g. Bunyerichnus, Buchholzbrunnichnus, Archaeichnium, Vimenites, Vendichnus). O segundo grupo inclui os icnofósseis cuja amplitude se estende através do limite e cuja ocorrência não serve para delimitá-lo (e.g. Planolites, Didymaulichnus, Gordia, Skolithos). E o terceiro grupo é composto por icnogêneros que indicam uma idade Cambriano Inferior (e.g. Cruziana, Rusophycus, Teichichnus, Phycodes). 
Da mesma forma que Alpert (1977), Crimes (1987) reconheceu três zonas distintas de icnofósseis, levandorse em conta a aparente restrição de certos icnofósseis a uma das zonas e o primeiro aparecimento de icnofósseis de grande amplitude. Zona I corresponde ao Vendiano superior, com poucos icnogêneros, todos morfologicamente simples e de orientação subhorizontal. Zona II, de idade Tommotiano Inferior, apresenta as primeiras ocorrências de formas complexas. Zona III engloba o Tommotiano Superior e o Atdabaniano Inferior, onde aparecem icnofósseis de artrópodes e formas com Spreiten. (Tabela 4.1) Os principais icnofósseis presentes nestas zonas estão representados, esquematicamente, nas figuras 4.2 e 4.3 .

\begin{tabular}{|c|c|c|c|}
\hline & & $\begin{array}{l}\text { Icnofósseis provavelmente } \\
\text { restritos a esta Zona }\end{array}$ & $\begin{array}{l}\text { Icnofósseis com primeiro } \\
\text { aparecimento na Zona }\end{array}$ \\
\hline Zona III & $\begin{array}{l}\text { (Tommotiano Superior- } \\
\text { Atdabaniano Inferior) }\end{array}$ & $\begin{array}{l}\text { Astropolichnus, Plagiogmus, } \\
\text { Taphrelminhtopsis circulares. }\end{array}$ & $\begin{array}{r}\text { Dimorphichnus, Rusophycus } \\
\text { Cruziana, Diplichnites. }\end{array}$ \\
\hline Zona II & (Tommotiano Inferior) & & $\begin{array}{r}\text { Diplocraterion, Phycodes, } \\
\text { Teichichnus, Treptichnus }\end{array}$ \\
\hline Zona I & (Vendiano Superior) & $\begin{array}{r}\text { Bilinichnus, Harlaniella, } \\
\text { Nenoxites, Vendichnus, } \\
\text { Palaeopascichnus, Intrites, } \\
\text { Vimerites. }\end{array}$ & $\begin{array}{r}\text { Arenicolites, Cochlicnus, } \\
\text { Dydimaulichnus, Gordia, } \\
\text { Neonereites, Planolites, } \\
\text { Scolicia }\end{array}$ \\
\hline
\end{tabular}

Tabela 4.1 - As três zonas de Crimes (1987) e suas respectivas associações de Icnogêneros. (Modificada de Crimes, 1989). 


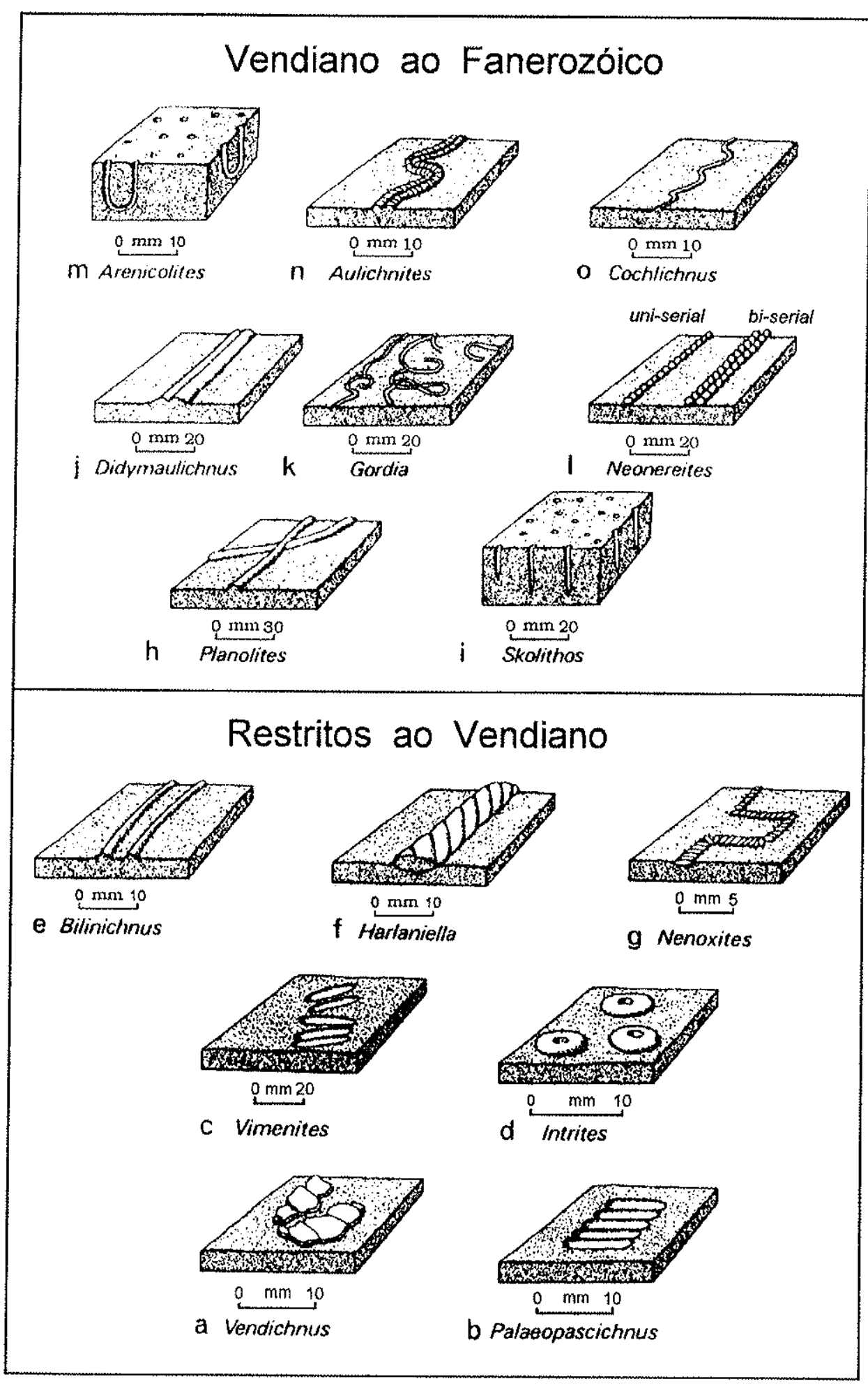

Figura 4.2 - Icnofósseis do Vendiano. Na parte superior, os que ocorrem também no Fanerozóico. Na parte inferior, aqueles que ocorrem somente no Vendiano. (Modificada de Crimes, 1994) 


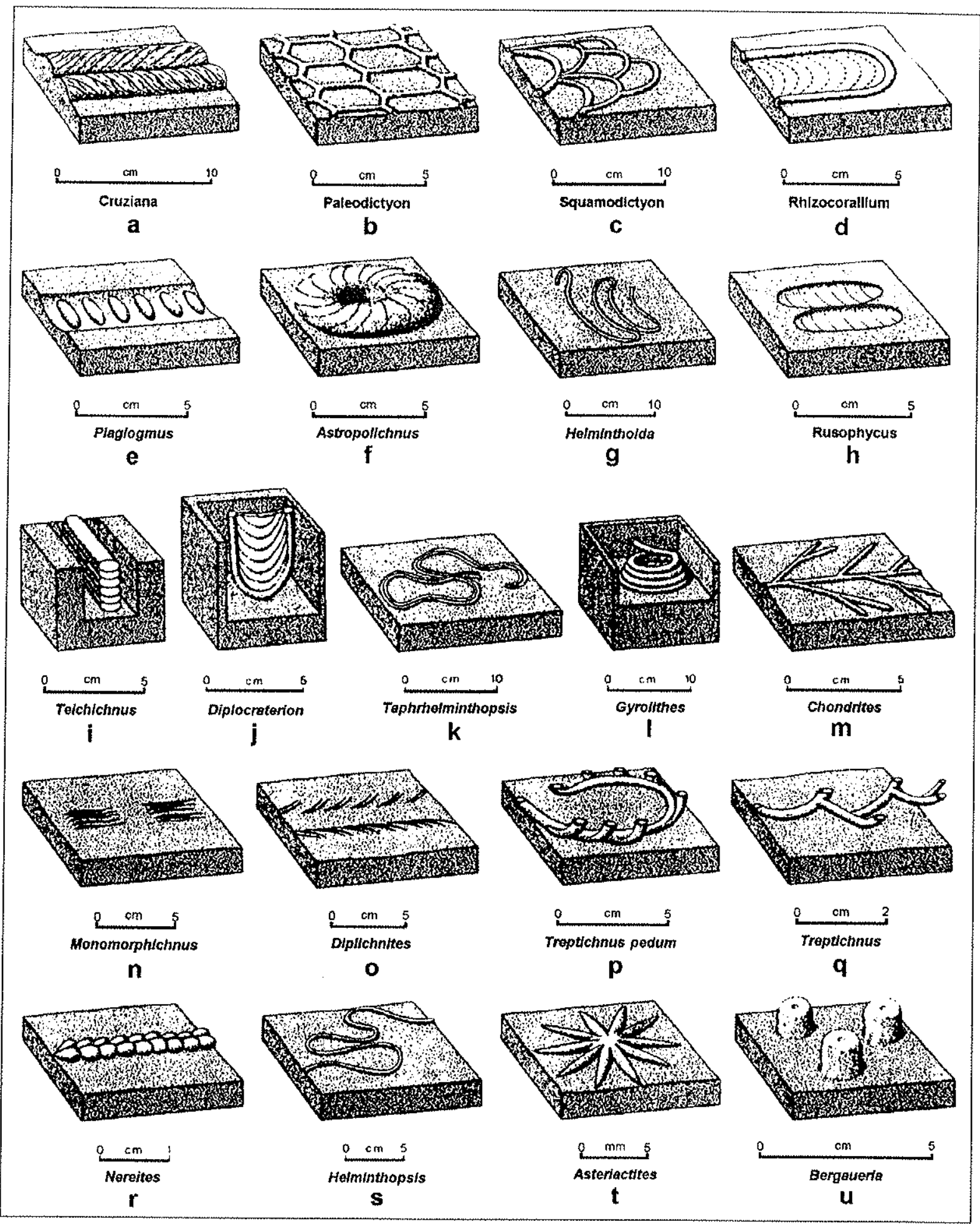

Figura 4.3 - Representação gráfica de alguns importantes icnofósseis Fanerozóicos com registro no Cambriano (Modificada de Crimes, 1994). 
Narbonne \& Myrow (1987), estudando as formações Chapel Island e Random no extremo leste do Canadá (Newfoundland), também subdividiram o intervalo PréCambriano/Cambriano, com base na bioestratigrafia dos icnofósseis. Esta divisão, assim como as de Alpert (1977) e Crimes (1987), inclui três zonas, ou seja, as de Harlaniella podolica, Phycodes pedum e Rusophycus avalonensis. [Uma observação taxonômica se faz necessária aqui: devido à atribuição de Phycodes pedum ao gênero Treptichnus (Jensen \& Grant, 1993; Jensen, 1997; Jensen \& Grant, 1998), a zona do P. pedum é denominada atualmente como zona do Treptichnus pedum.]

A zona da Harlaniella podolica é caracterizada por uma assembléia de icnitos simples, subhorizontais, equivalente à Zona I de Crimes (1987) e identificada em diversas seqüências desta idade. A presença de Harlaniella podolica (Figura 4.2 f) é restrita a esta biozona. A distribuição geográfica desta zona está representada na Fig. 4.4A.

A zona do Treptichnus pedum apresenta maior diversidade e complexidade. As icnoespécies presentes não estão restritas a esta zona. Seu reconhecimento é realizado pela primeira ocorrência de Treptichnus pedum (Figura 4.3 p), e seu topo é a base da zona do Rusophycus avalonensis. É equivalente à Zona II de Crimes (op. cit.). Sua distribuição geográfica está representada na Fig. 4.4B.

A zona do Rusophycus avalonensis, equivalente à Zona III de Crimes (1987), é definida, em sua base, pelo primeiro aparecimento de Rusophycus avalonensis (Figura $4.3 \mathrm{~h}$ ), Taphrhelminthopsis circularis (Figura $4.3 \mathrm{k}$ ), e vários outros icnofósseis, como pode ser visto na Fig. 4.5. Ela termina com a primeira ocorrência de trilobitas. As formas nesta zona são mais complexas e diversificadas que na zona anterior. Estas formas geralmente adentram a zona dos trilobitas, mas Rusophycus avalonensis e Taphrhelminthopsis circularis parecem ser restritos a ela. A ocorrência geográfica desta zona pode ser observada na Fig. 4.4C. 


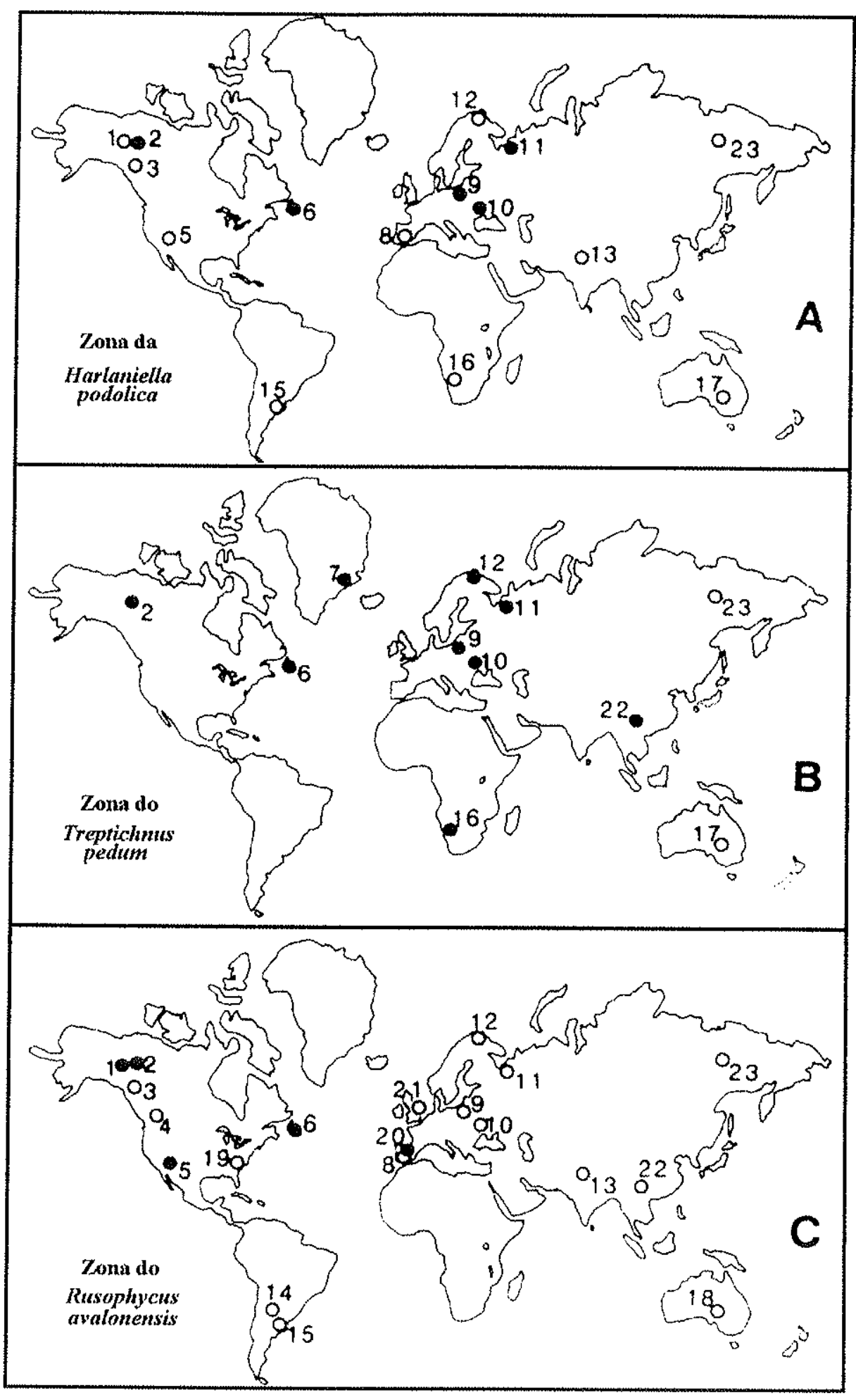

Figura 4.4 - Distribuição das biozonas Harlaniella podolica(A), Treptichnus pedum(B) e Rusophycus avalonensis(C). Os pontos pretos indicam a presença das espécies típicas destas zonas e os pontos brancos indicam a presença de outras espécies ou assembléias destas zonas. (Modificado de Narbonne \& Myrow, 1987). 


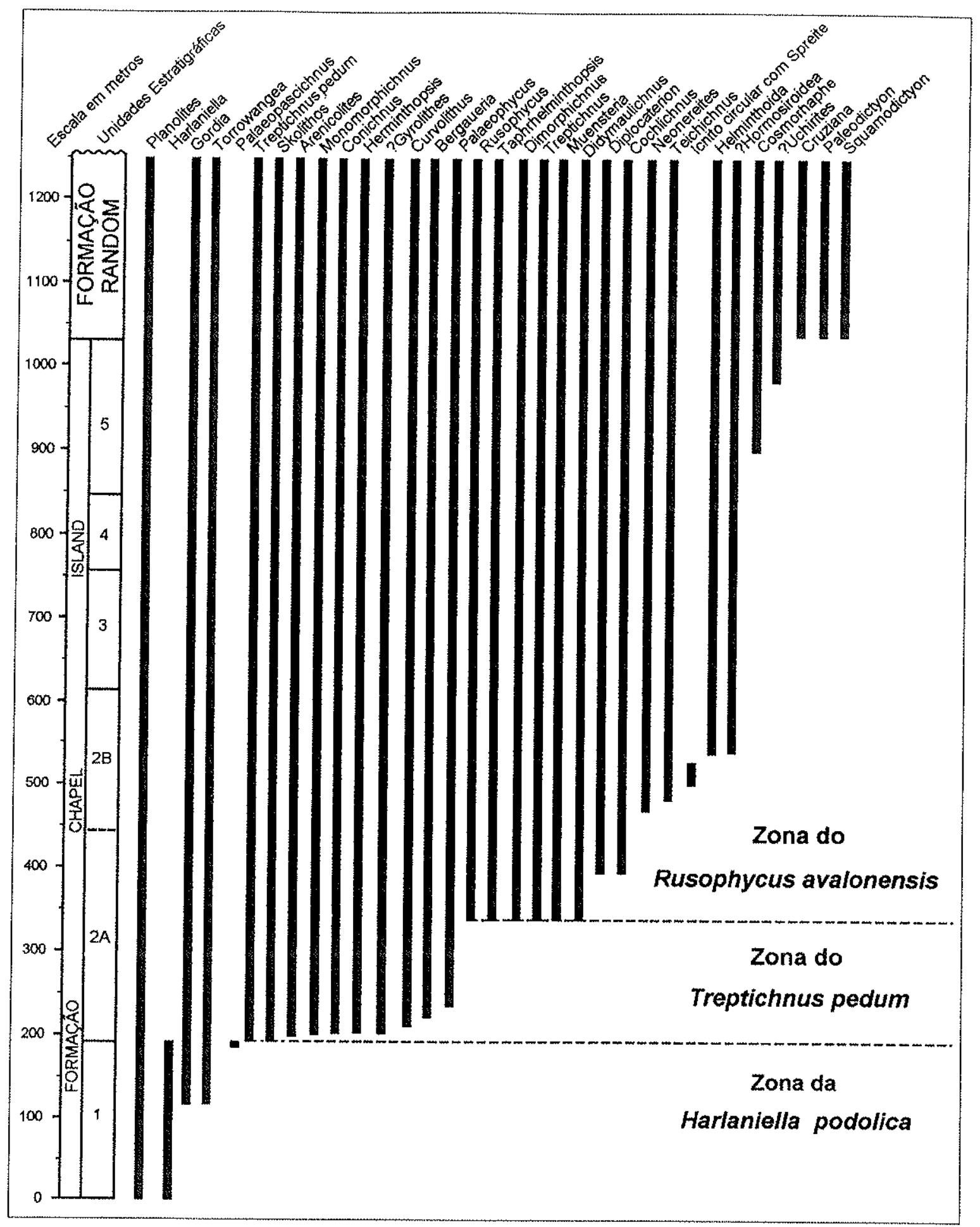

Figura 4.5 -... Divisão do intervalo Pré-Cambriano/Cambriano de Narbonne \& Myrow (1987) para as formações Chapel Island e Random, baseada na bioestratigrafia dos icnofósseis. 
MacNaughton \& Narbonne (1999), diferenciaram, na parte superior da zona de Rusophycus avalonensis, uma nova zona, denominada a zona de Cruziana tenella, identificada nas formações Ingta, Backbone Range e Vampire, no noroeste do Canadá. Esta zona é caracterizada, em sua base, pela primeira ocorrência dos icnofósseis em formas de sulcos Cruziana stromnesi e Cruziana tenella, atribuidos à ação de trilobitas e da icnoespécie Plagiogmus arcuatus. Seu topo permanece demarcado pelo primeiro aparecimento de restos esqueletais de trilobitas.

Mais recentemente, Crimes (1994), expandiu este esquema, definindo seis biozonas desde o Rifeano até o Cambriano Inferior: a) Rifeano - com estromatólitos como fósseis megascópicos característicos e poucos icnofósseis duvidosos; b) Varangeriano - também com estromatólitos, correspondendo à glaciação Varanger, com icnofósseis escassos; c) Ediacariano - com fósseis de "corpo mole" e diversos icnofósseis, incluindo alguns sem registro no Cambriano; d) Pós-Ediacariano, Pré-Cambriano - incluindo o aparecimento de "small shelly fossils" e um número um pouco maior de icnofósseis; e) Cambriano InferiorPré Trilobita - com um número abundante e diversificado de icnofósseis fanerozóicos; f) Cambriano Inferior com Trilobitas - incluindo os primeiros trilobitas e icnofósseis mais tipicos do Fanerozóico. Os principais icnogêneros que ocorrem nestas biozonas estão listados na Tabela 4.2, e a relação entre estas biozonas, a diversidade dos icnofósseis e a de fósseis corpóreos pode ser vista nas Figs. 4.6 e 4.7. 
Tabela 4.2 - Distribuição dos icnogêneros nas diferentes biozonas de Crimes (1994). RRifeano; V-Varangeriano; Ed-Ediacariano; PEPC- Pós-Ediacariano, Pré-Cambriano; PTCCambriano Inferior Pré Trilobita; CI- Cambriano Inferior.. (Modificada de Crimes, 1994).

\begin{tabular}{|c|c|c|c|c|c|c|}
\hline & $\mathrm{R}$ & V & Fi & 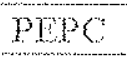 & $\mathrm{PTC}$ & CI \\
\hline Begarem & $?$ & $?$ & $x$ & $x$ & $x$ & $x$ \\
\hline Whoties & $x$ & $x$ & $x$ & $\mathrm{x}$ & $x$ & $x$ \\
\hline Belonelpomes & & $x$ & $x$ & & & \\
\hline ofholmes & & $x$ & $x$ & $\mathrm{x}$ & $\mathrm{x}$ & $x$ \\
\hline Mnbia & & $x$ & $x$ & & & \\
\hline Aremphts & & & $x$ & $\mathrm{x}$ & $x$ & $x$ \\
\hline Binnme & & & $x$ & $\mathrm{x}$ & $x$ & $\mathrm{x}$ \\
\hline Wrokelt & & & $x$ & $x$ & $x$ & $x$ \\
\hline Buonolummones & & & $x$ & $\mathrm{x}$ & $x$ & $x$ \\
\hline orophomes & & & $x$ & & & \\
\hline anolimes & & & $x$ & $\mathrm{x}$ & $x$ & $x$ \\
\hline Grtir & & & $x$ & $x$ & $\mathrm{x}$ & $\mathrm{x}$ \\
\hline onolites & & & $x$ & $x$ & $x$ & $x$ \\
\hline Wemintoids & & & $x$ & $x$ & $x$ & $x$ \\
\hline Wenmintmonnes & & & $x$ & $x$ & $\mathrm{~s}$ & $x$ \\
\hline Fenminopers & & & $x$ & $x$ & $x$ & $x$ \\
\hline Homosirame & & & $x$ & $x$ & $\mathrm{x}$ & $x$ \\
\hline mines & & & $x$ & & & \\
\hline Eलment & & & $x$ & $\mathrm{x}$ & $\mathrm{x}$ & $x$ \\
\hline Wumentonts & & & $x$ & & & \\
\hline Hommonphome & & & $x$ & $\mathrm{x}$ & $x$ & $\mathrm{x}$ \\
\hline Monorites & & & $x$ & & & \\
\hline Mereiter & & & $\mathrm{x}$ & $x$ & $x$ & $x$ \\
\hline Neoneneites & & & $x$ & $x$ & $\mathrm{x}$ & $x$ \\
\hline Paldepasomin & & & $x$ & $x$ & & \\
\hline Potrephyoss & & & $\mathrm{x}$ & $x$ & $x$ & $x$ \\
\hline Selloulichnse & & & $\mathrm{x}$ & $\mathrm{x}$ & $x$ & \\
\hline skothos & & & $x$ & $x$ & $\mathrm{x}$ & $\mathrm{x}$ \\
\hline Sheloghphs & & & $x$ & $x$ & $\mathrm{x}$ & $x$ \\
\hline Selumites & & & $\mathrm{x}$ & & & \\
\hline symponamh & & & $x$ & $\mathrm{x}$ & $x$ & $x$ \\
\hline Torowanges & & & $x$ & $\mathrm{x}$ & $\mathrm{x}$ & $\mathrm{x}$ \\
\hline Mankmas & & & $x$ & & & \\
\hline Mranes & & & $x$ & & & \\
\hline Wowhms & & & $x$ & & & \\
\hline Buhoreph & & & & $\mathrm{x}$ & $x$ & $\mathrm{x}$ \\
\hline Whomethons & & & & $x$ & $x$ & $\mathrm{x}$ \\
\hline montinis & & & & $\mathrm{x}$ & $x$ & $x$ \\
\hline
\end{tabular}


Tabela 4.2 (cont.) - Distribuição dos icnogêneros nas diferentes biozonas de Crimes (1994). R-Rifeano; V-Varangeriano; Ed-Ediacariano; PEPC- Pós-Ediacariano, PréCambriano; PTC-- Cambriano Inferior Pré-Trilobita; CI- Cambriano Inferior.. (Modificada de Crimes, 1994).

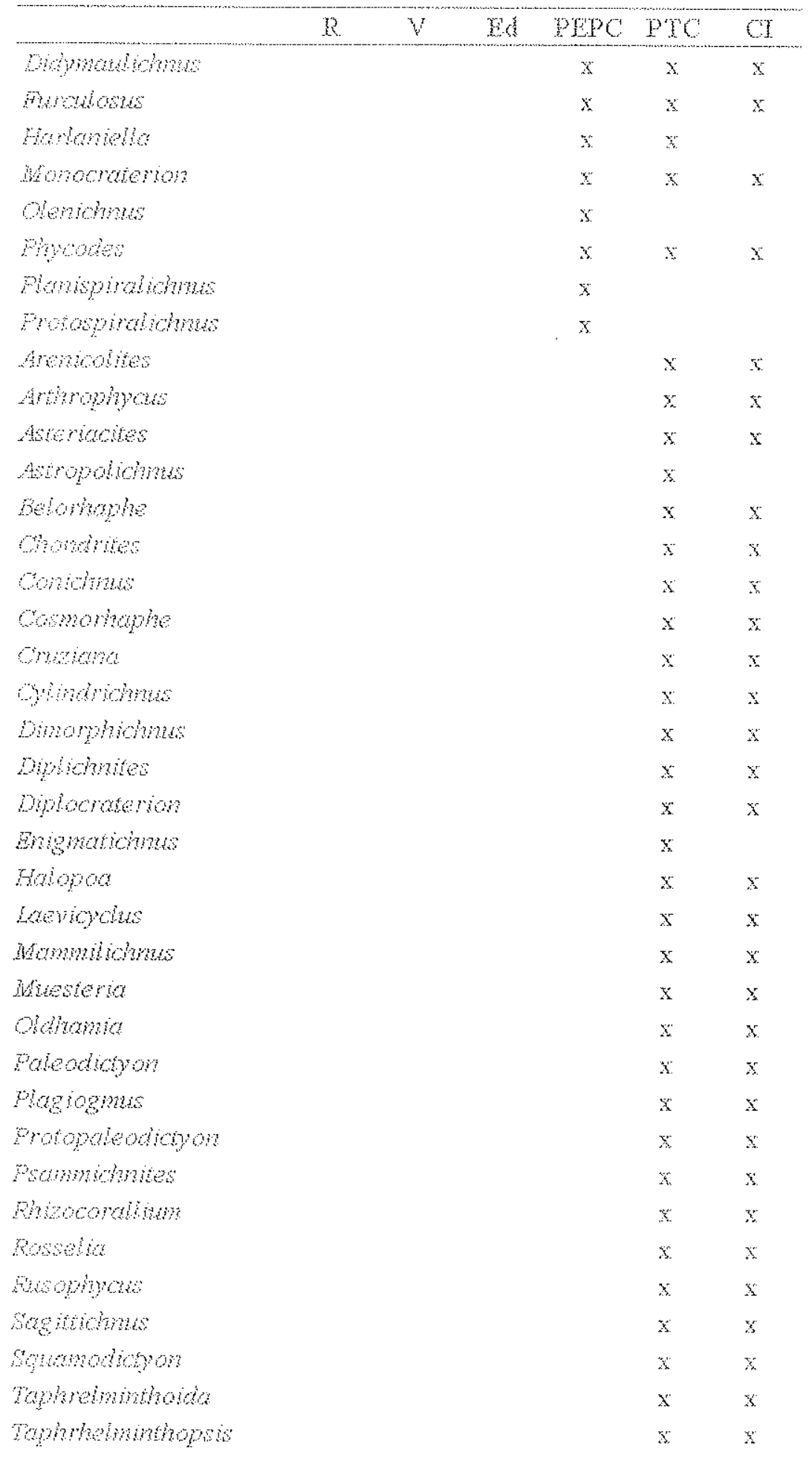


Tabela 4.2 (cont.) -- Distribuição dos icnogêneros nas diferentes biozonas de Crimes (1994). R-Rifeano; V-Varangeriano; Ed-Ediacariano; PEPC- Pós-Ediacariano, PréCambriano; PTC- Cambriano Inferior Pré-Trilobita; Cl- Cambriano Inferior.. (Modificada de Crimes, 1994).

\begin{tabular}{|c|c|c|c|c|c|c|}
\hline & s & V & Ed & PIPC & PTC & Cr \\
\hline Tenonsm & & & & & $x$ & $x$ \\
\hline TPptomites & & & & & $x$ & $x$ \\
\hline Aroracomes & & & & & & $x$ \\
\hline Aroulobus & & & & & & $x$ \\
\hline Crosenchords & & & & & & $x$ \\
\hline mopopola & & & & & & $x$ \\
\hline Dablobltes & & & & & & $\mathrm{x}$ \\
\hline Wobaln & & & & & & $x$ \\
\hline Dolopinmes & & & & & & $x$ \\
\hline Whola & & & & & & $x$ \\
\hline Dusopsis & & & & & & $x$ \\
\hline Gokerichnts & & & & & & $\mathrm{x}$ \\
\hline Gronteria & & & & & & $x$ \\
\hline yrochorte & & & & & & $x$ \\
\hline sopolichns & & & & & & $x$ \\
\hline Laninites & & & & & & $x$ \\
\hline Magorimomos & & & & & & $\mathrm{x}$ \\
\hline Herosomimites & & & & & & $x$ \\
\hline Wutilameld & & & & & & $x$ \\
\hline Protionites & & & & & & $x$ \\
\hline Protomirulata & & & & & & $\mathrm{x}$ \\
\hline Sabelarifex & & & & & & $x$ \\
\hline Scolicia & & & & & & $x$ \\
\hline Taenidiun & & & & & & $\mathrm{x}$ \\
\hline Tasmanadic & & & & & & $x$ \\
\hline Tomaldsh & & & & & & $x$ \\
\hline Eopplopos & & & & & & $x$ \\
\hline
\end{tabular}

Totaldeimogenes $\quad 1 \quad 4 \quad 35 \quad 36 \quad 66 \quad 86$ 


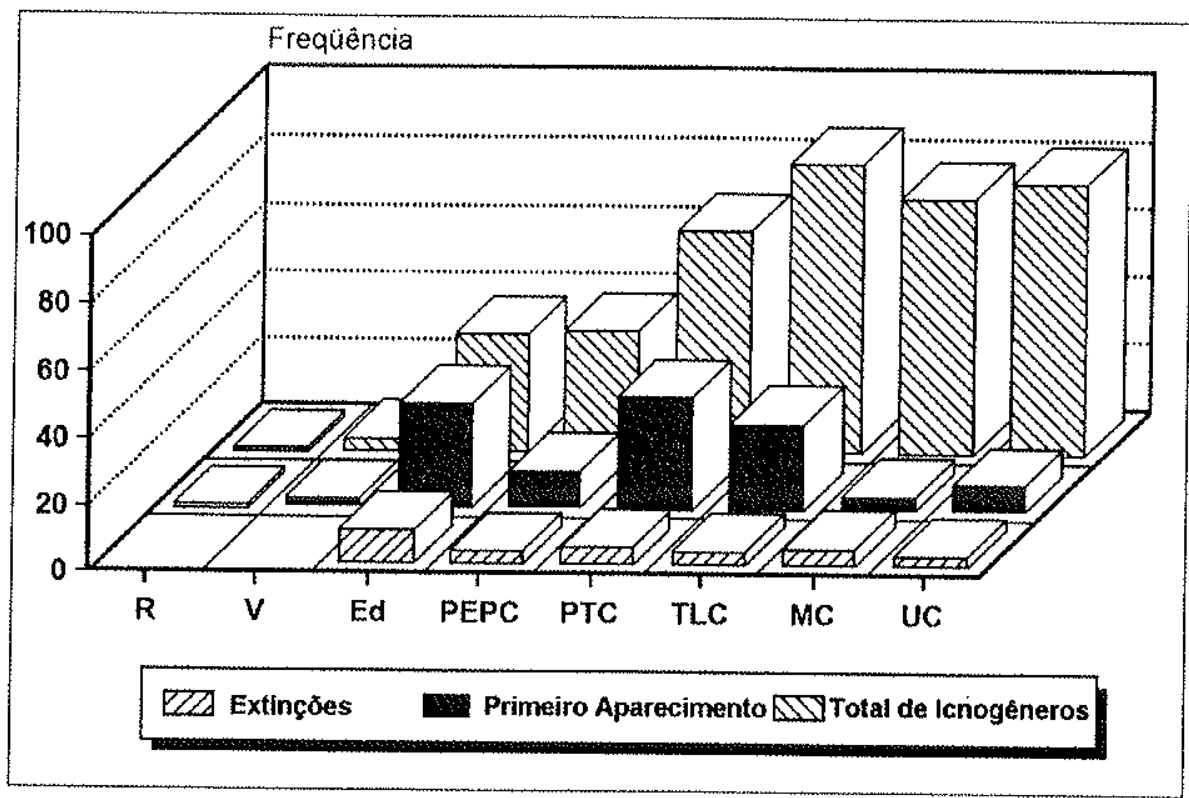

Figura 4.6 - Relação da diversidade de icnogêneros (aparição, extinção e total de icnogêneros) nas biozonas de Crimes (1994) - R-Rifeano; V-Varangeriano; EdEdiacariano; PEPC- Pós-Ediacariano, Pré-Cambriano; PTC- Cambriano Inferior PréTrilobita; TLC-Cambriano Inferior com Trilobitas; MC-Cambriano Médio; UC-Cambriano Superior. (Modificada de Crimes, 1994).

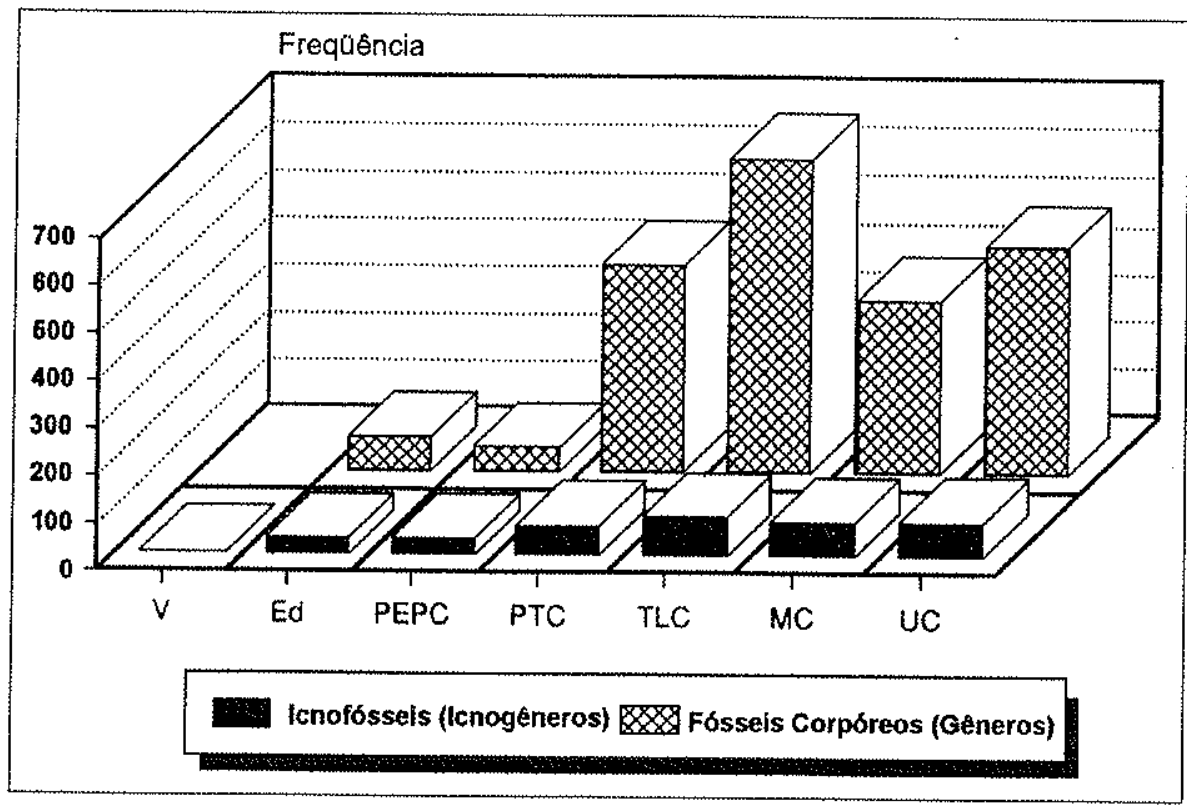

Figura 4.7 - Relação entre a diversidade de icnofósseis e de fósseis corpóreos nas biozonas de Crimes (1994). - V-Varangeriano; Ed-Ediacariano; PEPC- Pós-Ediacariano, PréCambriano; PTC- Cambriano Inferior Pré-Trilobita; TLC- Cambriano Inferior com Trilobitas; MC-Cambriano Médio; UC-Cambriano Superior. (Modificada de Crimes, 1994). 
A partir desta subdivisão Crimes (op. cit.) estabeleceu o seguinte zoneamento icnológico: a) Zona 0 - Ripheano ao Vendiano Inferior (Varangeriano) - apenas com o aparecimento das formas mais simples (i.e. Planolites; ver Killick, 1983); b) Zona IA - Vendiano Superior (Ediacariano) - com o aparecimento de animais do tipo "fauna de Ediacara" e o aumento da diversidade e abundância dos icnofósseis; c) Zona IB - Vendiano Superior (PósEdiacariano, Pré-Cambriano) - com um pequeno aumento da diversidade dos icnofósseis e o surgimento de algumas formas que não sobreviveram ao surgimento dos trilobitas (i.e. Harlaniella, Olenichnus, Planispiralichnus), Esta zona corresponderia à zona de Harlaniella podolica de Narbonne \& Myrow (1987); d) Zona II - Tommotiano Inferior (parte inferior do Cambriano Inferior pré-trilobita) - Aparecem alguns icnofósseis típicos do Fanerozóico, de natureza mais complexa, apresentando formas com estruturas tridimensionais bem desenvolvidas (i.e. Treptichnus, Teichichnus). Esta zona corresponde à zona do Treptichnus pedum de Narbonne \& Myrow (op. cit.); e) Zona III - Tommotiano Superior ao Atdabaniano Inferior - Aparecem vários icnofósseis, incluindo os icnitos de trilobitas (i.e. Cruziana, Diplichnites, Rusophycus) e algumas aparentemente restritas a esta zona (i.e. Astropolichnus, Taphrhelminthopsis circularis). Esta zona corresponde à zona do Rusophycus avalonensis de Narbonne \& Myrow (op.cit.). A Fig. 4.8 compara estes diversos esquemas, relacionando-os, inclusive, com a subdivisão russa e o estratótipo do limite PréCambriano/Cambriano em Newfoundland.

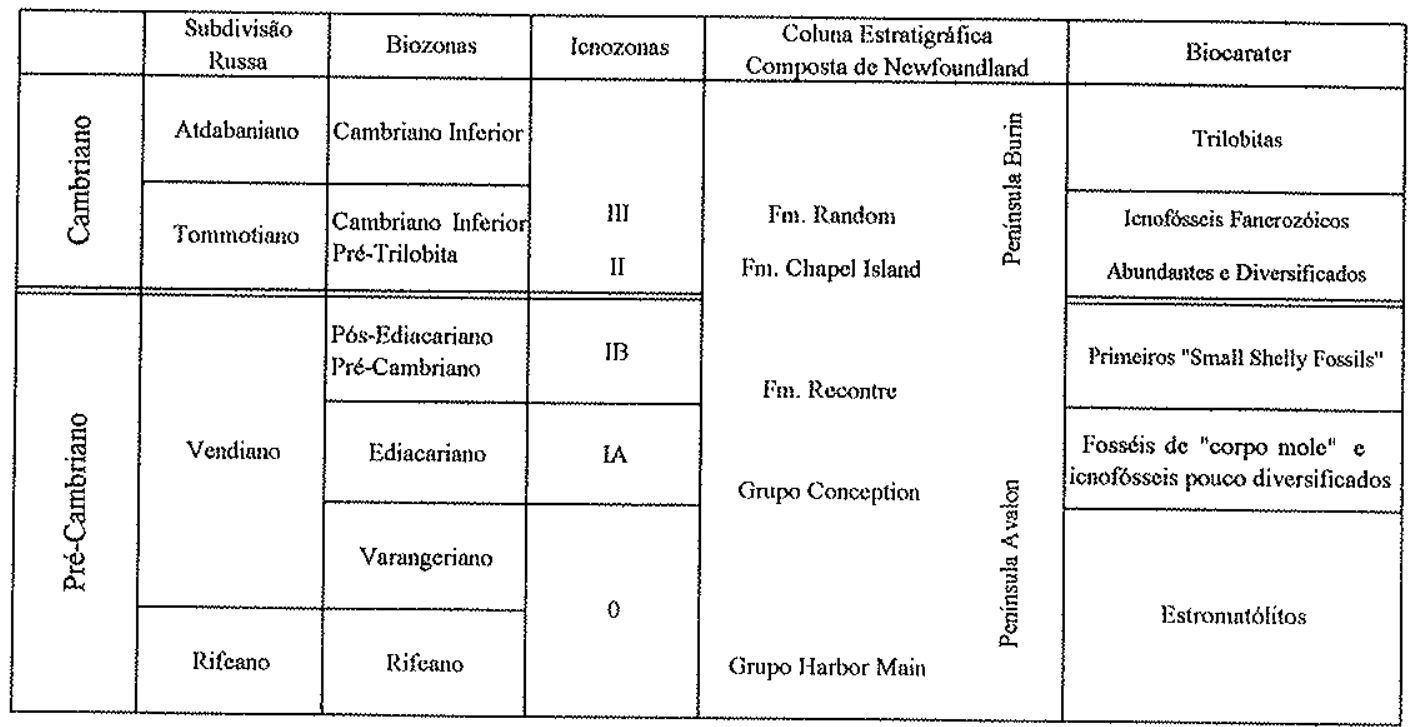

Figura 4.8 - As biozonas e suas relações com as icnozonas e a seqüência estratótipo da transição Pré-Cambriano/Cambriano. (Modificada de Crimes, 1994) 
Desde que Crimes (1994) redefiniu seu esquema, no qual incluiu uma subdivisão e uma biozona que corresponderiam a um suposto período de tempo posterior à extinção da fauna de Ediacara mas anterior à irradiação adaptativa que marcou o começo do Cambriano, novas descobertas no Neoproterozóico terminal da Namíbia e na famosa fauna de Burgess (Cambriano Médio, Canadá) demonstraram que alguns elementos da fauna de Ediacara sobreviveram até o final do Pré-Cambriano, adentrando, possivelmente, até no Cambriano (ver Knoll, 1996; Conway-Morris, 1993; Hagadorn et al., 2000). Estas novas revelações exigem certa cautela quando da utilização do conceito de biozona $\mathrm{IB}$, correspondente à postulada lacuna entre as faunas de Ediacara e do Cambriano.

\subsection{A seqüência estratótipo do limite Pré-Cambriano/Cambriano.}

A distribuição geográfica de seqüências candidatas ao estratótipo do limite PréCambriano/Cambriano é bastante ampla (Figura 4.9). Entretanto, apenas três chegaram à fase final da escolha deste estratótipo: Aldan River na antiga União Soviética, Meishucun na China e Fortune Head - Península Burin, no Canadá. Em 1992 a seqüência de Fortune Bay, Newfoundland, Canadá foi escolhida pelo voto dos membros da Comissão Internacional de Estratigrafia da International Union of Geological Sciences (IUGS) como seção e ponto tipos do limite Pré-Cambriano/Cambriano (Precambrian-Cambrian Global Stratotype Section and Point, ou seja, GSSP) (Cowie, 1992). 


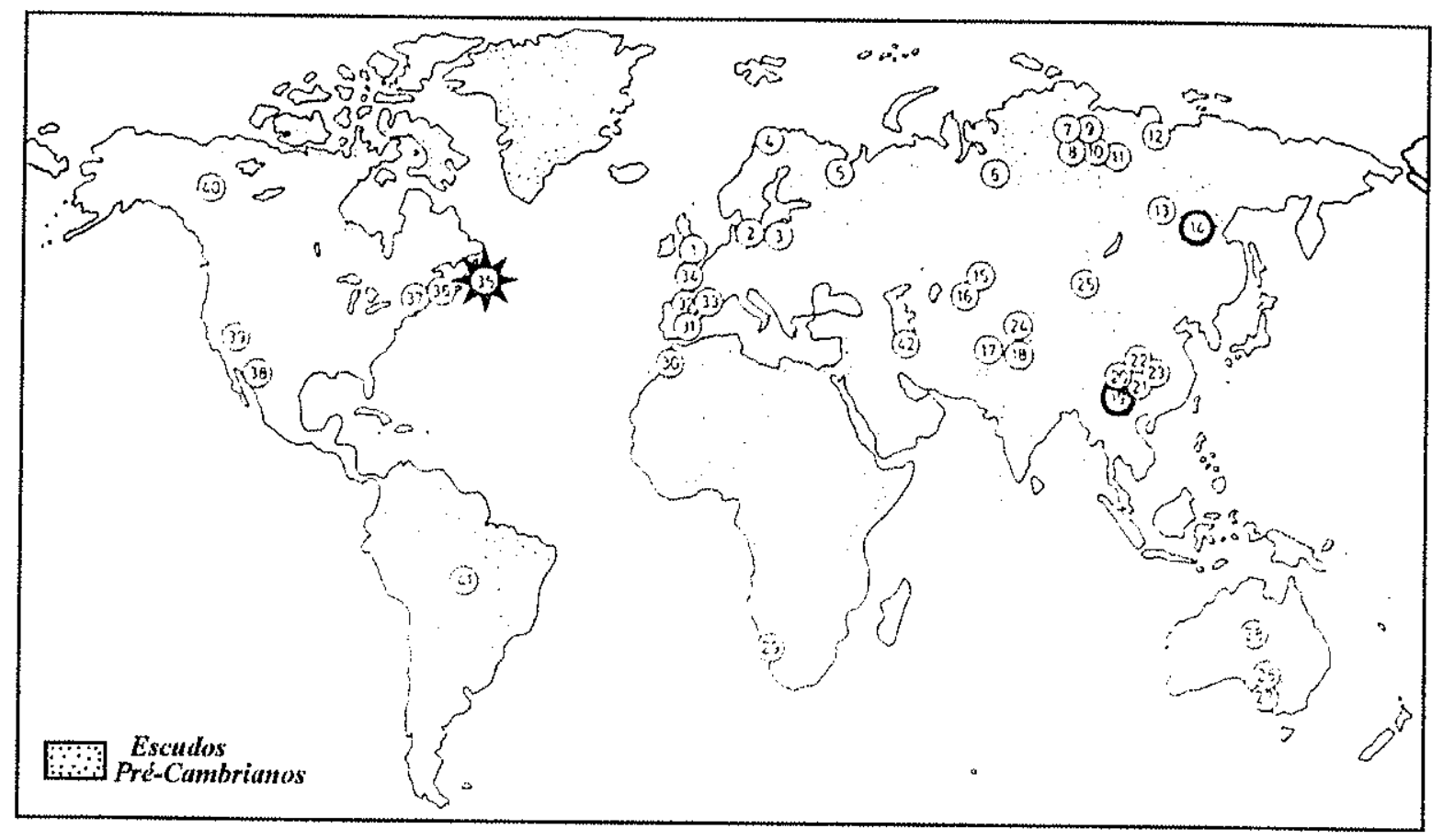

Figura 4.9 - Algumas localidades de importantes seções do limite Pré-Cambriano/ Cambriano (círculos numerados). As seqüências candidatas a estratótipo do limite Pré-Cambriano/Cambriano estão representadas pelos pontos em destaque, 14 (Aldan River, Antiga URSS), 19 (Meishucun, China) e 35 (Península de Fortune Head - Península Burin, Canadá). O ponto 41 corresponde ao Grupo CorumbáMS. (Modificado de Cowie, 1992)

A seqüência estratótipo de Fortune Head na Península Burin exibe uma sucessão espessa de estratos marinhos, fossiliferos, essencialmente contínua. É composta, da base para o topo, das formações Rencontre, Chapel Island e Random. O seu conteúdo fossillfero inclui icnofósseis, "small shelly fossils", algas vendotaenídeas, organismos do tipo "fauna de Ediacara" e microfósseis. O limite Pré-Cambriano/Cambriano foi escolhido por Narbonne et al. (1987) na Formação Chapel Island, a 2,4 metros da base do membro 2, ou seja, aproximadamente a $190 \mathrm{~m}$ da base desta formação. Esta definição baseou-se na primeira ocorrência do icnofóssil Treptichnus pedum, reforçada pelas primeiras ocorrências de "small shelly fossils" a partir deste ponto. 


\subsection{Diversificação dos icnofósseis na transição Pré-Cambriano/Cambriano}

$\mathrm{O}$ aumento da diversidade dos icnofósseis na transição Pré-Cambriano/Cambriano foi inicialmente sugerida por Seilacher (1956). Posteriormente, Crimes (1974) resumiu o que se sabia da diversidade dos icnofósseis e de sua disposição batimétrica do Pré-Cambriano ao Terciário (Figura 4.10). Crimes voltou a abordar este tema em 1992 e 1994, enfocando a evolução morfológica dos icnofósseis na transição Pré-Cambriano/Cambriano. Este aumento da diversidade de formas está diretamente ligado à evolução de estilos de comportamento e hábitos dos metazoários primitivos. Segundo Crimes (1992), esta evolução dos icnofósseis está evidenciada de dois modos: pelo aparecimento de diferentes linhagens de icnofósseis, sucessivamente mais complexos (Figura 4.11) -- por exemplo, os icnitos ramificados surgiram antes dos icnitos com Spreite; e pelo desenvolvimento subseqüente de padrões mais complexos de cada linhagem (Figuras 4.12, 4.13, 4.14. e 4.15) -- por exemplo icnitos simples não ramificados surgiram antes que icnitos irregularmente ramificados. Na opinião de Crimes (op. cit.), nota-se un declínio nos icnitos de atividade mais simples (alimentação) enquanto os icnitos de atividade mais complexa (descanso, pastagem e habitação) aumentam a partir do Tommotiano Superior, especialmente que coincide com a expansão de metazoários biomineralizados mais eficientes (Tabela 4.3).

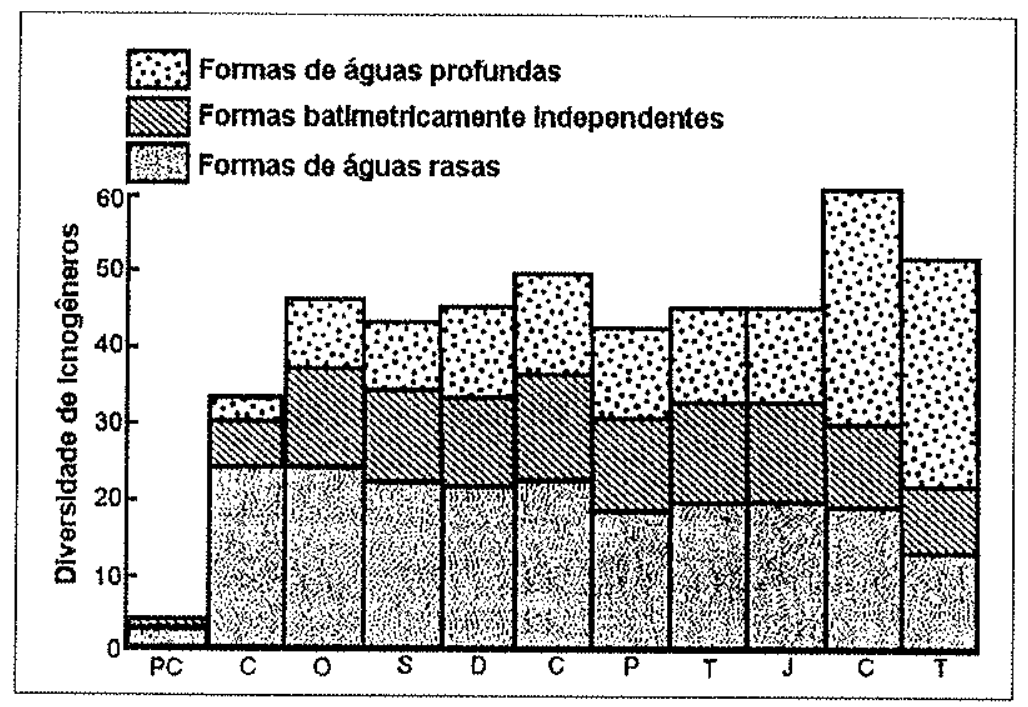

Figura 4.10 - Relação entre a diversidade de icnogêneros e sua disposição batimétrica, do Pré-Cambriano (PC) ao Terciário (T) (Modificada de Crimes, 1974). 


\begin{tabular}{|c|c|c|}
\hline 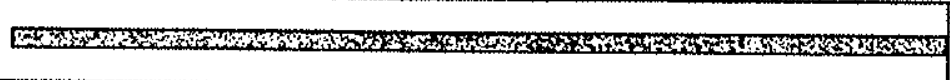 & & $\begin{array}{l}\text { Ienitos } \\
\text { simples }\end{array}$ \\
\hline HSL & & $\begin{array}{l}\text { Ienitos } \\
\text { de pottots }\end{array}$ \\
\hline 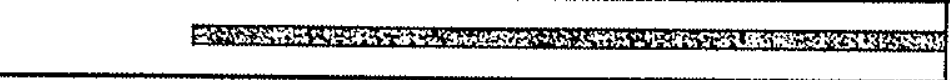 & & $\begin{array}{l}\text { Icnitos } \\
\text { bllobados }\end{array}$ \\
\hline Whar & & $\begin{array}{l}\text { icnitos } \\
\text { verticals }\end{array}$ \\
\hline 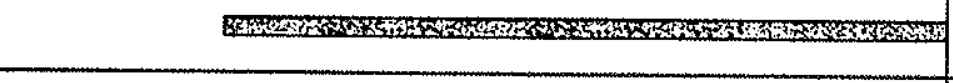 & & $\begin{array}{l}\text { Icnitos de } \\
\text { descanso da } \\
\text { celenterados }\end{array}$ \\
\hline 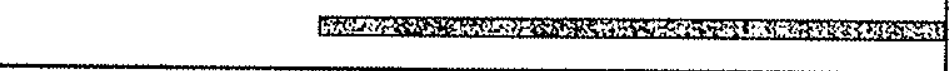 & & $\begin{array}{l}\text { Icnitos do } \\
\text { artropodes }\end{array}$ \\
\hline 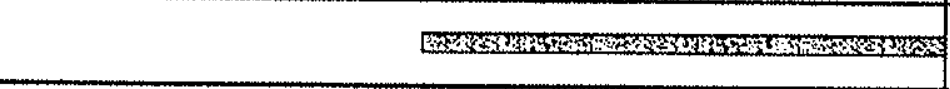 & $e_{0}^{4}$ & $\begin{array}{l}\text { Icnitos } \\
\text { radials }\end{array}$ \\
\hline 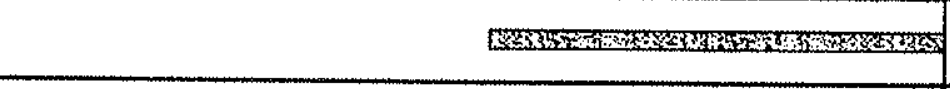 & & $\begin{array}{c}\text { fenitos } \\
\text { com } \\
\text { ramfificaçoes }\end{array}$ \\
\hline 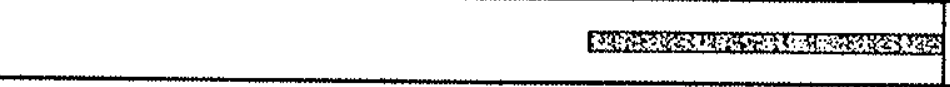 & & $\begin{array}{l}\text { Icnitos } \\
\text { com } \\
\text { sprafte }\end{array}$ \\
\hline VENDIANO & & \\
\hline CAMBRIANOINFERIOR & & \\
\hline
\end{tabular}

Figura 4.11 - Aparecimento de diferentes linhagens de icnofósseis no final do PréCambriano e no inicio do Cambriano, com o aumento de sua complexidade morfológica (Modificada de Crimes, 1992).

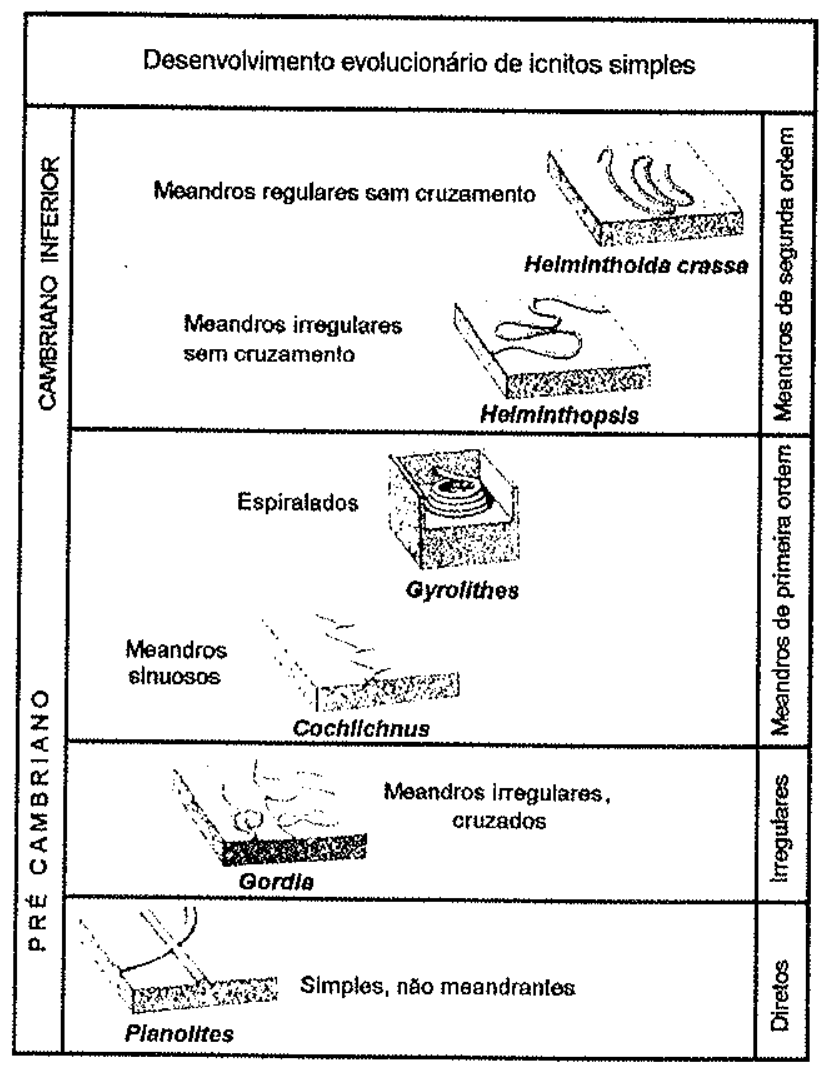

Figura 4.12-Desenvolvimento de icnitos simples na transição Pré-Cambriano/Cambriano (Modificada de Crimes, 1992). 

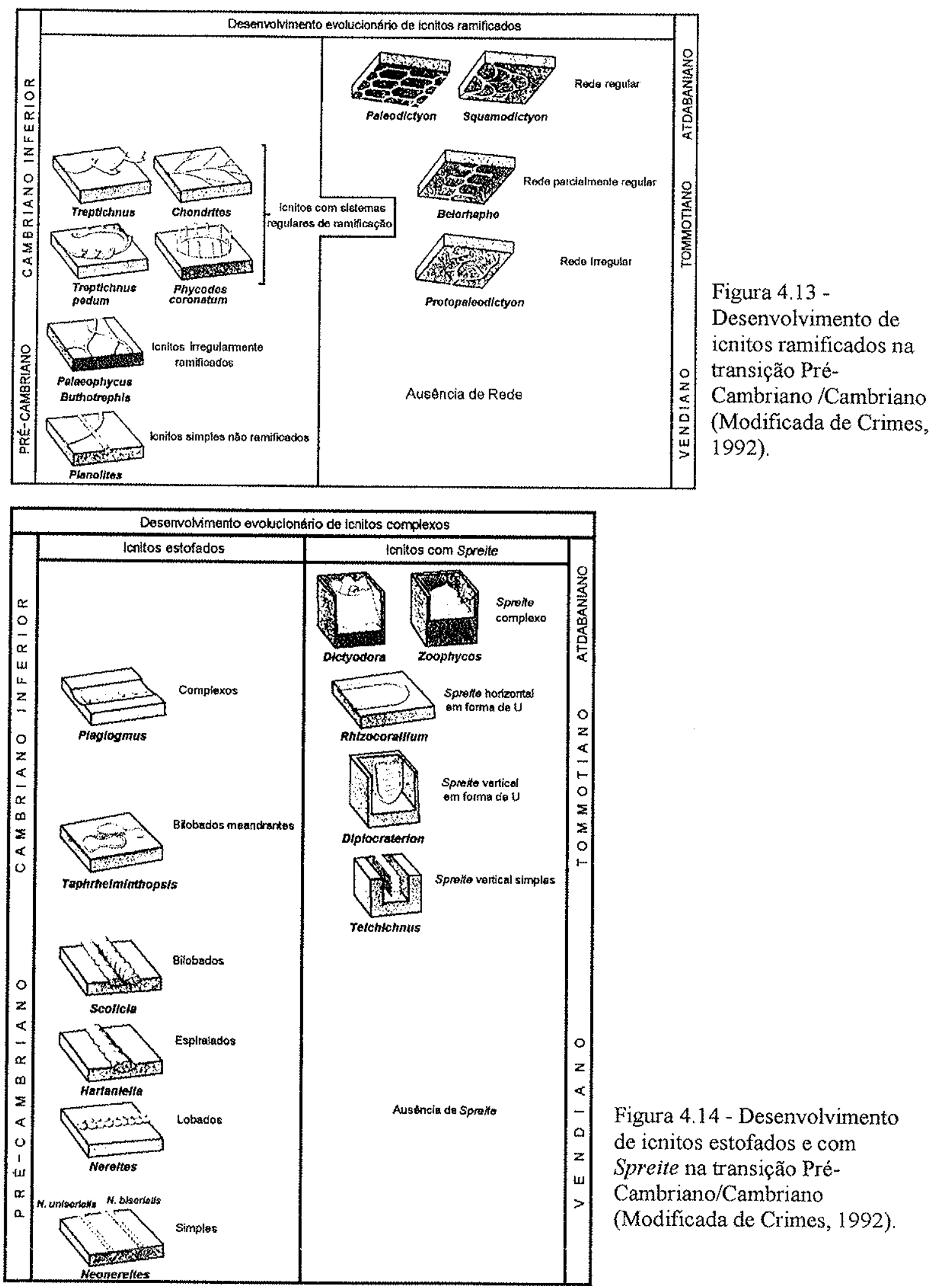

Figura 4.14 - Desenvolvimento de icnitos estofados e com Spreite na transição PréCambriano/Cambriano (Modificada de Crimes, 1992). 


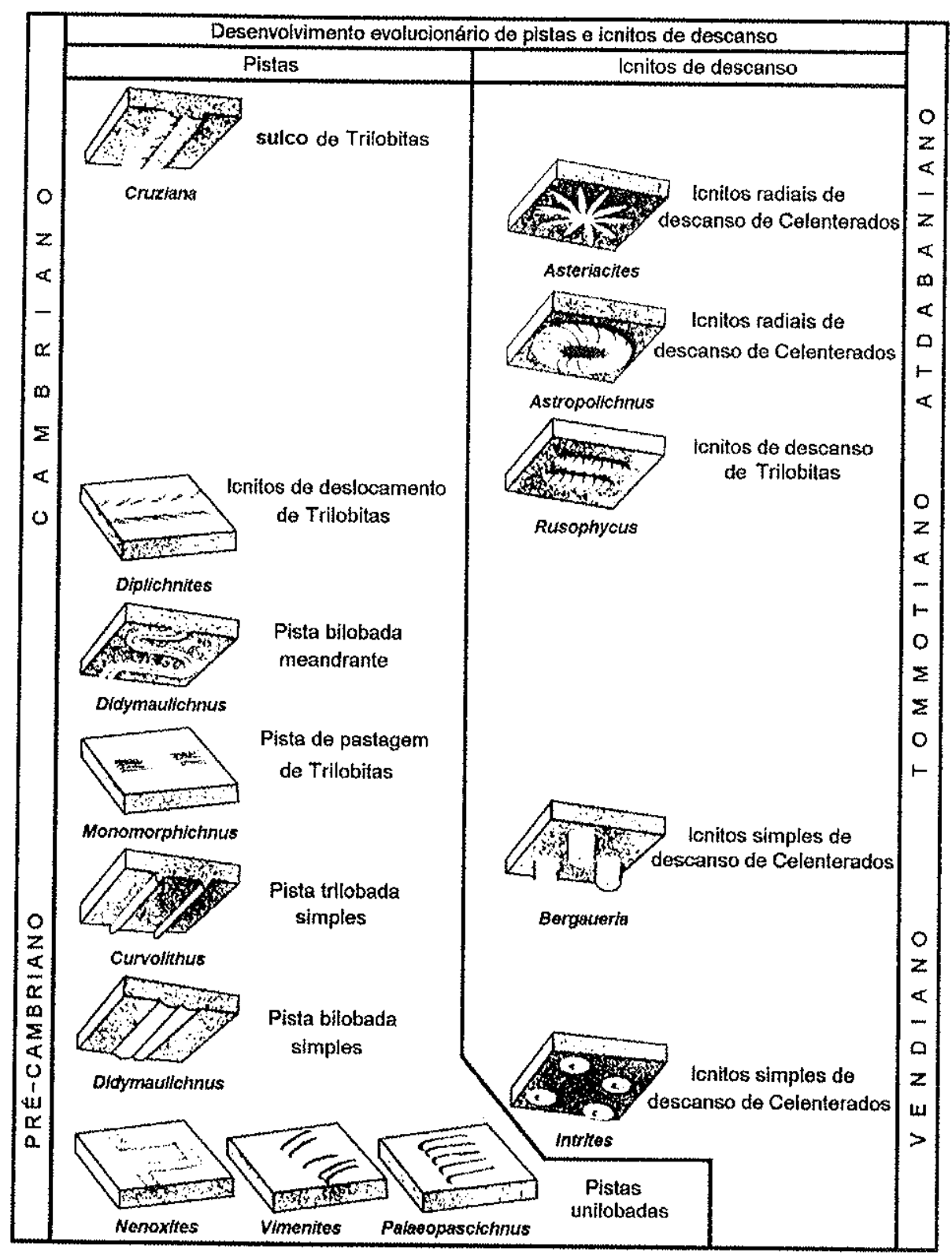

Figura 4.15 - Desenvolvimento de pistas e icnitos de descanso na transição Pré-Cambriano/Cambriano (Modificada de Crimes, 1992). 


\begin{tabular}{lcccc}
\hline $\begin{array}{c}\text { Grupo } \\
\text { Etológico }\end{array}$ & Vendiano & $\begin{array}{c}\text { Tommotiano } \\
\text { Inferior }\end{array}$ & $\begin{array}{c}\text { Tommotiano } \\
\text { Superior }\end{array}$ & Atdabaniano \\
\hline Alimentação & $52 \%$ & $57 \%$ & $47 \%$ & $40 \%$ \\
Habitação & $10 \%$ & $9 \%$ & $11 \%$ & $15 \%$ \\
Descanso & $14 \%$ & $9 \%$ & $14 \%$ & $15 \%$ \\
Deslocamento & $14 \%$ & $17 \%$ & $11 \%$ & $11 \%$ \\
Pastagem & $10 \%$ & $9 \%$ & $17 \%$ & $19 \%$ \\
\hline
\end{tabular}

Tabela 4.3 -- Distribuição etológica dos icnitos da transição Vendiano/Cambriano (Modificada de Crimes, 1992).

\subsection{Icnofósseis do Pré-Cambriano e seus problemas}

$O$ registro de icnofósseis no Pré-Cambriano deve ser analisado cuidadosamente, pois diversos supostos icnofósseis descritos deste período foram posteriormente reinterpretados como de origem inorgânica (e.g. Rhysonetron). Na Paleontologia, quanto mais antigo o objeto estudado, mais cautela se deve ter na sua interpretação. Para Hofmann (1971), os objetos pré-cambrianos supostamente biogênicos devem satisfazer os seguintes quesitos: A estrutura é realmente pré-cambriana e se é, qual a sua idade? $\mathrm{E}$, segundo, a estrutura realmente é de origem biológica e se é, quais as suas afinidades biológicas? O primeiro pode ser resolvido mais facilmente quando existem possibilidades de datação radiométrica da seqüência que encerra o suposto fóssil. O segundo permanece dificil por várias razões, mas principalmente devido à falta de partes duras nos fósseis pré-cambrianos e a tendência dos candidatos a icnitos dessa idade apresentarem morfologias simples (ou até exóticas), comumente muito mais parecidas com diversos tipos de estruturas inorgânicas. Somado a isto, o número de exemplares comumente é muito baixo e a preservação, muitas vezes, precária. 


\begin{abstract}
Atualmente, relatos de ocorrências de icnofósseis de idade superior a $600 \mathrm{Ma}$, ou seja anteriores ao Vendiano e à última glaciação neoproterozóica, são muito contestados. Por exemplo, supostos icnofósseis "vermiformes" de $2.200 \mathrm{Ma}$, Rhysonetron lahtii e Rhysonetron byei, Hofmann (1967), acabaram sendo reinterpretados como gretas de contração (Hofmann, 1971). Outros suspostos icnofósseis de $2.000 \mathrm{Ma}$ foram descritos por Kauffman \& Steidtmann (1981), mas sua origem biogênica não tem sido muito aceita, devido em boa parte à sua idade. Mesmo icnofósseis pré-cambrianos mais novos têm sido reinterpretados como de origem não biogênica, e.g. Vermiforma antiqua $620 \mathrm{Ma}$ (Seilacher et al., 2000), conforme já discutido no capítulo 3. Até o mais renomado dos pesquisadores de icnofósseis, A. Seilacher, tem sentido este problema. Em 1998, Seilacher et al. descreveram icnofósseis de 1.100 Ma na Índia, mas a datação e a biogenicidade destes objetos têm dividido a opinião dos icnólogos (Kerr, 1998). Por estas razões, deve-se ter o máximo de cautela ao lidar com objetos pré-cambrianos de possível origem biogênica, o que pretendemos fazer nesta dissertação em nossa discussão dos supostos icnofósseis e dubiofósseis do Grupo Alto Paraguai descritos por Zaine (1991).
\end{abstract}




\section{Icnofósseis da Formação Cariri, Bacia do Araripe}

\subsection{Introdução}

A Bacia do Araripe (NE do Brasil), onde se localiza a Formação Cariri, é famosa mundialmente pela notável preservação e exuberância fossilifera da Formação Santana, com seus peixes, insetos, répteis, quelônios, anfibios, pterossauros e vegetais cretácicos. Inúmeros trabalhos paleontológicos têm sido realizados nesta região por pesquisadores nacionais e estrangeiros (Beurlen, 1963, 1966, 1971; Price, 1971, 1973 ;Mabesoone \& Tinoco, 1973; Lima, 1978a, 1978b, 1979; Campos \& Kellner, 1985; Silva-Santos \& Valença, 1986; Martill, 1988, 1993; Berthou et al., 1990; Arai \& Coimbra, 1990; Martins Neto, 1990; Maisey, 1991, 1997; Silva Santos, 1991; Kellner et al.; 1999; Sales et al., 1999), no entanto a grande maioria enfoca o seu excepcional conteúdo fossilífero de vertebrados, invertebrados e restos vegetais com pouquíssimos trabalhos sobre icnofósseis (Carvalho et al., 1995; Carvalho, 2000; Albuquerque et. al., 1999, 2000)

A inclusão nesta dissertação do estudo dos icnofósseis da Formação Cariri justifica-se pela série de similaridades entre esta formação e a Formação Raizama (Grupo Alto Paraguai), objeto do estudo paleoicnológico principal da dissertação. Ambas as formações compreendem rochas sedimentares siliciclásticas, que por muito tempo foram consideradas afossiliferas e cuja idade nunca foi determinada com precisão. Ao contrário do Grupo Alto Paraguai, aceita-se para a Formação Cariri uma idade certamente fanerozóica, e este fato torna muito mais real o seu potencial como portadora de restos ou vestígios de animais (ou plantas) pluricelulares. Por isso, ao deparar-se em 1998, com possiveis icnofósseis numa laje de um afloramento clássico desta formação (Albuquerque et. al., 1999, 2000), decidiuse aproveitar a oportunidade de testar e familiarizar-se com a metodologia de pesquisa que seria aplicada na reavaliação dos objetos assinalados por Zaine (1991) como icnofósseis e dubiofósseis provenientes do Grupo Alto Paraguai. 
Também é pertinente mencionar que a coleta desordenada de fósseis nesta região, muitas vezes para serem comercializados ilegalmente, inclusive no Exterior, dificulta as pesquisas geológicas e paleontológicas do Araripe pela perda de informações essenciais sobre a geografia, estratigrafia, tafonomia, paleoecologia e, especialmente, a bioestratigrafia e correlação. Devido à forma da extração deste material, feita em geral por pessoas não qualificadas, e à ausência de valor comercial dos icnofósseis, estes não são explorados e na maioria das vezes nem chegam a ser identificados como fósseis, sendo descartados juntamente com o material afossilifero. Uma coleta ordenada de icnofósseis, levando-se em conta os aspectos estratigráficos, tafonômicos e paleoambientais, acrescentaria valiosas informações sobre a Bacia do Araripe e sua correlação com as outras bacias. Conscientizar o leitor deste potencial é outro objetivo deste capítulo.

\subsection{Contexto Geológico}

A Bacia do Araripe, localizada na Chapada do Araripe no nordeste do Brasil, se estende por aproximadamente $7.200 \mathrm{~km}^{2}$, na divisa dos estados do Ceará, Pernambuco, Piauí e Paraíba (Fig. 5.1). É constituída em sua quase totalidade por rochas mesozóicas. Por outro lado, a Formação Cariri compreende por arenitos grossos/conglomerados localizados na porção NE da região da Bacia, que representariam os restos de um extenso sistema fluvial entrelaçado de uma antiga bacia Paleozóica, ocupando uma grande área do paleocontinente Gondwana (Medeiros et al, 1997). A Bacia do Araripe integra o conjunto geotectônico informalmente referido como "bacias interiores do Nordeste". Estes depósitos apresentamse fortemente controlados pelas estruturas do embasamento Pré-Cambriano/Eo-Paleozóico, reativadas ao longo do Fanerozóico, especialmente durante os eventos tafrogênicos do Cretáceo Inferior, que culminaram com o rifteamento do Gondwana e a abertura do Oceano Atlântico Sul (Brito Neves, 1990). Das diferentes estratigrafias propostas para a região (Fig. 5.2), adotaremos a coluna proposta por Assine (1990) (Fig 5.3). 


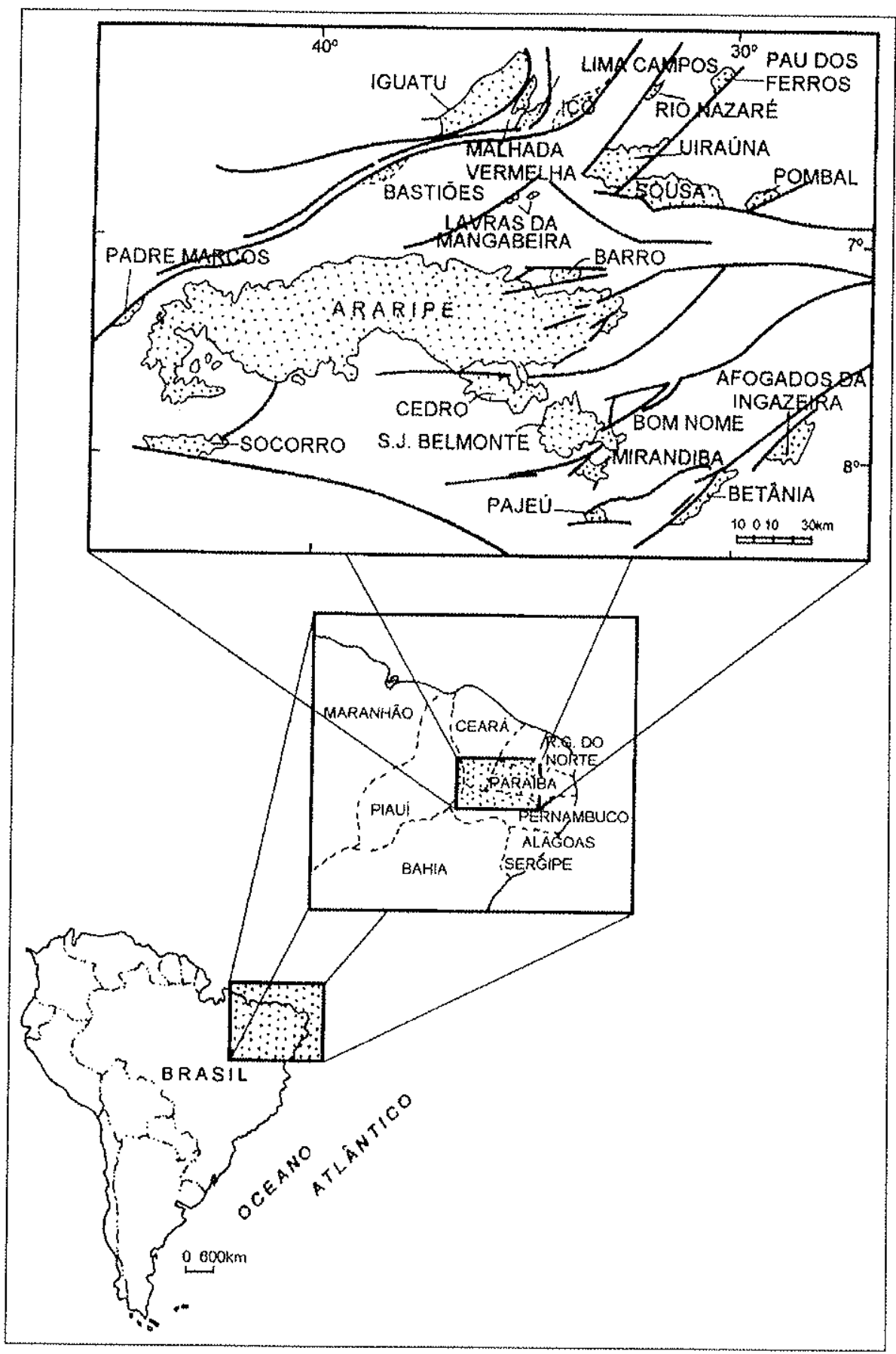

Figura 5.1 - Localização geográfica da Bacia do Araripe e de algumas outras bacias interiores do Nordeste (Modificada de Carvalho, 2000). 


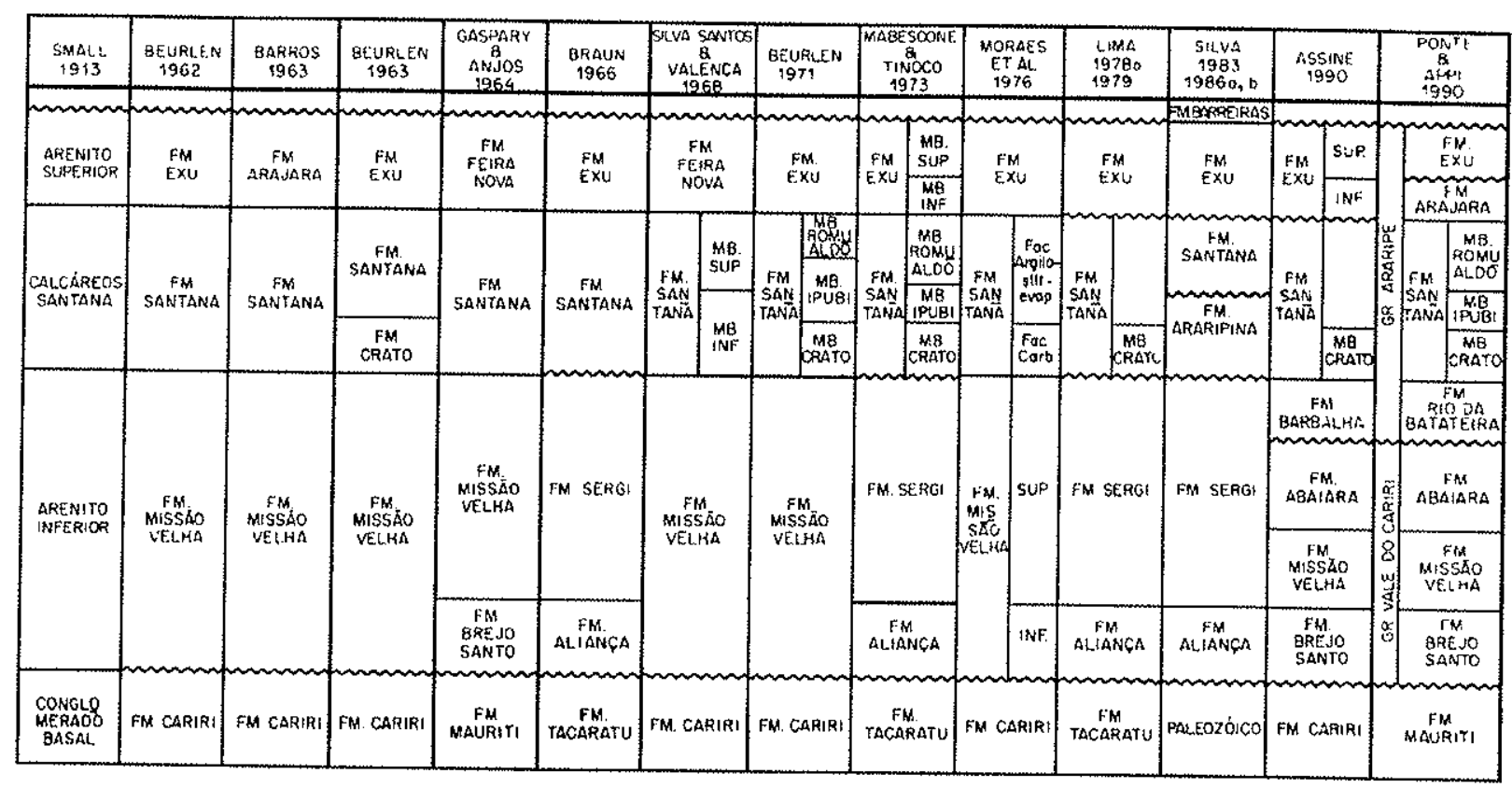

Figura 5.2 - Quadro comparativo das propostas de colunas estratigráficas da Bacia do Araripe (Extraída de Assine, 1992)

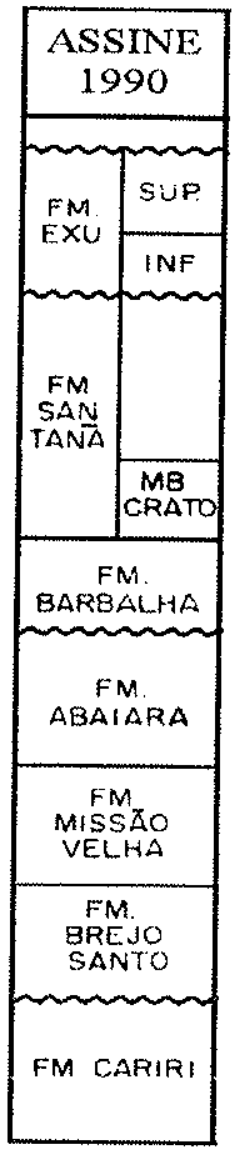

Figura 5.3 - Coluna estratigráfica da Bacia do Araripe proposta por Assine (1990) (Modificada de Assine 1992). 
A Formação Cariri foi descrita pela primeira vez em 1913 por Small, como arenito conglomerático sem nomeá-la. Esta formação só veio a ser denominada muitos anos depois por Beurlen (1962) com o nome de Cariri. Seu localmtipo ocorre nas proximidades da cidade de Mauriti (Gaspari \& Anjos, 1964). É composta de quartzo-arenitos conglomeráticos, oligomíticos, de coloração branca, cinza e amarelada muitas vezes silicificados. Estes arenitos são imaturos, de granulação média a grossa, feldspáticos a caolinitizados e estratificações cruzadas acanaladas e/ou tabulares. Feitosa (1987) descreve três fácies para estas rochas, fácies $\mathrm{A}$ - arenitos conglomeráticos com estratificação cruzada acanalada de grande e médio porte, fácies $\mathrm{B}$-arenitos médios a grossos com estratificação cruzada acanalada de médio e pequeno porte, e fácies $\mathrm{C}$ - arenitos conglomeráticos em lobos sigmoidais. A sua espessura varia entre 20 a $50 \mathrm{~m}$ (Beurlen, 1962).

A idade da Formação Cariri ainda é controvertida. Em geral a idade desta formação tem sido atribuída ao Paleozóico (Assine, 1990; Ponte, 1992; Ponte et al., 1997), oscilando entre o Siluriano (Ghignone, 1979) e Devoniano (Braun, 1966; Ghignone, 1972), baseado principalmente nas correlações da Formação Cariri com o Grupo Serra Grande da Bacia do Parnaíba (Ghignone, 1972) e com a Formação Tacaratu da Bacia Tucano-Jatobá (Braun, 1966). Berthou (1990), no entanto, sugeriu uma idade Jurássico Superior à Cretáceo Inferior, baseado em correlações com bacias brasileiras e africanas do mesmo tipo. Em 1994 Berthou relacionou a Formação Cariri com os processos de abertura do Oceano Atlântico Sul, sugerindo sua correlação com os estágios iniciais da Formação Afligidos da Bacia do Recôncavo, de idade Permiano-Triássicá.

Esta unidade foi considerada afossilífera até 1995, quando Carvalho et al. identificaram pegadas de dinossauros, em rochas supostamente desta formação. A ocorrência de icnofósseis de dinossauro descrita por Carvalho et al. (1995), de idade atribuída ao Cretáceo Inferior, vem reforçar os argumentos apresentados por Berthou (1990), criando dúvidas sobre a suposta idade paleozóica destes sedimentos. A ocorrência destas pegadas apresenta alguns problemas como se verá ainda neste capítulo. 


\subsection{Ocorrência dos objetos analisados}

Os objetos aqui interpretados como icnofósseis ocorrem na localidade da cachoeira de Missão Velha, CE, cerca de $5 \mathrm{~km}$ a noroeste da cidade homônima (Fig. 5.4). Ali aflora a Formação Cariri, intensamente silicificada, ao longo do leito e às margens do Rio Salamanca na confluência com o Rio Batateiras. $O$ afloramento (Fig. 5.5) possui aproximadamente $80 \mathrm{~m}$ de comprimento, $50 \mathrm{~m}$ de largura e $15 \mathrm{~m}$ de altura. Este afloramento é amplamente conhecido devido ao seu fácil acesso, tendo sido citado por Small (1913) na primeira descrição destas rochas. Este afloramento típico da Formação Cariri pertence à fácies B de Feitosa (1987).

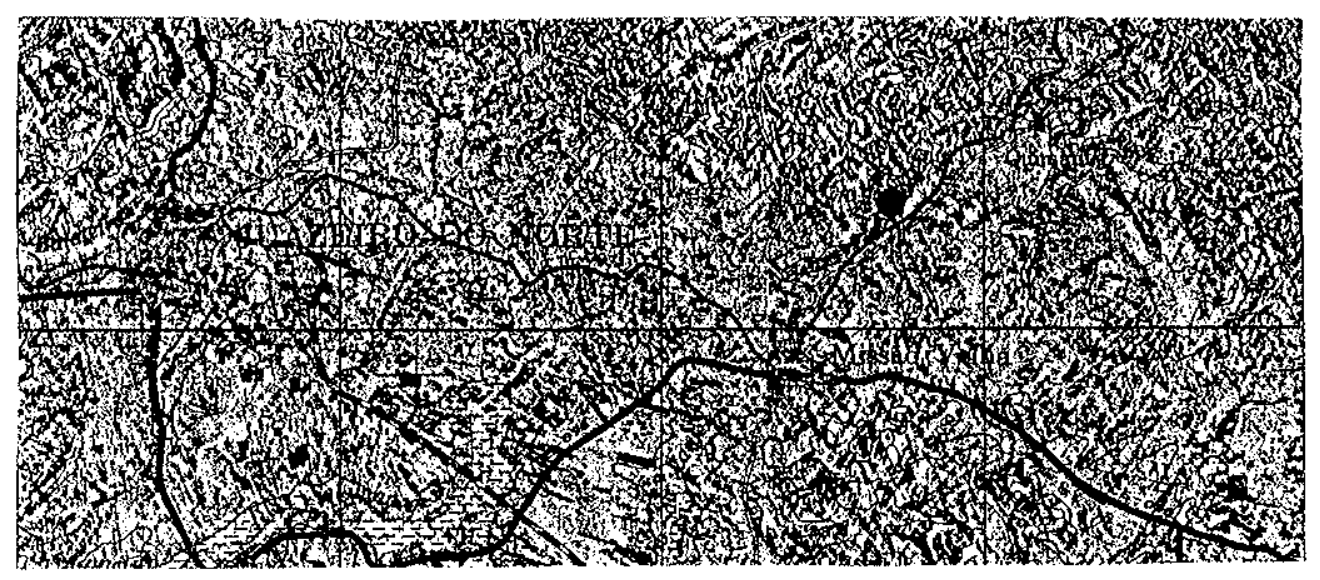

Figura 5.4 - Mapa de localização do afloramento.
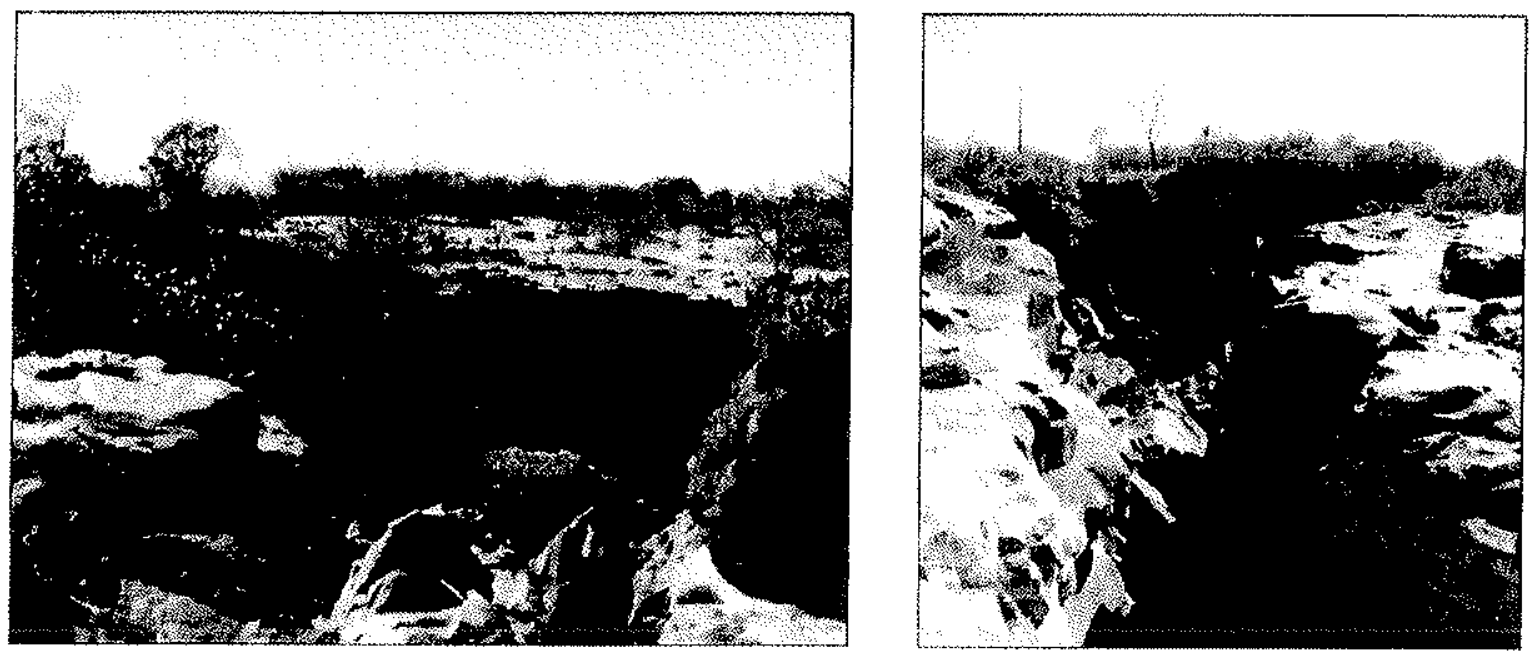

Figura 5.5 - Afloramento da Formação Cariri onde ocorrem os icnofósseis. 
Dentro desta grande exposição ocorre, na parte superior, um nível de arenito, exposto em uma área de cerca de $30 \mathrm{~m}^{2}$ com granulação de areia média a grossa, bastante silicificado, coloração amarelada, com $6 \mathrm{~cm}$ de espessura. O topo deste nível, de coloração marrom escura, apresenta abundantes sulcos e buracos que são aqui interpretados como icnofósseis (Fig. 5.6).

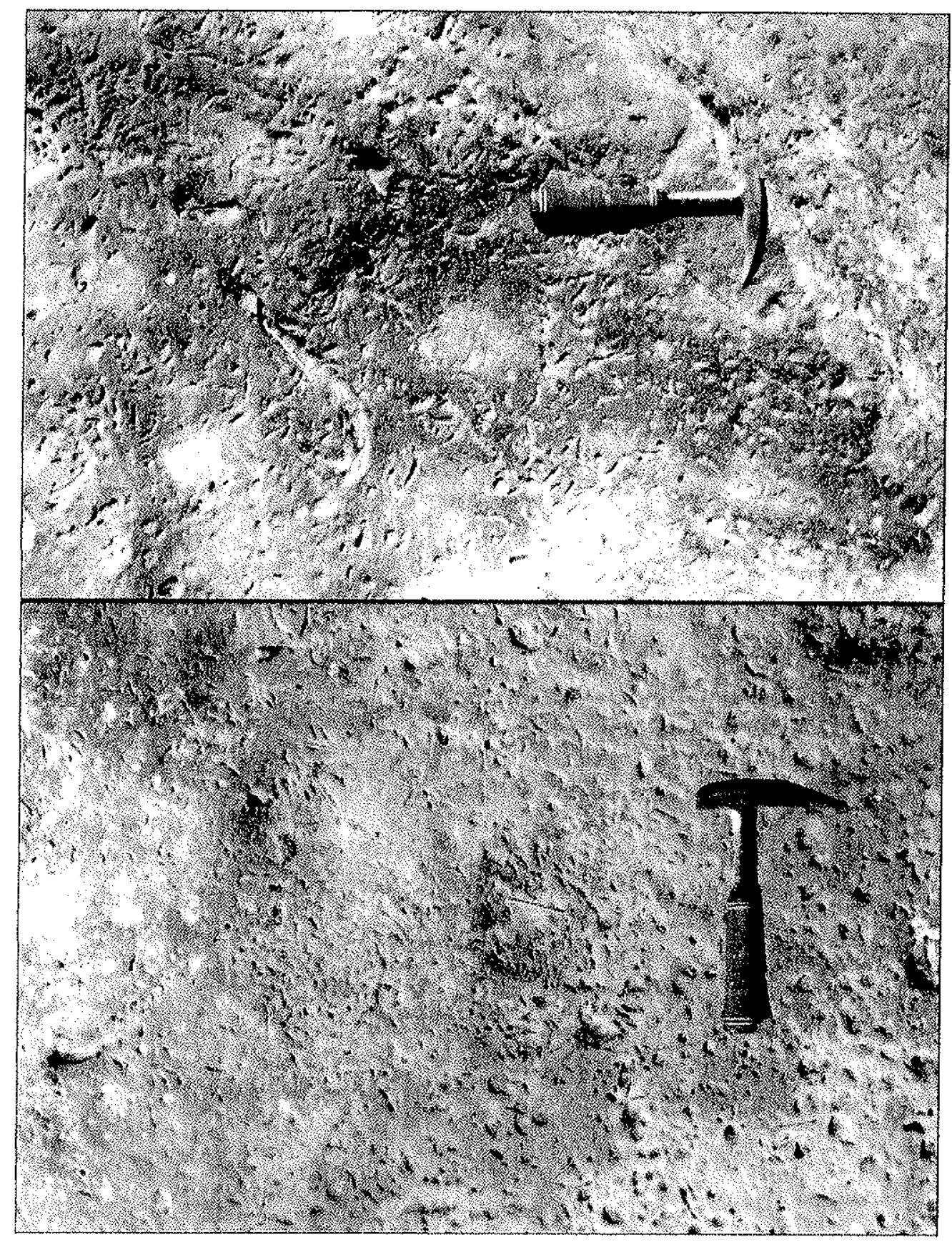

Figura 5.6 - O pavimento onde ocorrem os icnofósseis. O cabo do martelo está orientado em direção ao norte magnético. 


\subsection{Descrição litológica da amostra}

Uma amostra coletada deste nível revelou um arenito de granulação média, mal selecionado (areia fina a areia muito grossa), com grânulos e raros seixos pequenos (até $1,5 \mathrm{~cm}$ em dimensão maior). Os grãos são subangulosos a arredondados. Compostos predominantemente de quartzo (leitoso nos grânulos e pequenos seixos; incolor e transparente nas areias). Apresenta também feldspato (opaco, creme, branco, às vezes caolinitizado), minerais opacos e alguns fragmentos de rocha. Os seixos e grânulos não estão concentrados em níveis definidos, embora pareçam ser mais comums na metade superior da amostra. A matriz é esparsa, pouco abundante $(\leq 2 \%)$, argilosa, amarela e vermelha (cores de óxidos). A cimentação ocorreu por sobrecrescimento epitaxial nos grãos de quartzo, revelado pela presença de faces cristalinas evidentes em poros apenas parcialmente preenchidos e pela continuidade cristalográfica evidente petrograficamente de baixo de nicóis cruzados. Óxido de $\mathrm{Mn}$ (inferido pela cor preta) recobre parcialmente algumas destas faces cristalinas. Estratificação/laminação interna não é evidente nesta amostra.

A análise petrográfica das lâminas confeccionadas a partir desta amostra confirmou as observações macroscópicas já descritas. Nesta análise constatou-se a presença dominante de quartzo (monocristalino, policristalino, com extinção ondulante), com presença significativa de feldspato (às vezes caolinitizado) e fragmentos de rocha, e mais raramente minerais acessórios e minerais pesados. A matriz é escassa e a cimentação por sílica foi intensa.. Esta descrição não apenas é coerente com o que Feitosa (1987) descreveu como típica da fácies B como também coincide com a caracterização da Formação Cariri no Léxico Estratigráfico (Baptista et. al., 1980). Isto, mais a localização da ocorrência em local clássico mencionado por Small (1913), não deixa dúvidas de que a amostra provém, de fato, da Formação Cariri. 


\subsection{Métodos utilizados}

Os objetos de suposta origem biogênica foram examinados e fotografados no campo e analisados e medidos no laboratório com lupa binocular de uma amostra (Fig. 5.7 e Fig. 5.8) de aproximadamente $270 \mathrm{~cm}^{2}$ de área por $6 \mathrm{~cm}$ de espessura. As observações foram completadas em cortes transversais, em moldes em látex (Fig. 5.8) e em três lâminas petrográficas confeccionadas a partir da amostra. Fotos de campo foram utilizadas para analisar a orientação destes objetos.

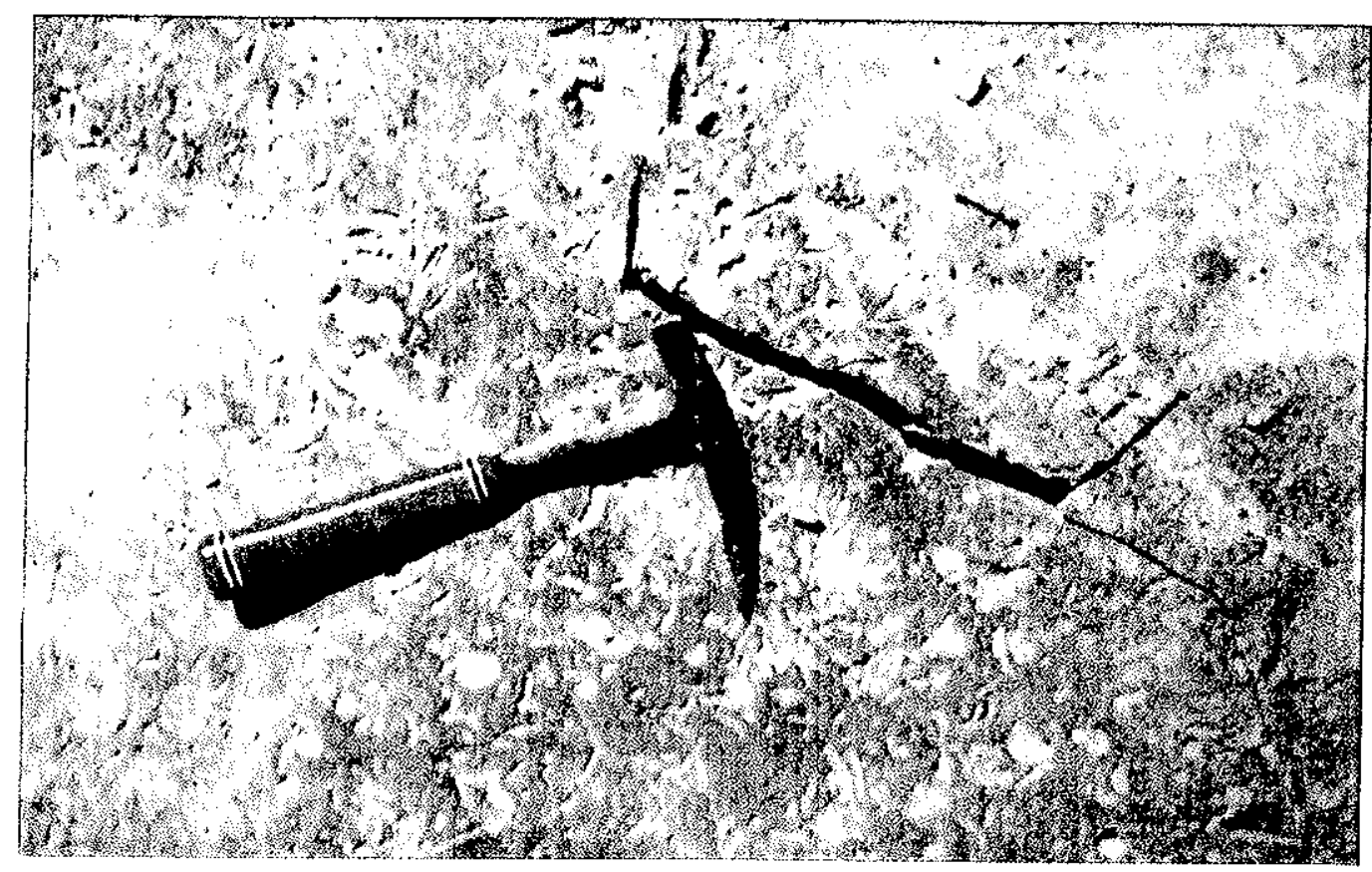

Figura 5.7 - A amostra estudada, logo acima e à direita do martelo, no momento da coleta. O cabo do martelo indica o norte magnético. 


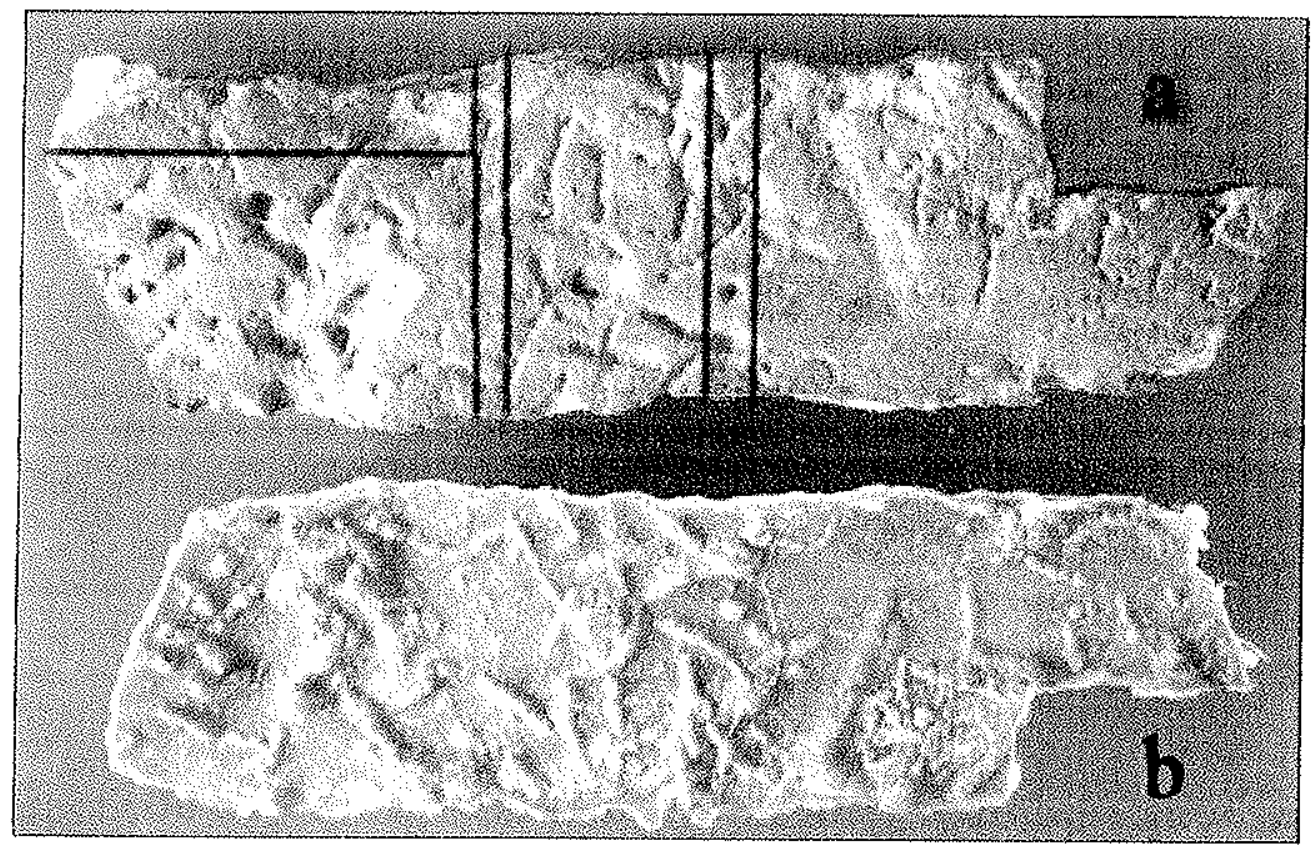

Figura 5.8 - (a) Detalhe da amostra no laboratório. As linhas pretas indicam os locais onde a amostra foi serrada para análise dos objetos. (b) $\mathrm{O}$ molde em látex da superfície da amostra. $(\times 0,4)$.

\subsection{Caracterização dos objetos}

Os objetos analisados ocorrem abundantemente em uma área exposta do leito do rio de aproximadamente $30 \mathrm{~m}^{2}$ que normalmente encontra-se recoberta por suas águas. Sua descoberta devell-se à forte seca que afetou a região em 1998.Distinguem-se três formas de objetos de possível origem biológica. Formas 1 e 3 ocorrem em epirrelevo côncavo e forma 2 ou em relevo completo. As formas mais abundantes são a forma 1 (horizontal/subhorizontal) e a forma 2 (penetrante). A forma 3 é rara na amostra estudada, e aparentemente isto se reflete no afloramento, a julgar pelas fotos tiradas no campo. Entretanto, devido ao seu relevo mais suave, seu reconhecimento é mais dificil nestas fotos. As estruturas foram expostas pela ação de processos erosivos modernos que removeram o preenchimento de vários espécimes. Por meio de lupa, pode-se notar desde meros vestígios até a totalidade deste preenchimento. 
Formas 1 e 2 são facilmente identificáveis em cortes da amostra por seu preenchimento de partes aproximadamente iguais de areia fina e lama (silte/argila), esta tingida de amarelo. Comparada à areia da camada, a areia do preenchimento parece ser muito mais angulosa, variando de subarredondada a angulosa. A granulometria é mais fina do que na rocha, dificilmente ultrapassando a fração mais grossa da areia fina - 177 a $250 \mu \mathrm{m}$. Os grãos maiores ainda preservam contatos entre si, mas em menor número do que na rocha.. $\mathrm{O}$ preenchimento não apresenta evidências de Spreite, devendo ter ocorrido de modo passivo, provavelmente por infiltração da camada sobrejacente (não preservada na amostra e não observada no campo). As formas estão quase todas concentradas na metade superior da camada, apresentando contato abrupto com o sedimento sem nenhuma evidência de revestimento. Aparentemente parece haver uma passagem da forma 1 (horizontal/subhorizontal) para forma 2 (penetrante), pois estas formas interceptam-se em diversos pontos da amostra. Os objetos ainda apresentam um manto de alteração superficial, que esbranquece os termos finos do preenchimento (caolinitização?), enquanto a amostra em si apresenta uma película/zona fina marrom avermelhada de alteração superficial.

A forma 3 não apresenta preenchimento, revestimento, variações de granulação, nem relações diretas aparentes com as formas 1 e 2 . O número de espécimes presentes na amostra estudada é baixo, com apenas um único espécime maior. O restante dos espécimes tem seu comprimento segmentado pela superficie de quebra da amostra, não fornecendo informações significativas. Esta forma diferencia-se da forma 1 por seu baixo relevo, maior largura e ausência de preenchimento. 
Forma 1 - 51 traços suavemente curvos, alguns isolados, outros bifurcados, de 10 e $15 \mathrm{~mm}$ de comprimento, de 2 a $5 \mathrm{~mm}$ de largura e de 1 a $3 \mathrm{~mm}$ de profundidade, às vezes cruzandose ou interceptando-se (Fig.5.9).

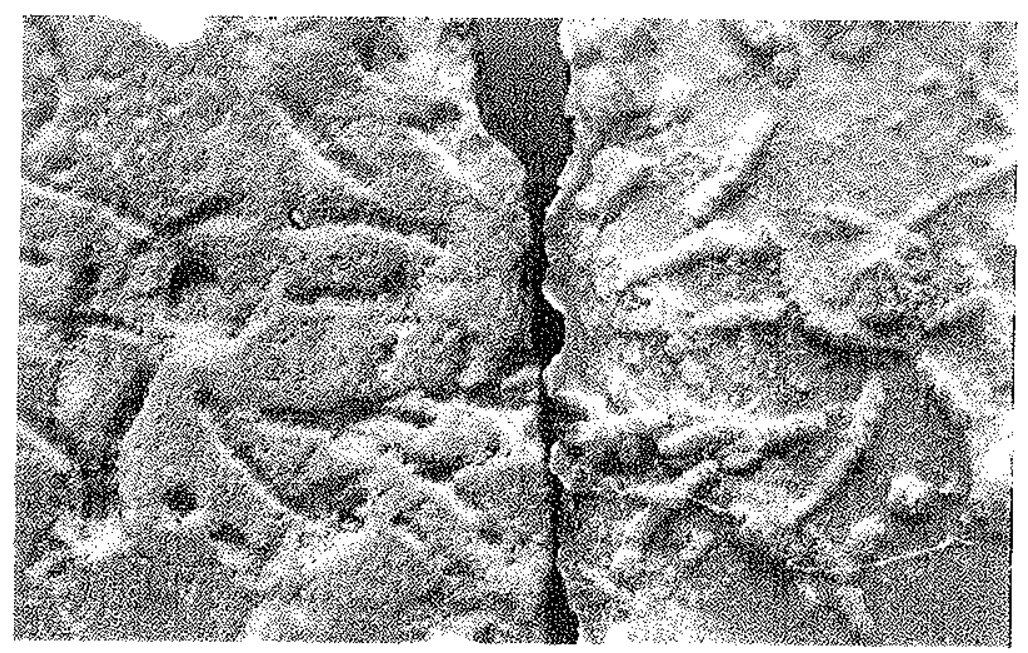

Figura 5.9 - Detalhe da amostra (à esquerda) e do molde em látex (à direita). Os traços lineares representam a Forma $1 \mathrm{e}$ as estruturas circulares a Forma $2(\times 0,6)$.

Forma 2 - 14 tubos preenchidos, representados na superfície da amostra por contornos circulares a elfpticos, com diâmetro entre 4 e $15 \mathrm{~mm}$. $O$ ângulo de penetração na rocha varia, de baixo ângulo a subvertical. Encontram-se geralmente interceptando traços da forma 1, mas também ocorrem isolados (Fig 5.10).

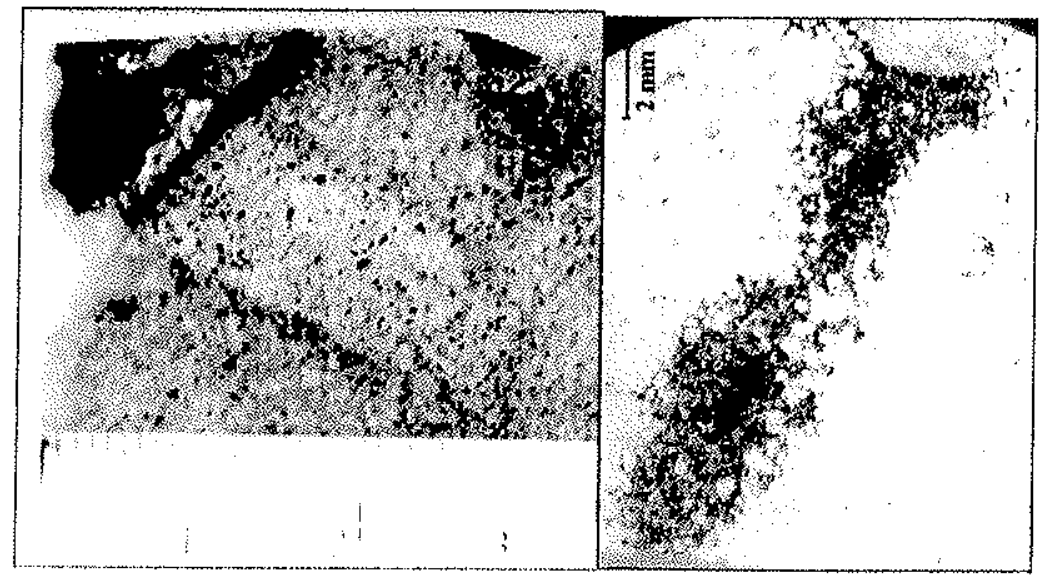

Figura 5.10 - Detalhes da Forma 2 em corte da amostra (à esquerda) e em lâmina (à direita). 
Forma 3 - 4 traços retos, de 30 a $65 \mathrm{~mm}$ de comprimento, achatados com largura entre 7 a $12 \mathrm{~mm}$ e profundidade entre 2 a $5 \mathrm{~mm}$, estes traços ocorrem isolados ou em contato com traços do primeiro tipo (Fig. 5.11).

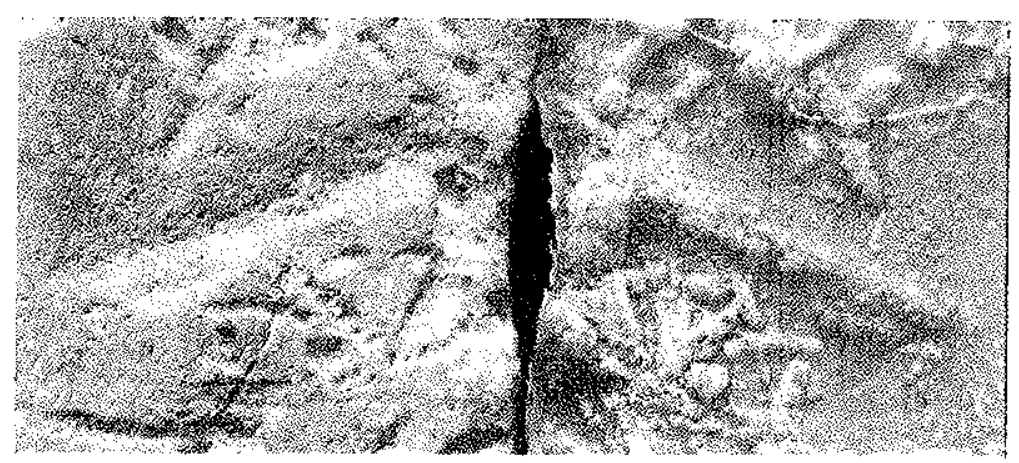

Figura 5.11 - Detalhe da amostra e molde em látex da Forma $3(x 0,7)$.

\subsection{Orientação dos objetos}

A partir de três fotografias de campo, com diferente grau de detalhamento, representando aproximadamente $1,8 \mathrm{~m}^{2}$ da laje, foi levantada a orientação destes objetos. A medição das direções dos objetos foram feitas com auxílio de um transferidor, e a divisão dos intervalos foi realizada de 15 em 15 graus com os 15 graus da direção E-W divididos em 7,5 graus para cada direção. Como pode ser visto nas figuras $5.12,5.13$ e 5.14 , o resultado não apresentou nenhuma direção preferencial estrita para estes objetos. Na Fig 5.12, de área maior os objetos parecem ter una orientação mais pronunciada para NW. Ao aumentarmos a magnificação, utilizando a Fig. 5.13, este pronunciamento da direção torna-se menos evidente. E na fotografia de área menor, Fig 5.14, não se observa nenhuma tendência preferencial. Esta variação nas direções e preferência para NW podem ser atribuídas à influência do ângulo de incidência dos raios solares sobre os objetos, destacando mais os objetos oblíquos a iluminação e mascarando outros, paralelos a iluminação. Este fator é minimizado quando se aproxima mais à superficie para detalhar os objetos. 


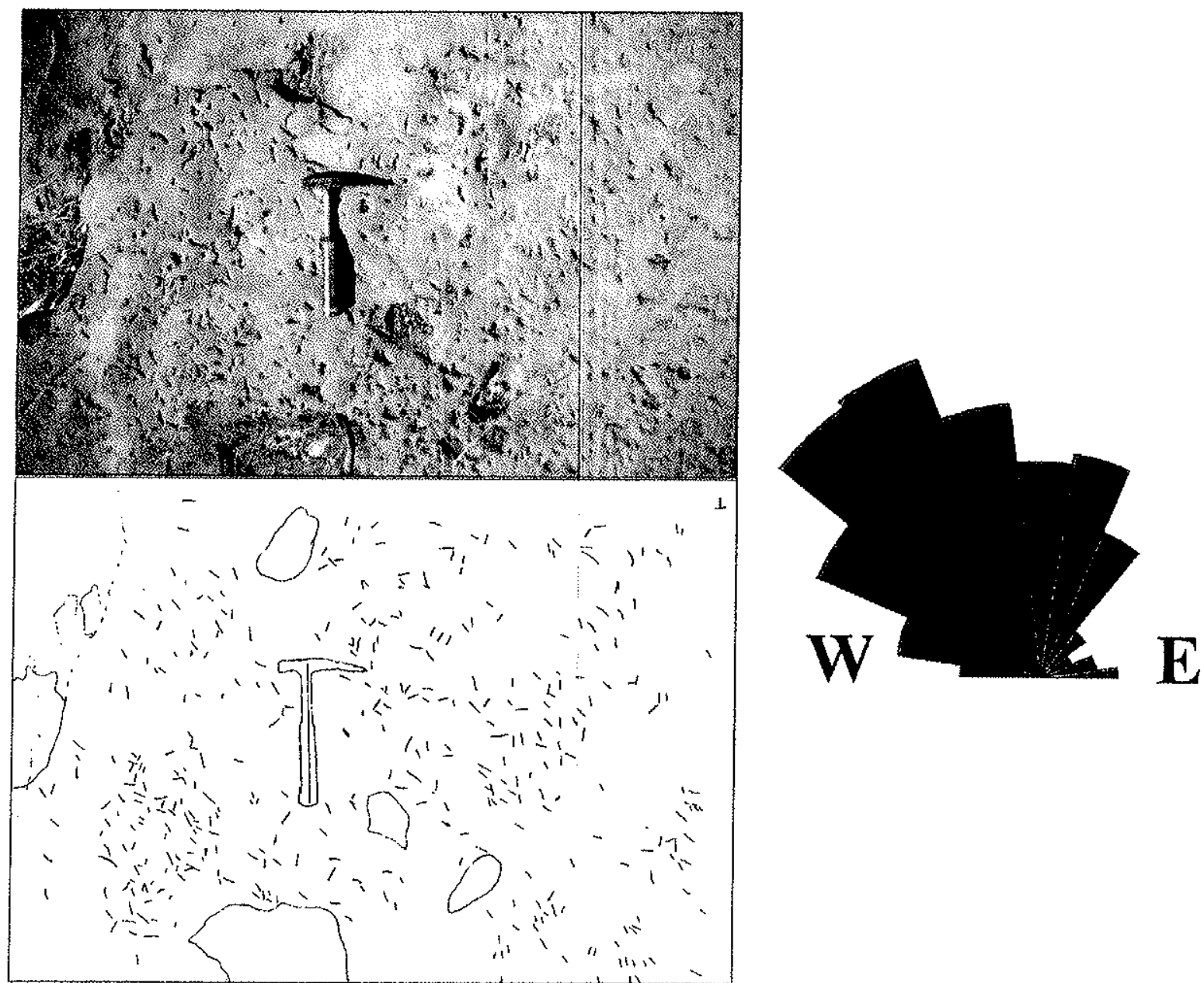

Figura 5.12 - Na parte superior, foto do pavimento de icnofósseis (cabo do martelo indica o norte magnético). Na parte inferior, desenho da direção dos icnofósseis baseado na foto. $\dot{\AA}$ direita, o resultado da análise de suas direções. 


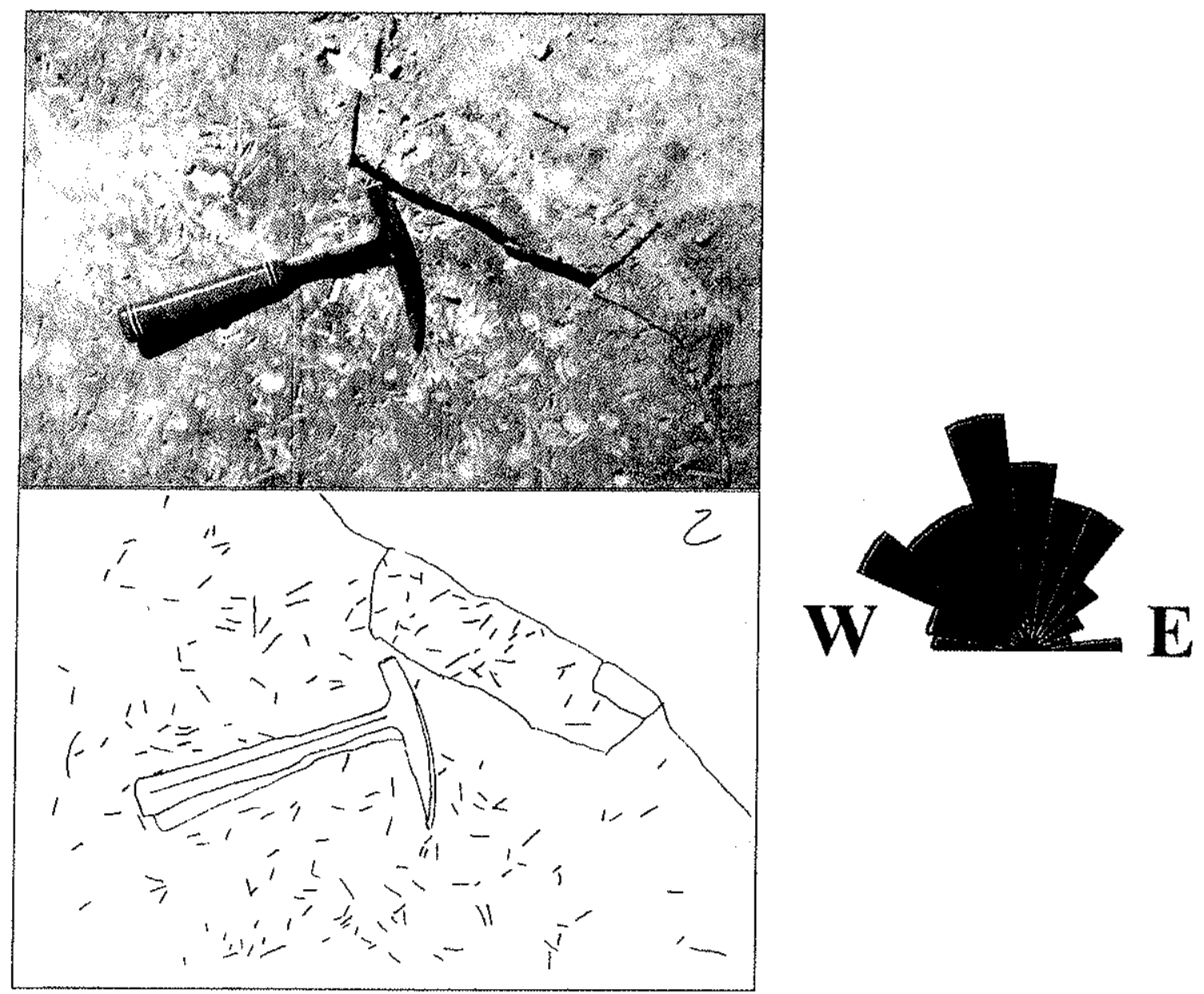

Figura 5.13 - Na parte superior, foto do pavimento de icnofósseis no local onde foi coletada a amostra (cabo do martelo indica o norte magnético). Na parte inferior, desenho da direção dos icnofósseis baseado na foto. À direita, o resultado da análise de suas direções. 


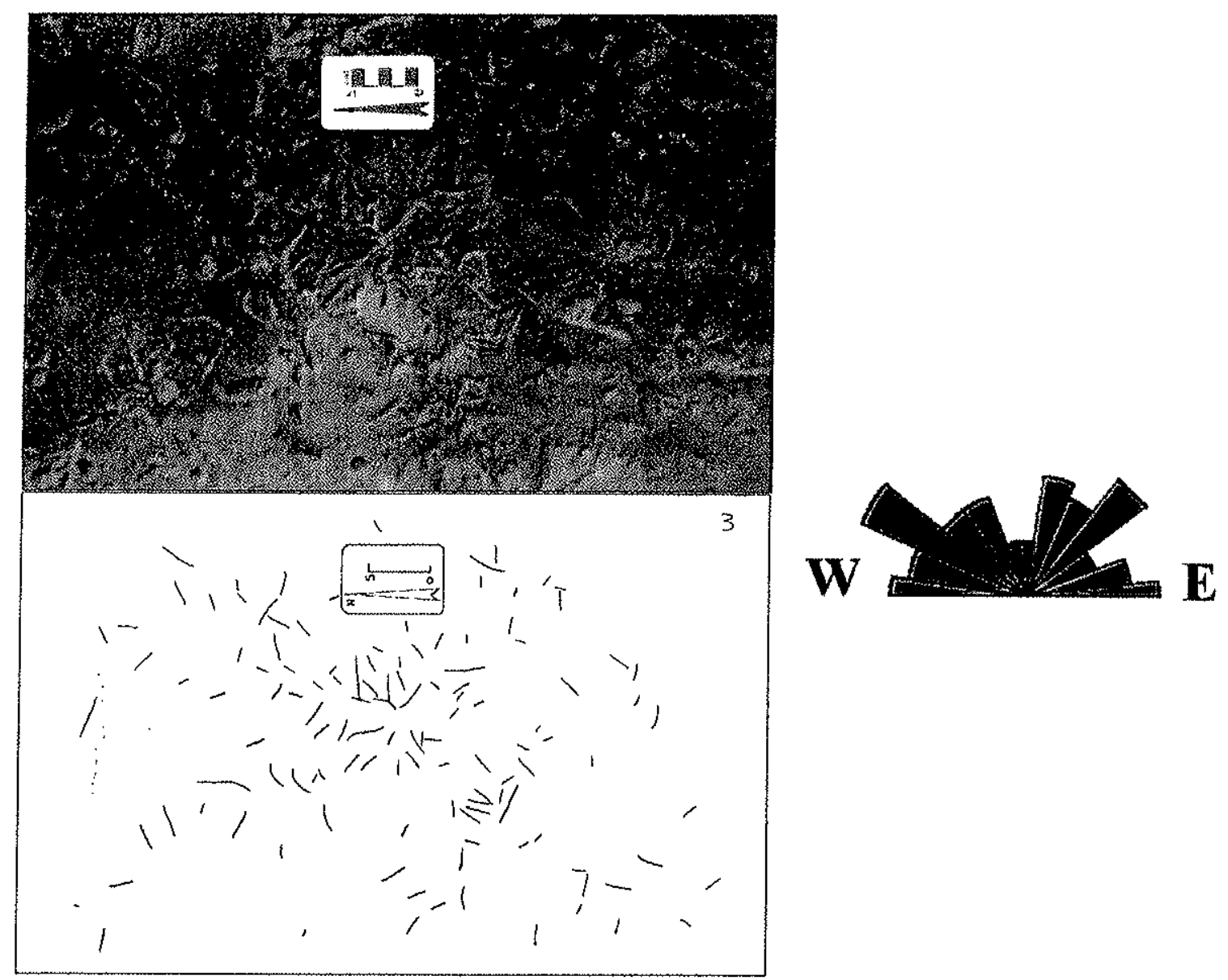

Figura 5.14 - Na parte superior, foto de detalhe do pavimento de icnofósseis (seta da escala indica o norte magnético). Na parte inferior, desenho da direção dos icnofósseis baseado na foto. À direita, o resultado da análise de suas direções.

\subsection{Discussão}

A biogenicidade dos objetos estudados foi comprovada através da utilização dos seguintes critérios de Ekdale et al. (1984) e Pickerill (1994), já discutidos no capítulo 3: critério (a) tamanho e continuidade uniforme de estrutura individual, critério (b) ocorrência como forma geométrica regular complexa e repetitiva e critério (g) preservação em relevo completo. Adicionalmente, os objetos não se enquadram em nenhum dos critérios de origem não biogênica. Desta maneira, podem ser classificados, quanto à sua origem, com grau 7, objetos de origem biogênica, ou seja icnofósseis, de acordo com a escala numérica proposta no capitulo 3 . 
A comprovação destes objetos como icnofósseis tem grande significância paleontológica, pois é a primeira identificação de icnofósseis de invertebrados na Formação Cariri, que até pouco tempo atrás, era considerada como afossilifera. Esta descoberta ganha proporções maiores caso a idade da formação seja realmente devoniana. Beerbower (1985), por exemplo, descreve as mudanças consideráveis acontecidas neste periodo decorrentes da conquista dos continentes por parte dos animais e plantas. É possivel portanto que estes icnofósseis sejam testemunhos desta importante fase da história evolutiva do planeta, tomando-se parte do crescente registro de icnofósseis continentais deste periodo.

Por outro lado, Carvalho et al. (1995) registraram pegadas de dinossauros em rochas supostamente da Formação Cariri. A classificação e idade destes fósseis é indiscutível, mas a localização geográfica (e consequientemente a posição estratigráfica) desta descoberta é pouco precisa. Na Fig. 1 de Carvalho et al. (op. cit.), o afloramento das pegadas, com apenas 5,5 metros de espessura, é assinalado no mapa geológico da Bacia do Araripe por uma marca correspondendo a $10 \mathrm{~km}$ de diâmetro e a uma área de aproximadamente $78 \mathrm{~km}^{2}$. Estratigraficamente, o afloramento é descrito no título da Estampa 1 como "Formação Missão Velha (ou Tacaratu)", mas também é atribuido à "Formação Missão Velha (ou Formação Tacaratu, Formação Mauriti, Formação Cariri)". Estes termos litoestratigráficos, como visto no início deste capítulo, não representam uma só formação: a Formação Missão Velha faz parte da Bacia do Araripe, mesozóica, enquanto os outros termos se referem a unidases anteriores à instalação desta bacia em nossa opinião. Carvalho et al. (op. cit.) também foram equivocados ao adotarem as litofácies A, B e C definidas por Feitosa (1987) para a Formação Cariri, com definições diferentes das originais. Desta forma, até que a localização geográfica e estratigráfica das pegadas dos dinossauros possa ser esclarecida se ocorrem de fato na Formação Cariri, ou, como é nossa suspeita, na Formação Missão Velha - a suposta idade mesozóica da Formação Cariri, bem como as interpretações geotectônicas, estratigráficas e paleogeográficas alegadas por Carvalho et al. $(1995,2000)$ baseadas nesta afirmação, nos parecem precariamente fundadas.

Devido à forma simples destes icnofósseis, sua descoberta não oferece, de imediato, grande auxilio na solução do problema estratigráfico e cronológico da Formação Cariri. No 
entanto, a sua descoberta revela a presença indubitável de fósseis nesta formação e pode servir como uma ferramenta extra na correlação das formações similares de bacias próximas. Carvalho et al. (1995) já ilustraram, por exemplo, icnofósseis de invertebrados na Formação Sousa da Bacia de Sousa (Fig. 5.15) semelhantes aos descritos aqui. A questão da idade permanece, pois, em aberto.

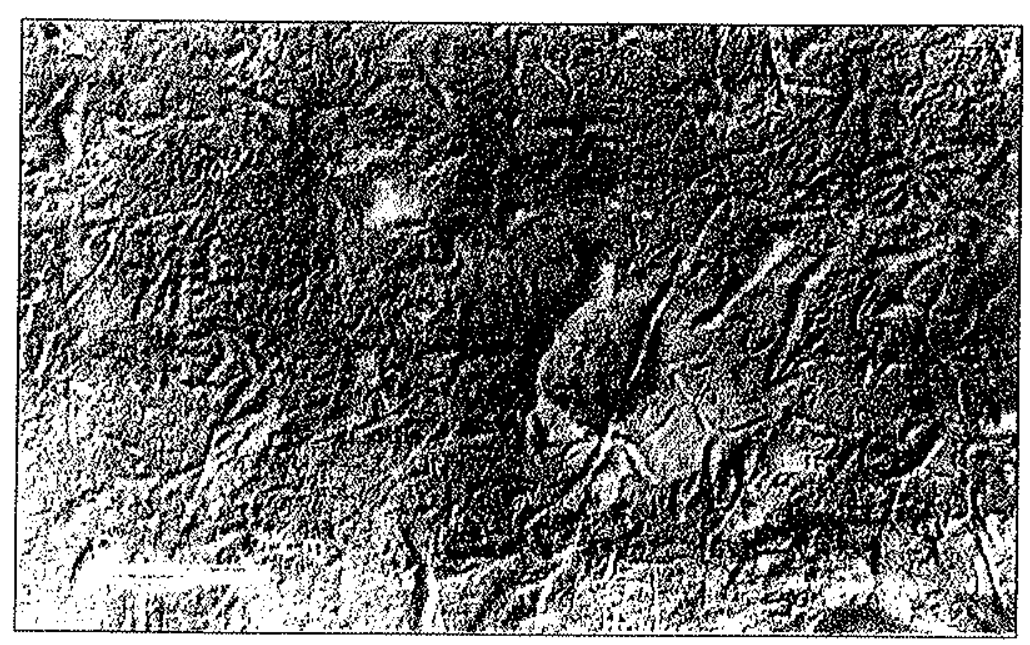

Figura 5.15 - Icnofósseis invertebrados da Formação Sousa (Extraída de Carvalho, 2000).

Os icnitos pertencentes às formas 1 e 3 são provavelmente de organismos vermiformes e se assemelham aos icnogêneros Planolites ou Palaeophycus. A distinção entre estes dois icnogêneros tem sido motivo de discussão. Alpert (1975) diferenciou Planolites de Palaeophycus baseado na presença, em Palaeophycus, de ramificações e na ausência desta feição em Planolites. Pemberton \& Frey (1982) discutiram amplamente este problema a partir das definições originais e do estudo das espécies-tipo destes icnogêneros. Descobriram que quase metade das espécies-tipo estavam desaparecidas, tendo sido estudadas, nestes casos, através de fotografias, desenhos e descrições originais. Chegaram às seguintes conclusões: a) Tanto Planolites como Palaeophycus podem apresentar ramificações, embora não muito freqüentes; b) O preenchimento presente no icnogênero Palaeophycus é similar ao da rocha encaixante, enquanto o preenchimento do icnogênero Planolites tende a diferir do material circundante. Contudo, Hallam (1975) tinha sugerido que eventualmente o preenchimento do icnogênero Palaeophycus pode diferir do da rocha mãe, quando em contato com camada sobrejacente de composição diferente e preenchidos 
por estes sedimentos; c) Palaeophycus é definido como uma toca com revestimento material aplicado à parede da toca por seu ocupante ou material passivamente acumulado por aderência na parede da toca enquanto estava aberta (Bromley, 1990) - preenchida por sedimentos tipicamente idênticos aos da rocha matriz. Palaeophycus é o resultado de uma sedimentação passiva em uma toca de habitação construída por um organismo suspensívoro ou predador; d) Planolites é definido como um icnito sem revestimento, preenchido por sedimentos diferentes, em textura e/ou composição, daqueles presentes na rocha matriz. Planolites é o resultado de um preenchimento ativo realizado por organismos detritivoros.

Apesar de os icnitos horizontais assemelharem-se aos icnogêneros Planolites ou Palaeophycus, Formas 1 e 3 divergem das definições clássicas destas icnogêneros, no caso da Forma 3, devido à ausência de preenchimento e por aparentar um comportamento de deslocamento (Repichnia). Planolites é considerado um icnito de alimentação (Fodinichnia) e Palaeophycus um icnito de habitação (Dominichnia). Forma 1, possui preenchimento $\mathrm{q}$ diferente da rocha mãe (como em Planolites), mas parece ter sido depositado passivamente (como em Palaeophycus). Também não há estruturas de revestimento características de Palaeophycus. O comportamento desta forma, do mesmo modo da Forma 3, é provavelmente de deslocamento (Repichnia). Portanto, Formas 1 e 3 dificilmente se enquadram nestes icnogêneros.

A disposição de Forma 1 na amostra sugere uma relação genética com a Forma 2 -- icnitos em forma de tubos possivelmente de habitação (Dominichnia). Possivelmente Forma 1 representa uma mudança de comportamento do mesmo organismo gerador da Forma 2. Este organismo habitava a Forma 2 e, ao entrar e sair de sua habitação, deixou as evidências deste deslocamento impressas como Forma 1. O conjunto destes icnofósseis é similar a icnitos do Paleogeno da China (Fig. 5.16) (Fouch \& Dean, 1982) formados por animais desconhecidos. 


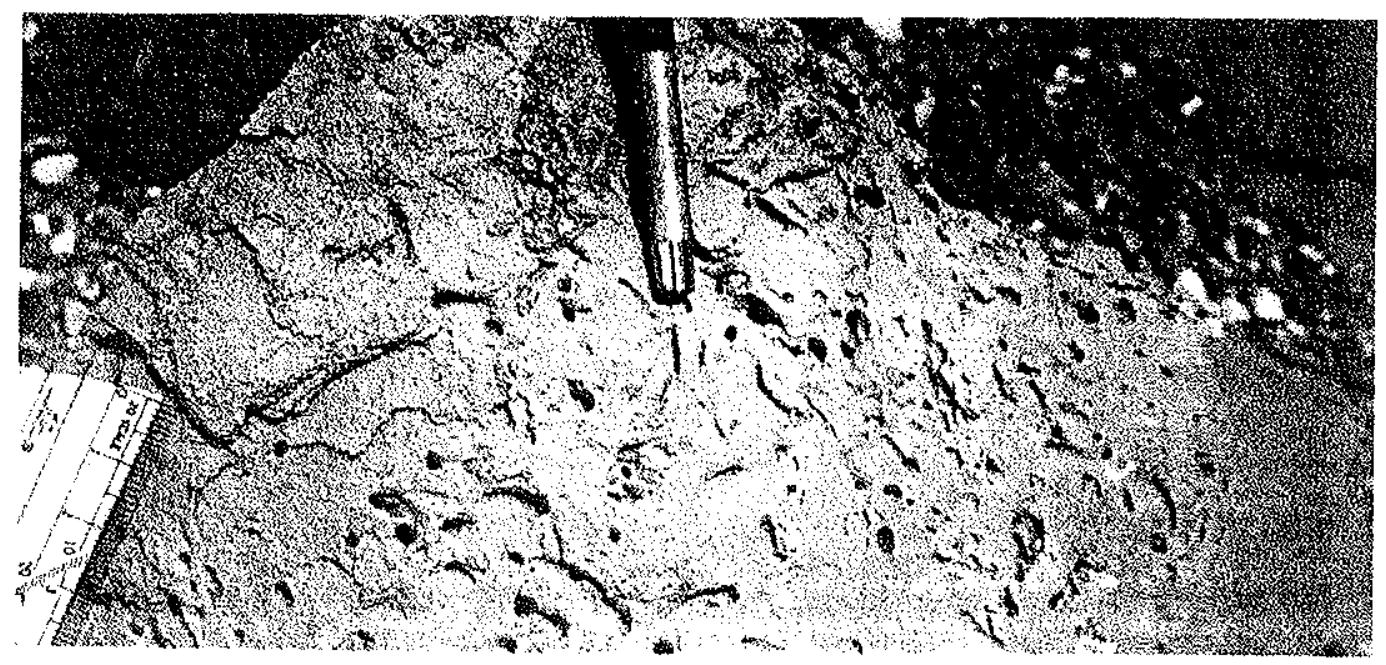

Figura 5.16 -- Icnitos parecidos com Formas 1 e 2 atribuídos a animais não identificados do Paleogeno da China. (extraído de Fouch \& Dean, 1982).

Os organismos geradores das três formas devem ter sido organismos bentônicos vágeis, simples, vermiformes e sem apêndices. O tempo de habitação destes organismos na camada estudada não parece ter sido muito longo, pois o grau de bioturbação da camada é baixo. $O$ ambiente na época da geração dos icnitos deve ter sido de águas mais calmas do que na época da deposição da rocha mãe, caso contrário eles teriam sido destruidos pela ação da corrente ou apresentariam movimentação pela deposição de novos sedimentos sobre o substrato habitado. $O$ substrato deveria ter sido suficientemente firme para conservar estas formas sem que ocorresse o colapso de suas paredes. E o preenchimento das formas parece ter sido posterior, em um único episódio, com contribuição de material significativamente mais fino do que na época da sedimentação original, talvez por uma mudança no regime de fluxo na migração de canal ou na variação no suprimento de sedimento ao rio. 


\section{Os supostos icnofósseis do Grupo Alto Paraguai}

\subsection{Introdução}

A definição do Grupo Alto Paraguai ainda é motivo de controvérsias no meio geológico, devido em boa parte ao fato de trabalhos mais recentes sobre esta questão serem da década de 80 (Del'Arco et al.,1982, Almeida, 1984, Alvarenga, 1984 e 1986). Desde que Almeida (1964) definiu o grupo originalmente, diversas propostas estratigráficas regionais já foram sugeridas (Fig. 6.1). Uma vez que não é objetivo desta pesquisa discutíllas, será adotada a coluna estratigráfica simples proposta por Almeida (1984) (Fig. 6.2) com duas formações, a Formação Raizaina na base e a Formação Diamantino no topo.

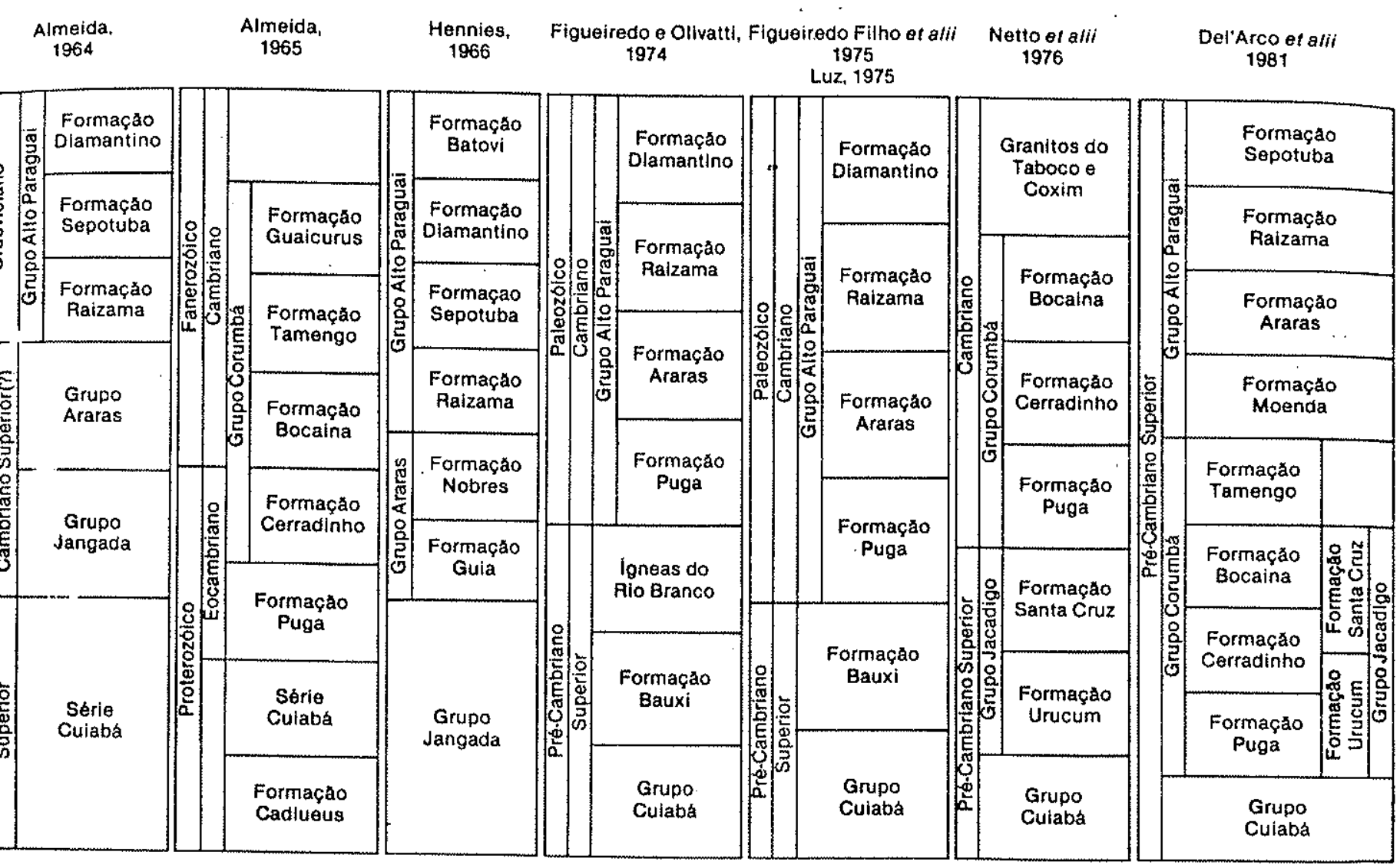

Figura 6.1 - Diferentes estratigrafia regionais propostas para a Faixa Paraguai (Extraida de Almeida, 1984). 


\begin{tabular}{|c|c|c|c|}
\hline \multicolumn{2}{|c|}{ Grupo } & \multicolumn{2}{|c|}{ Formaçăo } \\
\hline & & $\begin{array}{l}\text { Granito Săo } \\
\text { Vulcantcas d }\end{array}$ & $\begin{array}{l}\text { ite, } \\
\text { toso }\end{array}$ \\
\hline \multirow{2}{*}{\multicolumn{2}{|c|}{ 㞼 }} & \multicolumn{2}{|c|}{ Dlamantino } \\
\hline & & \multicolumn{2}{|c|}{ Ralzama } \\
\hline \multirow{3}{*}{\multicolumn{2}{|c|}{ 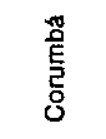 }} & Tamengo & \multirow{3}{*}{ 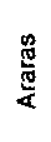 } \\
\hline & & Bocaina & \\
\hline & & Cerradinhe & \\
\hline & & \multicolumn{2}{|c|}{ Puga } \\
\hline & & \multicolumn{2}{|c|}{ Bauxt } \\
\hline \multirow{2}{*}{ 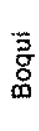 } & \multirow{2}{*}{ 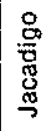 } & \multicolumn{2}{|c|}{ Urucum } \\
\hline & & \multicolumn{2}{|c|}{ Santa Cruz } \\
\hline \multicolumn{2}{|c|}{ Culabá } & & \\
\hline
\end{tabular}

Figura 6.2 - Coluna estratigráfica de Almeida (1984).

Os objetos analisados foram atribuidos à Formação Raizama do Grupo Alto Paraguai por M. F. Zaine (1991) que os coletou na região de Cáceres no Estado do Mato Grosso. Estes objetos encontram-se hoje depositados nas Coleçôes Paleontológicas do Instituto de Geociências da Universidade de São Paulo, IG-USP (Fig. 6.19). São todos muito simples e em sua grande maioria exemplares únicos. A maior parte destes objetos foi classificada por Zaine (1991) como icnofósseis, supostamente pertencentes aos icnogêneros Cochlichnus, Planolites, Lockeia e Palaeophycus, ou dubiofósseis. O resto do material coletado por Zaine, mas não descrito em sua tese, aparentemente, foi considerado por ela como estruturas sedimentares abiogênicas e pseudofósseis. Estes espécimes também serão discutidos neste capitulo.

\subsection{Contexto Geológico}

A Formação Raizama é constituida, segundo Olivatti (1981), por arenitos brancos e róseos, quartzosos, com finos níveis conglomeráticos e arenitos feldspáticos, apresentando estratificações cruzadas, marcas onduladas e, localmente, intercalações síltico-argilosas de cores avermelhadas. A espessura da Formação Raizama é variável, sendo estimada por Almeida (1964) em cerca de $1.600 \mathrm{~m}$. Outras estimativas, entre 120 e $860 \mathrm{~m}$ de espessura, foram feitas por Vieira (1965) enquanto Figueiredo \& Olivatti (1974) estimaram espessuras 
entre 200 e $600 \mathrm{~m}$. Sua maior espessura é na Serra do Tombador, decrescendo em direção as extremidades da Faixa Paraguai.

A Formação Diamantino em sua porção inferior é constituida predominantemente de pelitos, com algumas intercalações de arcóseos finos avermelhados, verdes ou cinza claros. Na sua porção superior, apresenta arcóseos maciços avermelhados, estratificações planoparalelas são comumente observadas nos sedimentos mais finos e estratificações cruzadas nos arcóseos (Olivatti, 1981). A espessura da formação foi estimada em cerca de $900 \mathrm{~m}$ para a seção predominantemente pelítica (Almeida, 1964) e em $3.000 \mathrm{~m}$ para parte superior dentro da área cratônica (Hennies, 1966).

As formações Raizama e Diamantino representam uma seqüência regressiva com contato gradacional. Sua deposição em ambiente marinho costeiro, de águas rasas, sujeitas a ação de correntes mas também com áreas de deposição pelítica (Formação Raizama), evoluindo até uma deposição francamente continental (Formação Diamantino) (Almeida, 1964; Vieira, 1965; Figueiredo \& Olivatti, 1974). Parece haver uma zona de interdigitação entre as duas formações onde ocorrem as litologias típicas em ambas, tornando a definição do limite entre elas, às vezes, arbitrário (Almeida, 1984).

As datações já realizadas no Grupo Alto Paraguai são poucas e foram realizadas utilizandose quatro amostras de folhello da parte inferior da Formação Diamantino (Membro Sepotuba), datadas pelo método $\mathrm{Rb} / \mathrm{Sr}$ em rocha total. Cordani et al. (1978) obtiveram, inicialmente, uma idade de $547 \pm 5 \mathrm{Ma}$ com razão inicial ${ }^{87} \mathrm{Sr} /{ }^{86} \mathrm{Sr}$ de 0,7109 . Recalculadas posteriormente, estas idades foram e reajustadas para $569 \pm 20 \mathrm{Ma}$, mantendo-se a mesma razão inicial. Esta idade foi interpretada por Cordani et al. (1985) como correspondente a um evento anquimetamórfico. Neste mesmo trabalho, Cordani et al. (op. cit.) apresentaram nova datação, obtida a partir de 10 amostras da Formação Diamantino, de $660 \pm 60 \mathrm{Ma}$ com razão inicial ${ }^{87} \mathrm{Sr} /{ }^{66} \mathrm{Sr}$ de 0,7082 . Eles interpretaram esta idade como "uma aproximação da idade de sedimentação", mas expressaram, mais adiante no mesmo parágrafo, uma preferência para uma idade "em torno de $600 \mathrm{Ma}$ ou ligeiramente mais velha para este evento (Cordani et al., 1985, p.267)". 
Baseados em dados paleontológicos, estratigráficos e geocronológicos, Alvarenga \& Trompette (1992) sugeriram que: a) o Grupo Cuiabá e a Formação Puga seriam Vendiano Inferior ou Varangeriano (610-590 Ma); b) a Formação Araras seria Vendiano Superior ou Ediacariano; c) e, o Grupo Alto Paraguai seria Vendiano Superior e/ou Cambriano Inferior. Dados preliminares da tese de doutoramento de A. C. R. Nogueira (inf. verbal) demonstram una incursão negativa de isótopos de $\delta^{13} \mathrm{C}$ acima da Formação Puga, coerente com sua correlação à glaciação Varangeriana, como sugerido por Alvarenga \& Trompette (op. cit.).

Na porção sul da Faixa Paraguai, Zaine (1991) identificou um conjunto de fósseis na Formação Tamengo, parte superior do Grupo Corumbá, incluindo acritarcas, os metazoários Corumbella werneri e Cloudinalucianoi, este último considerado um fóssil-guia do Neoproterozóico terminal (Grant, 1990), e a metáfita Tyrasotaenia sp. (uma alga eucariótica do Vendiano Terminal/Cambriano Inferior), que assegura a posição estratigráfica desta formação na transição Pré-Cambriano/Cambriano. Se for admitida a equivalência da Formação Tamengo no Mato Grosso do Sul, ao topo ou acima da Formação Araras no Mato Grosso, que parece razoável em vista dos dados isotópicos de carbono de Boggiani (1997), torna-se bem plausível imaginar os sedimentos do Grupo Alto Paraguai se depositando em torno do limite Pré-Cambriano/Cambriano, talvez na sua maioria (ou totalmente), durante o Cambriano.

Assim sendo, os dados radiométricos, sugerindo sedimentação pré-vendiana e anquimetamorfismo ediacariano para a parte superior do Grupo Alto Paraguai não coadunam com os argumentos estratigráficos, isotópicos e bioestratigráficos. Há de se lembrar, porém, que a datação de rochas pelíticas pelo método $\mathrm{Rb} / \mathrm{Sr}$ em rocha total basease em alguns pressupostos teóricos, como a homogeneização isotópica do estrôncio nos sedimentos, dependente do intemperismo, distância da área fonte, tempo de residência e condições sedimentológicas no ambiente de sedimentação, halmirólise e diagênese precoce (Mizusaki et al., 1993), que nem todos os especialistas aceitam (ver discussão entre Vinogradov, 1996, e Gorokhov \& Mel'nikov, 1996). Ora, com a estratigrafia, mineralogia e sedimentologia do Grupo Alto Paraguai tão mal conhecidas, torna-se difícil atribuir um alto 
grau de confiança nas determinações radiométricas disponíveis, sendo mais plausivel uma idade vendiana superior ou cambriana inferior pela força dos argumentos isotópicos $\left(\delta^{13} \mathrm{C}\right)$ acusando uma idade pós-varangeriana.

\subsection{Avaliação dos objetos}

Os objetos aqui analisados estão depositados na coleção científica do Instituto de Geociências (IG) da Universidade de São Paulo (USP), registrados com os números GP/7E - 210 a 216 e GP/7E - 218 a 220 . Parte destes objetos foram estudados previamente por Zaine (1991) em sua tese de doutoramento (amostras GP/7E 211 a 216). Outros foram analisados pela primeira vez (amostras GP/7E 210 e 218 a 220).

Estes espécimes foram coletados em 1986 por Mariselma Zaine em três pontos distintos, descritos resumidamente mais adiante. Em quase todos os casos, com exceção de GP/7E211 e 216, as amostras foram coletadas soltas, sem orientação de topo e base. As descriçôes preservacionais que indicam topo e base nestas amostras no trabalho de Zaine (1991) foram, portanto, interpretativas, não comprovadas por dados ou observações de campo. No presente trabalho optou-se por uma descrição neutra (semi-relevo) quanto ao topo e à base, deixando a interpretação deste posicionamento para a parte de descrição dos objetos.

As amostras são agrupadas abaixo de acordo com o seu local de coleta e descritas e analisadas, separadamente, levando-se em conta o seu contexto geológico de seu ponto de coleta. Por fim, estes grupos de amostras também são analisados como um todo, dentro da Formação Raizama.

\subsubsection{Conjunto 1}

Localidade 2 de 02 de fevereiro de 1986 - Consiste de uma pedreira abandonada (explorada originalmente para brita) de aproximadamente $50 \times 100 \mathrm{~m}$, em planta, a $4 \mathrm{~km}$ a $\mathrm{S}$ do marco de Km 64 da rodovia BR-174 (Cuiabá- Porto Velho) na Serra do Padre Inácio, 60Km, pela estrada, a W de Cáceres, MT. Embora localizada em área identificada em mapas como a 
Formação Araras, a associação de quartzo arenitos, alguns conglomeráticos (com intraclastos de argilito e de dolomito) e dolarenitos, ambos com abundante estratificação cruzada, bem como a presença de termos pelíticos, marcados por gretas de contração, abre a possibilidade de que se trate de uma zona de contato transicional entre as Formações Araras e Raizama. Desta forma, os supostos icnofósseis e dubiofósseis deste local foram atribuídos à parte inferior da Formação Raizama por Zaine (1991) em sua tese. O acamamento nos termos areníticos é fino a espesso, com alguns níveis finos de arenitos muito finos. Camadas finas $(<10 \mathrm{~cm})$ de dolomito silicificados exibindo pseudomorfos de cristais de anidrita (em agregados com forma de "couve-flor") também ocorrem. Na parte superior da sucessão encontram -se não apenas termos pelíticos com gretas de contração, inclusive alguns em forma de " 8 ", mas também níveis de carbonato silicificado com pseudomorfos de anidrita.

As amostras pertencentes a este conjunto são GP/7E-210 e GP/7E- 213. A amostra GP/7E213 foi descrita erroneamente no texto por Zaine (1991, p.122) sob o número GP/7E- 214, mas corretamente na pranchas fotográficas (Zaine, 1991, estampa 13). A amostra GP/7E210 é aqui analisada pela primeira vez.

\subsubsection{Amostra GP/7E-210 (Amostra 4 de 2/2.2.86)}

\section{Descrição}

Arenito fino a muito fino (granulometria de 62 a $125 \mu \mathrm{m}$ ), carbonático de coloração rosa de diferentes tonalidades. Estruturalmente é possível distinguir clastos, camadas rompidas e uma laminação convoluta. No seu topo, ocorrem marcas onduladas com seus vales preenchidos por material mais fino (silte) também carbonático. Nesta superficie ocorrem traços lineares curvos a meandrantes (Fig. 6.3). 


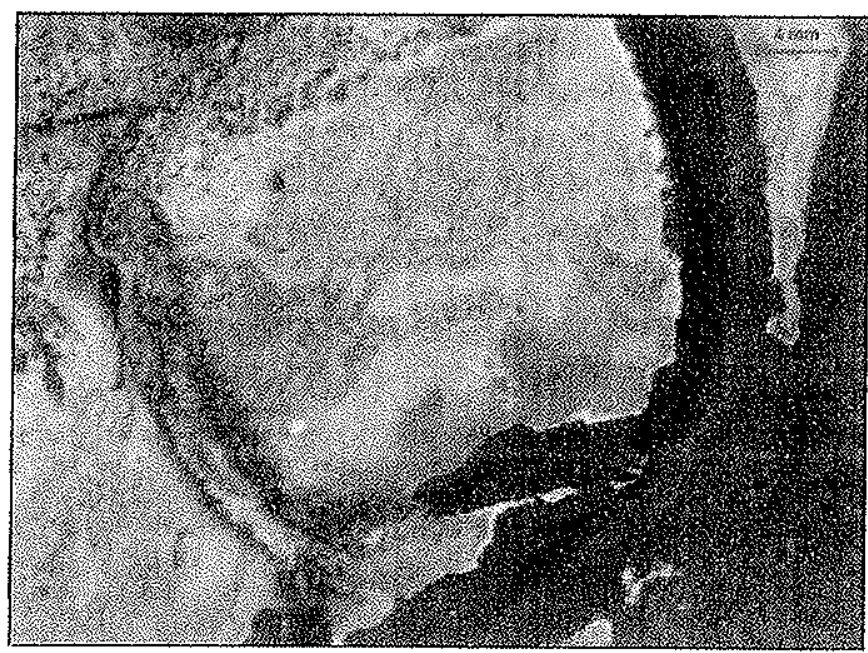

Figura 6.3 - Superfície da amostra GP/7E - 210, com os objetos similares a gretas de contração.

Os traços encontrados na camada superficial (pelito rosa claro e escuro) do topo desta amostra ocorrem em epirreleno convexo são curvos, recurvados ou meandrantes, parecendo intercruzar-se. O seu comprimento varia de 30 a $100 \mathrm{~mm}$, sua largura de 1 a $4 \mathrm{~mm}$, oscilando ao longo de um único traço e sua profundidade de 2 a $6 \mathrm{~mm}$. O seu preenchimento é de material distinto (mais grosso) da camada onde ocorrem. Em corte transversal eles apresentam contornos elípticos em alguns pontos e retangulares em outros.

\section{Discussão}

Os objetos analisados nesta amostra se enquadram nos seguintes critérios de origem abiogênica: critério (a) Semelhança com estrutura sedimentar ou diagenética; critério (b) Dimensões variáveis ou adelgadas; critério (c) tamanho e/ou forma não uniforme de múltiplas estruturas; e critério (d) padrão geométrico irregular, não se enquadrando em nenhum dos critérios de origem biogênica. Estes objetos são interpretados como gretas de contração ortogonais, aleatórias e completas de formas regulares com preenchimento em um único evento, segundo a classificação de Allen (1984). São classificados com um índice de biogenicidade 1, ou seja não biogênico ou pseudofóssil.

Esta amostra, obviamente abiogênica, foi facilmente interpretada como exemplo de gretas de contração. Aproveitando-se o fato dela pertencer ao conjunto de amostras da região 
estudada, sua análise aqui serviu de teste tanto para a metodologia proposta como de modelo de comparação para outras amostras.

\subsubsection{Amostra GP/7E-213 (Amostra 2 de 2.2.86)}

\section{Descrição}

Arenito fino a médio $(125-500 \mu \mathrm{m})$, apresentando eventuais placas de argila internamente. Na sua superfície superior, e próximo a ela, ocorre uma camada de granulometria mais fina que areia (silte ou argila). Associados aos restos desta camada ocorrem os objetos que são analisados abaixo (Fig. 6.4).

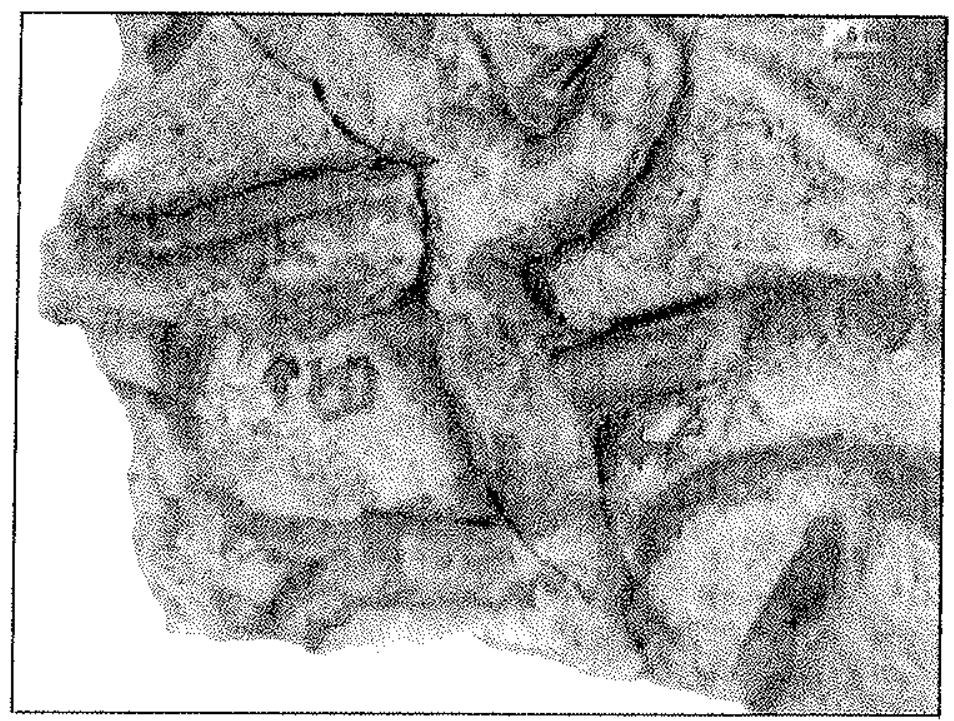

Figura 6.4 - Superficie onde ocorrem os objetos ( 1 e 2$)$ na amostra GP/7E-213.

Os objetos ocorrem em semi-relevo convexo e côncavo. São compostos, quando preenchidos, por areia muito fina. Podendo ser distinguidos dois tipos de objetos:

a) Objeto 1- Traços suavemente curvos, com comprimento entre 40 e $49 \mathrm{~mm}$, largura entre 3 e $11 \mathrm{~mm}$, altura entre 4 e $5 \mathrm{~mm}$ nos semi-relevos convexos preenchidos, e profundidade entre 1 a $2 \mathrm{~mm}$ nos semi-relevos côncavos não preenchidos. Em corte transversal são aproximadamente retangulares e apresentam um sulco raso na superficie superior. Estes objetos apresentam diferentes graus de corrugação, variando de corrugações discretas impressas nos exemplares em semi-relevo 
côncavo a fortemente corrugadas no objeto em semi-relevo convexo (ver Fig. 6.6). Também se afinam em direção as extremidades. (Fig. 6.4 - 1).

b) Objeto 2- Traços suavemente curvos, com comprimento variando de 8 a $28 \mathrm{~mm}$; largura, de 2 a $8 \mathrm{~mm}$; altura, de 1 a $3 \mathrm{~mm}$ nos semi-relevos convexos preenchidos $\mathrm{e}$ profundidade entre de 1 e $3 \mathrm{~mm}$ nos semi-relevos côncavos não preenchidos. Em corte transversal, assim como no objeto 1, aparecem aproximadamente retangulares. Os objetos se afinam em direção às suas extremidades e, em pelo menos um exemplar, ocorre uma bifurcação onde as partes bifurcadas apresentam metade da largura inicial do objeto. (Fig. 6.4-2).

A amostra original depositada nas coleções do IGc-USP próvem do meio de uma placa (Fig. 6.5) ilustrada por Zaine (1991, estampa 13) onde pode-se identificar um claro padrão de gretas de contração ortogonais, aleatórias e completas, de acordo com a classificação de Allen (1984).

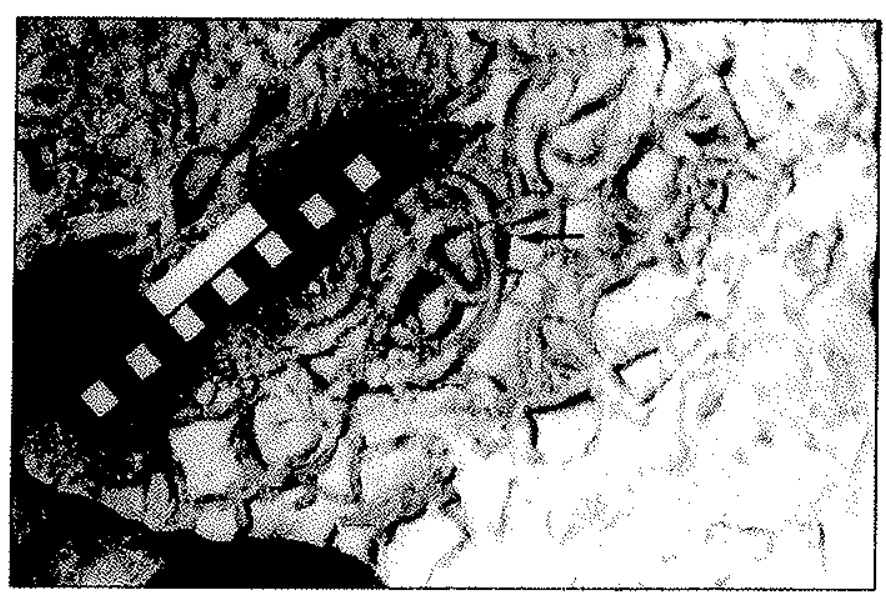

Figura 6.5 - Amostra original de onde foi retirada a amostra GP/7E-213 (na área indicada na seta) (Extraída de Zaine, 1991).

\section{Discussão}

Estes objetos foram classificados por Zaine (1991) como Dubiofóssil 3 (objeto 1) e como Planolites sp (objeto 2).

O objeto 1 se enquadra nos critérios de origem não biogênica: critério (a) assemelhando-se a estrutura sedimentar Rhysonetron, descrita por Hofmann (1971); critério (b) dimensões variáveis e adelgaçamento; e critério (e) orientação preferencial estrita -- todos os objetos 
corrugados estão alinhados aproximadamente na mesma direção. Mas o objeto 1 também satisfaz pelo menos um dos critérios de origem biogênica, critério (b) sendo razoavelmente regulares, complexos e repetitivos. Suas bordas corrugadas assemelham-se as icnogênero Arthrophycus. Devido à semelhança desses objetos com estrutura sedimentar e, também com icnito, foi realizada uma comparação entre estes icnitos semelhantes, do icnogênero Arthrophycus, estruturas sedimentares descritas originalmente como Rhysonetron e os objetos 1, como pode ser visto na Fig. 6.6.

\begin{tabular}{|c|c|c|c|c|c|}
\hline & $\begin{array}{l}\text { Arthrophycus } \\
\text { Fm. Furnas } \\
\text { (Fernandes et } \\
\text { al., 2000) }\end{array}$ & $\begin{array}{l}\text { Arthrophycus Fm. } \\
\text { Vila Maria } \\
\text { (Coleções IGc } \\
\text { GP/7E } 299 \text { e } 300 \text { ) }\end{array}$ & $\begin{array}{l}\text { Arthrophycus FM. } \\
\text { Nhamundá } \\
\text { (Nogueira, no } \\
\text { prelo) }\end{array}$ & $\begin{array}{l}\text { Objeto da Fm } \\
\text { Raizama (GP/7E } \\
213 \text {, presente } \\
\text { trabalho) } \\
\end{array}$ & $\begin{array}{l}\text { Rhysonetros lahtii } \\
\text { (Hofmann, 1967) } \\
2,50 \mathrm{Ga}\end{array}$ \\
\hline Comprimento & $14,5 \mathrm{~cm}$ & $17,5 \mathrm{~cm}$ (parcial) & $\operatorname{lm}$ & $4,5 \mathrm{~cm}$ & Até $17,0 \mathrm{~cm}$ \\
\hline Diâmetro & 5,2 a $7,7 \mathrm{~cm}$ & 1,3 a $2,0 \mathrm{~cm}$ & 2 a $6 \mathrm{~cm}$ & $\begin{array}{l}1,2 \text { a } 0,7 \mathrm{~cm} . \\
\text { Espesso, atenuado } \\
\text { nas extremidades. }\end{array}$ & $0,7 \mathrm{~cm}$ \\
\hline $\begin{array}{l}\text { Seção } \\
\text { transversal }\end{array}$ & $\begin{array}{l}\text { Circular a } \\
\text { elípitica }\end{array}$ & $\begin{array}{l}\text { Elíptica, } \\
\text { subcircular, vários } \\
\text { de baixo relevo }\end{array}$ & $\begin{array}{l}\text { Elípticas a } \\
\text { subquadráticas }\end{array}$ & $\begin{array}{l}\text { Elíptica, } \\
\text { sub-retangular }\end{array}$ & Elíptica a circular \\
\hline Ramificações & Dicôtoma & $\begin{array}{l}\text { Um exemplo } \\
\text { dicôtomo }\end{array}$ & $\begin{array}{l}\text { Dicotôma a } \\
\text { quadricôtoma }\end{array}$ & Ausente & Não \\
\hline $\begin{array}{l}\text { Largura das } \\
\text { anulações }\end{array}$ & 0,8 a $2,1 \mathrm{~cm}$ & 0,4 a $0,5 \mathrm{~cm}$ & $3,3 \mathrm{~mm}$ & 2 a $3 \mathrm{~mm}$ & 1 a $3 \mathrm{~mm}$ \\
\hline $\begin{array}{l}\text { Forma das } \\
\text { anelações }\end{array}$ & $\begin{array}{l}\text { Não } \\
\text { visualizável nas } \\
\text { fotos }\end{array}$ & Arredondadas & Arredondadas & $\begin{array}{l}\text { Arredondado } \\
\text { simétrico / } \\
\text { assimétrico } \\
\end{array}$ & $\begin{array}{l}\text { Sulcos inclinados, } \\
\text { regulares }\end{array}$ \\
\hline $\begin{array}{l}\text { Inter } \\
\text { cruzamentos }\end{array}$ & Intenso & Intenso & Intenso & Discutível & Discutível \\
\hline Orientação & $\begin{array}{l}\text { Predominante } \\
\text { horizontal }\end{array}$ & $\begin{array}{l}\text { Concordante } \\
\text { horizontal }\end{array}$ & $\begin{array}{l}\text { Concordante } \\
\text { subconcordante }\end{array}$ & $\begin{array}{l}\text { Concordante } \\
\text { horizontal }\end{array}$ & $\begin{array}{l}\text { Paralelos ao } \\
\text { acamamento }\end{array}$ \\
\hline Densidade & $\begin{array}{l}\text { Alta em mais } \\
\text { de um nivel }\end{array}$ & $\begin{array}{l}\text { Alta em mais de } \\
\text { um nível }\end{array}$ & Alta & Baixa & Baixa a moderada \\
\hline $\begin{array}{l}\text { Estrutura } \\
\text { longitudinal }\end{array}$ & $\begin{array}{l}\text { Tênue } \\
\text { depressão/sulco } \\
\text { longitudinal }\end{array}$ & Tênue & $\begin{array}{l}\text { Bilobada às vezes } \\
\text { com sulco } \\
\text { mediano }\end{array}$ & $?$ & Crista mediana \\
\hline Ambiente & Agitado & ---- & Agitado & $\begin{array}{l}\text { Associado a } \\
\text { gretas }\end{array}$ & $\begin{array}{l}\text { Associado a } \\
\text { marcas onduladas, } \\
\text { estr. cruzada e } \\
\text { gretas de } \\
\text { contração }\end{array}$ \\
\hline Idade & Devoniano & Eossiluriana & Siluriano & $\begin{array}{l}\text { Vendiano / } \\
\text { Cambriano }\end{array}$ & Paleoproterozóico \\
\hline Relevo & $\begin{array}{l}\text { Epirrelevo } \\
\text { côncavo }\end{array}$ & $\begin{array}{l}\text { Hiporrelevo } \\
\text { convexo }\end{array}$ & $\begin{array}{l}\text { Hiporrelevo } \\
\text { convexo }\end{array}$ & $\begin{array}{l}\text { Epirrelevo } \\
\text { convexo, e } \\
\text { epirrelevo } \\
\text { côncavo (?) }\end{array}$ & $\begin{array}{l}\text { Epirrelevo } \\
\text { convexo }\end{array}$ \\
\hline
\end{tabular}

Figura 6.6 - Quadro comparativo entre a amostra GP/7E-213 e icnofósseis do gênero Arthrophycus e estruturas sedimentares do tipo Rhysonetron. 
Com base nesta análise comparativa e nos critérios relativos às origens biogênica $\mathrm{e}$ abiogênica, estes objetos foram classificados com índice de biogenicidade 1 , ou seja abiogênico ou pseudofóssil, sendo atribuídos a estruturas sedimentares do tipo Rhysonetron (Fig. 6.7). As estruturas Rhysonetron foram inicialmente descritas por Hofmann (1967) em rochas com mais de dois bilhões de anos como estruturas biogênicas com base em sua semelhança a "vermes segmentados" e classificadas em duas icnoespécies, $R$. lahtii e $R$. byei. Posteriormente, Hofmann (1971) reconheceu que, apesar do aspecto sugestivo, Rhysonetron era produzido por processos inorgânicos sedimentares e diagenéticos. Segundo ele, um conjunto de gretas preenchidas e o sedimento argiloso encaixante foi submetido a compactação dinâmica (não simplesmente litoestática) com comportamento diferenciado do preenchimento arenoso e sedimento encaixante pelítico. Neste processo, teria ocorrido o encurtamento das gretas lineares acompanhado da mobilização e remoção de quase toda a camada pelítica em torno das gretas preenchidas, imprimindo nestas o padrão peculiar de corrugações (Fig. 6.8).

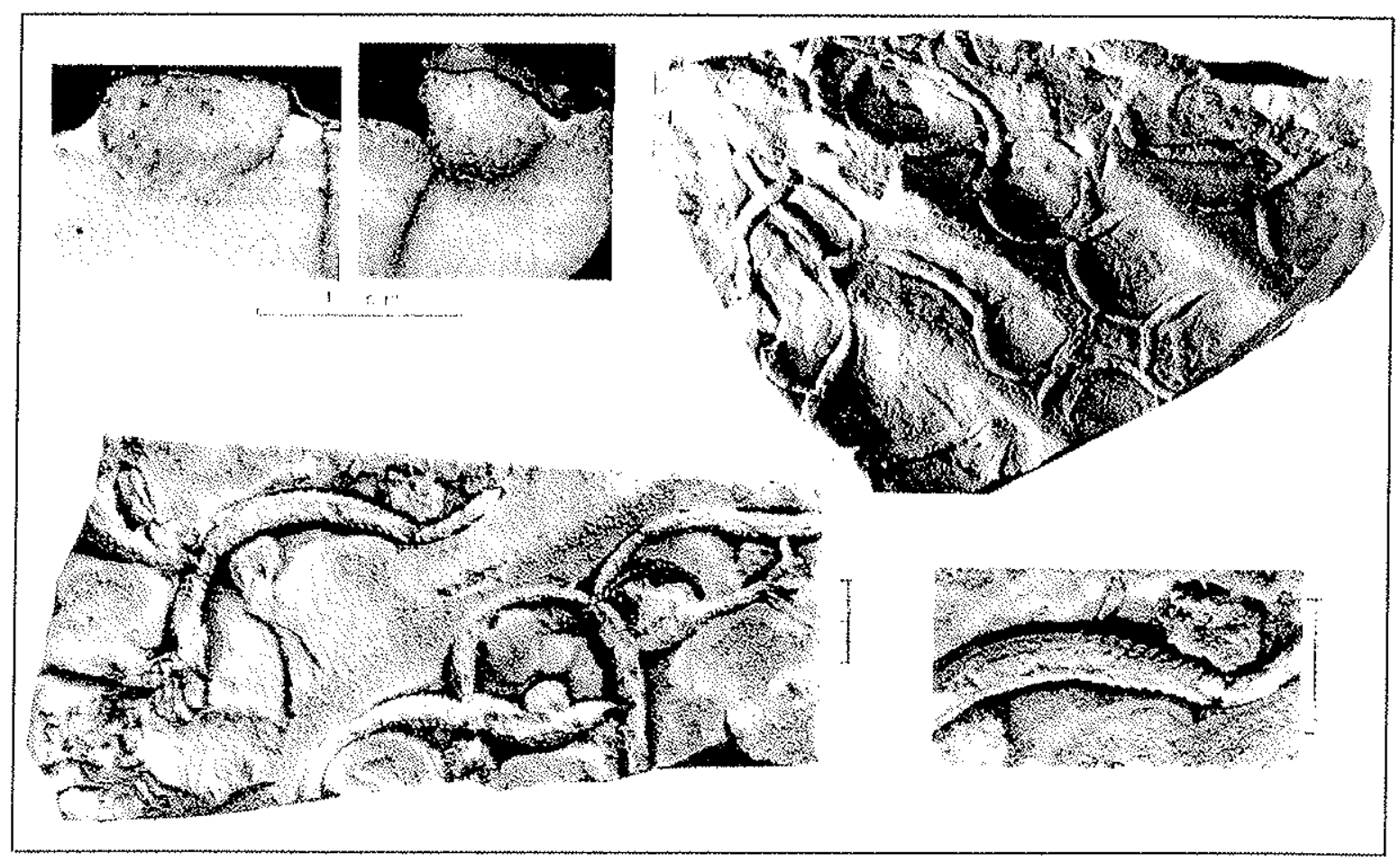

Figura 6.7 - Estruturas sedimentares do tipo Rhysonetron (Modificada de Häntzschel, 1975). 


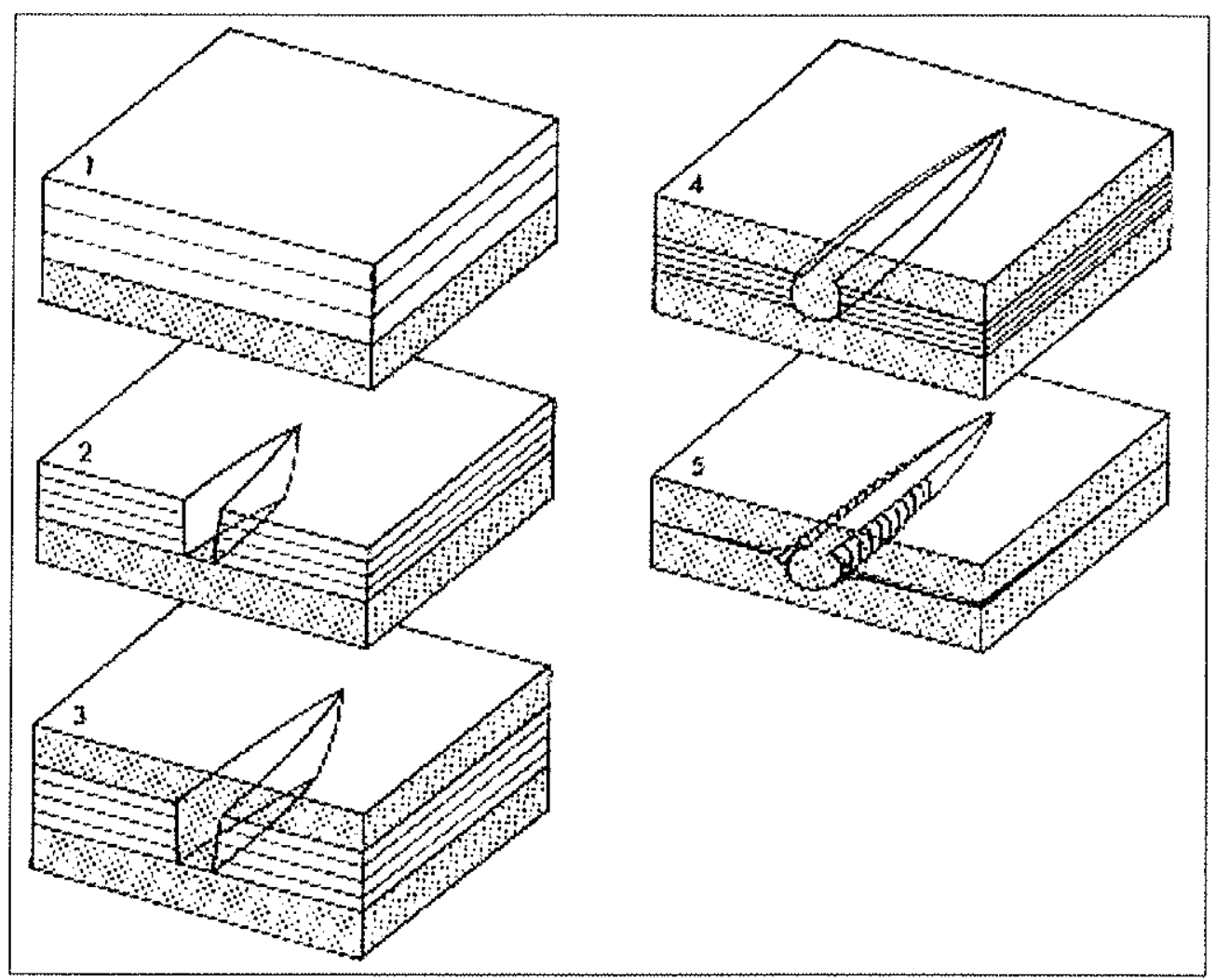

Figura 6.8 - Diagrama esquemático com os estágios da formação de Rhysonetron: 1) acumulação de lama; 2) desenvolvimento da greta; 3) preenchimento e recobrimento da lama por areia; 4) compactação da lama e compressão da areia gerando formas fusiformes (estágio do Manchuriophycus); e, 5) posterior redução do volume de lama e compressão das formas fusiformes (estágio do Rhysonetron). (Modificada de Hofmann, 1971)

O objeto 2 também se enquadra nos seguintes critérios de origem abiogênica: critério (a) semelhança com estrutura sedimentar ou diagenética; critério (b) dimensões variáveis ou adelgaçadas; e critério (c) tamanho e/ou forma não uniforme de múltiplas estruturas. Quanto aos critérios de origem biogênica, este objeto poderia satisfazer o critério (b) forma geométrica regular, complexa e repetitiva. Mas como já discutido anteriormente no capítulo 3, estas características também podem ocorrer em algumas estruturas não biogênicas, como gretas de contração, por exemplo. Sendo assim, estes objetos são classificados com índice de biogenicidade 1, ou seja, abiogênicos ou pseudofósseis. São atribuídos ao processo de gretamento que ocorre associado a eles e descritos como gretas de contração. 


\subsubsection{Conjunto 2}

Localidade 2 de 03 de fevereiro de 1986 -- Compreende um longo trecho de cortes de estrada altos ao longo da rodovia BR-70 (Cuiabá-Cáceres) entre os quilômetros 692,7 e 694,2 , a $35 \mathrm{Km}$ a SE de Cáceres. Constitui uma das melhores exposições conhecidas da Formação Raizama. A sucessão é inteiramente siliciclástica, constituída de arenitos e arenitos conglomeráticos em camadas finas a médias, estratificação cruzada e marcas onduladas. Em certos níveis, são comuns vazios nos arenitos, possivelmente representando clastos carbonáticos (ou argilosos) lixiviados. Para o topo da seção examinada, notaram-se mais freqüência de termos finos e gretas de contração.

Este conjunto compreende as amostras GP/7E-211 e GP/7E-215. Estas amostras ocorrem em um afloramento com diversos niveis com gretas, onde as camadas argilosas são raras e as retas estão associadas a arenito fino/muito fino, finamente laminado.

\subsubsection{Amostra GP/7G-211 (Amostra 2 de 3.2.86)}

\section{Descrição}

Arenito fino a muito fino $(62-125 \mu \mathrm{m})$ de coloração amarela e rósea, friável, com marcas onduladas simétricas, suavemente sinuosas, às vezes bifurcadas, com cristas de $5 \mathrm{~mm}$ de altura e de comprimento de onda entre 35 e $50 \mathrm{~m}$. Esta amostra é ligeiramente friável e se encontra visivelmente deteriorada desde que foi descrita e ilustrada por Zaine em 1991 (Fig $6.9)$

Os objetos ocorrem em epirelevo ora côncavo ora convexo de acordo com a presença ou não de preenchimento. Compreende traços horizontais, lisos, irregularmente meandrantes que se estendem grosseiramente paralelos às cristas, sendo praticamente confinados aos sulcos. Há, no entanto, algumas evidências, embora bastante tênues, de que alguns talvez tenham cruzado as cristas. 

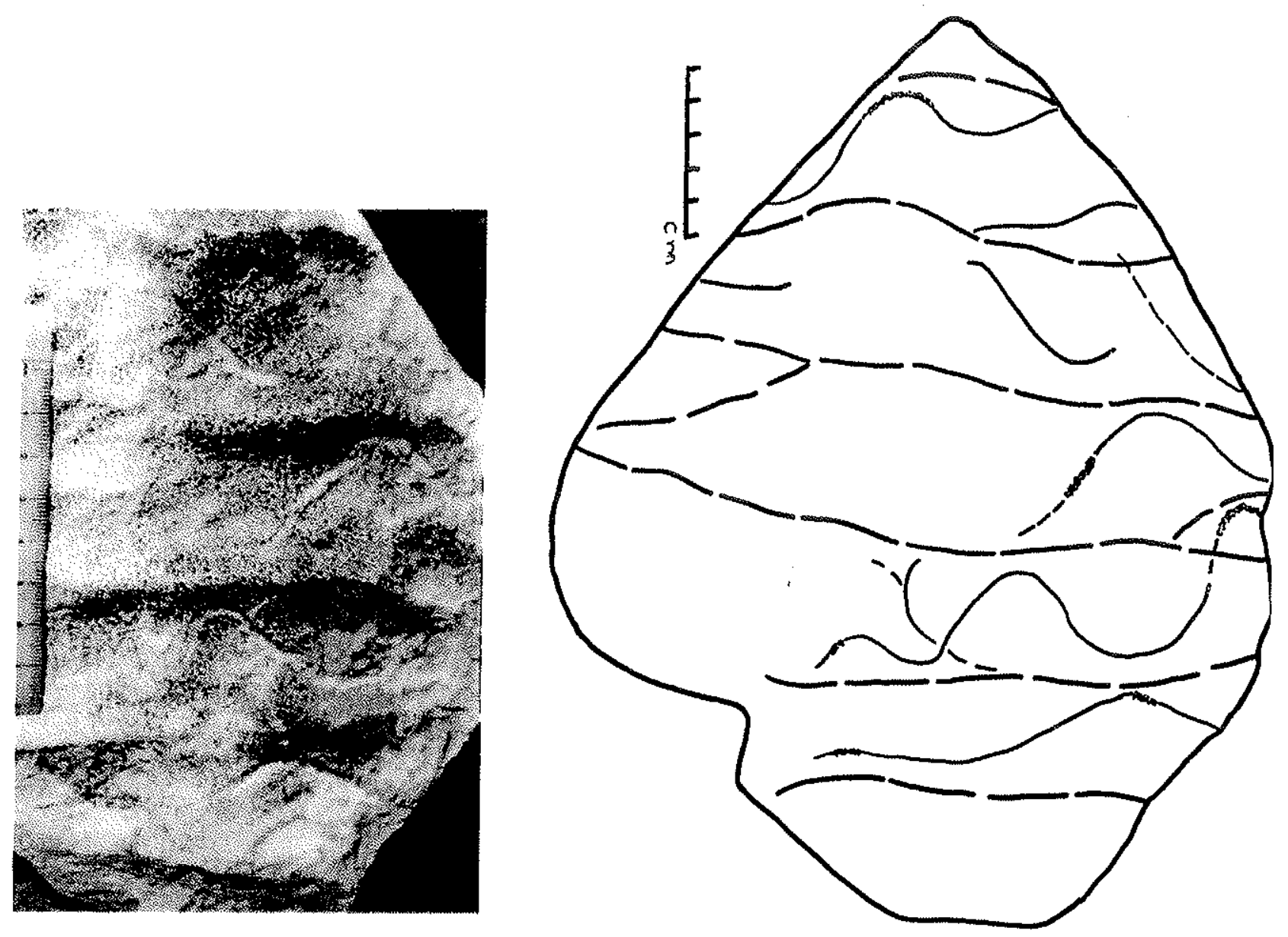

Fig 6.9 -Objetos na superfície ondulada da amostra GP/7E - 211 (a esquerda) e desenho esquemático da amostra (a direita).

Devido ao grau de deterioração da amostra, não foi possível verificar com precisão as medidas destes objetos, admitindo as medidas originais como representantes das suas dimensões reais. Assim, segundo Zaine (1991), os sete espécimes variam em comprimento de 22 a $93 \mathrm{~mm}$; em largura de 2 a $3 \mathrm{~mm}$; em amplitude dos meandros de 6 a $20 \mathrm{~mm}$; e em comprimento de onda dos meandros de 35 a $40 \mathrm{~mm}$. O seu relevo, tanto côncavo quanto convexo, não ultrapassa 1 ou $2 \mathrm{~mm}$.

\section{Discussão}

Zaine (1991) admitiu uma origem biogênica deste objeto com base na semelhança deste com a definição de Crimes (1987) para Cochlichnus -- escavação sinuosa e simples que aparece no Vendiano e tem registro por todo o Fanerozóico. Segundo ela, estes objetos diferem de C. kochi (Ludwig) ilustrado porem Häntzschel (1975) e de Cochlichnus em Aceñolaza (1978) pela falta de regularidade de seus meandros e, diferindo também de 
C. lagartensis (Muniz, 1980) por apresentar interrupções dos meandros a cada três concavidades.

Vários critérios de origem abiogênica se aplicam neste caso: critério (a) semelhança com estrutura sedimentar inorgânica - por exemplo, a gretas de sinerese, longas e sinuosas ou em forma de 8 (ver Plummer \& Gostin, 1981) (Fig. 6.10); critério (b) padrão geométrico irregular -- o padrão dos meandros deste objeto é bastante irregular. $\mathrm{E}$ quanto aos critérios de origem biogênica, eles apresentam o critério (a) tamanho e/ou continuidade de uma estrutura individualmente -- mantendo suas dimensões e sua continuidade ao longo de sua extensão; e similaridade com o icnogênero Cochlichnus. Com base nos critérios descritos acima, e no estado atual de deterioração da amostra, classificamos os objetos com índice de biogenicidade 4, ou seja, dubiofóssil. São parecidos tanto com: gretas irregulares e em " 8 ", abiogênicas; como com Cochlichnus icnosp., biogênica.

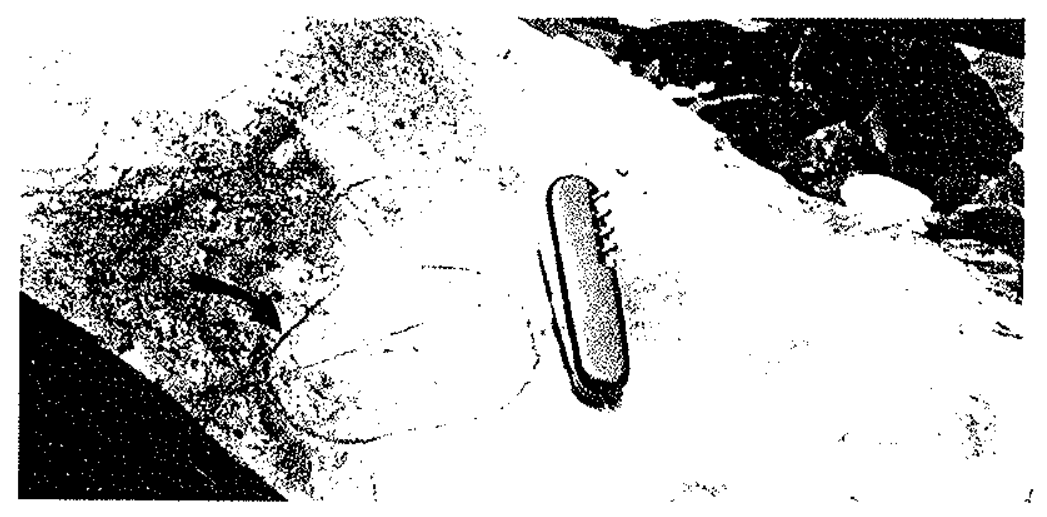

Fig. 6.10 - Gretas em forma de 8 na Formação Águas Claras, Arqueano do Pará (Extraída de Nogueira, 1995).

\subsubsection{Amostra GP/7E - 215 (Amostra 1 de 3.2.86)}

\section{Descrição}

Arenito de coloração rosa, apresentando duas porções distintas: um arenito fino a médio (125 -500 $\mu \mathrm{m})$, apresentando granocrescência em direção ao interior da amostra, com grãos arredondados a subangulosos; e a outra, de arenito muito fino (62-125 $\mu \mathrm{m})$, com grãos subangulosos a subarredondados. Não apresenta laminação evidente.O contato entre estas 
porções é delimitado, quase sempre, por uma fina lamina $(\leq 1 \mathrm{~mm})$ de arenito muito fino $(62-88 \mu \mathrm{m})$ de coloração amarela, suavemente ondulado. Perpendicularmente a estas camadas ocorrem algumas fraturas.

Em lamina delgada, a porção mais fina é composta por quartzo $(\cong 70 \%)$, feldspato $(\cong 15 \%) \mathrm{e}$ fragmentos de rocha $(\cong 15 \%)$, geralmente com contato tangencial dos grãos. Já a porção mais grossa, tem uma composição mais quartzosa, com quartzo $(\cong 78 \%)$, fragmentos de rocha $(\cong 15 \%)$ e feldspato $(\cong 7 \%)$, com contato côncavo-convexo dos grãos.

O objeto ocorre em semi-relevo convexo, na porção mais fina da rocha, com $25 \mathrm{~mm}$ de comprimento, 7 a $9 \mathrm{~mm}$ de largura e 1 a $2 \mathrm{~mm}$ de altura. A composição granulométrica do objeto é similar a da porção mais grossa da amostra. Seu contorno é semi-elípitico $60 \%$ completo. Em corte transversal demonstra uma continuidade parcial com esta camada (Fig. $6.11)$.
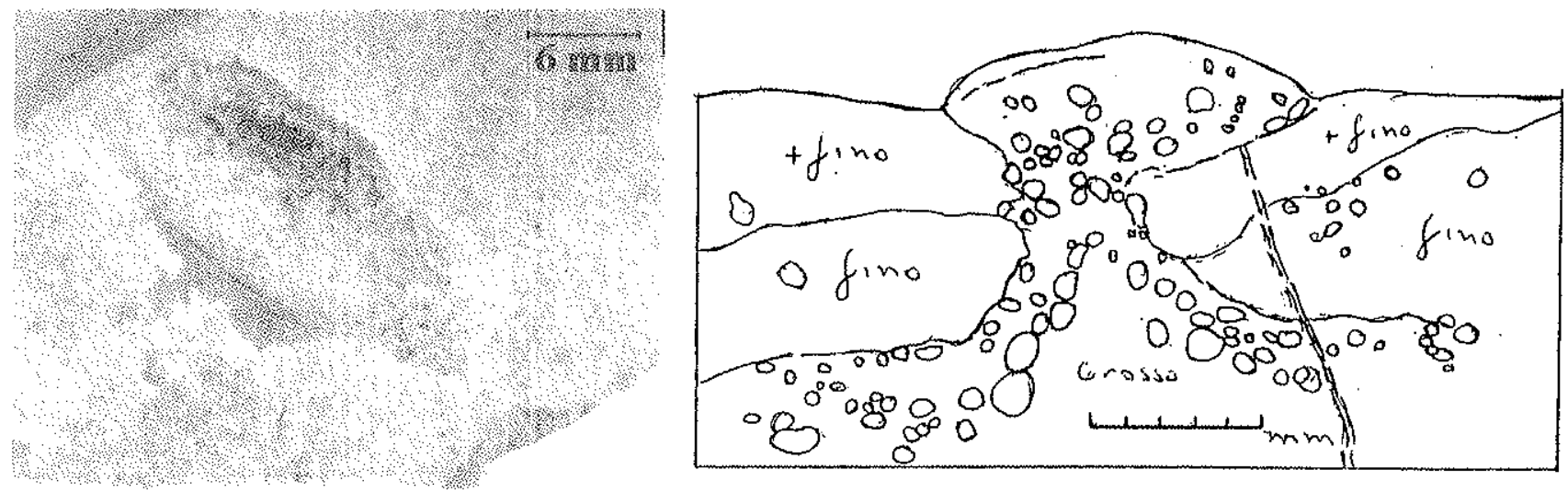

Fig 6.11 - Objeto na superfície da amostra GP/7E -215 (a esquerda) e desenho esquemático do objeto visto em corte tranversal (a direita).

Discussão

Zaine (1991) classificou este objeto como dubiofóssil, semelhante ao icnogênero Rusophycus - um icnito de descanso atribuído a trilobitas. Este objeto se enquadra, quando observado em corte transversal, parcialmente no critério (d) de origem abiogênica padrão geométrico irregular-como pode ser observado na Fig. 6.11, e parcialmente no critério (a) 
de origem biogênica, tamanho uniforme de uma estrutura individual - por apresentar, de modo geral, dimensões razoavelmente uniformes. A morfologia deste objeto em seção transversal é bastante sugestiva (Fig. 6.11) assemelhando-se a alguns icnogêneros (por exemplo, Harlaniella), mas a relação entre o objeto e a camada mais grossa na porção incompleta da semi-elípse não é favorável a uma origem biogênica. Com base nestes critérios e, principalmente, nas feições em seção transversal, classificamos o objeto com índice de biogenicidade 3, ou seja, possivelmente abiogênico. Assemelha-se a certas estruturas de sobrecarga, por exemplo, "pillow structures", formadas pela interação dinâmica entre sedimentos de densidades, viscosidade e granulometrias diferentes (Allen, 1984). Se for comprovada esta hipótese, concluir-se-á que o objeto ocorre na sola da camada. Estruturas desse tipo, entretanto, não costumam, ocorrer isoladamente mas sim em arranjos densos. E se fosse biogênico, como poderia ter se formado? Admitindo a posição do objeto na base da camada, o contorno elíptico $60-70 \%$ completo evidente em corte e seu preenchimento por sedimento mais grosso que o sedimento encaixante poderiam ser explicados, eventualmente, pelo preenchimento e posterior compactação de um tubo feito por um organismo se deslocando ou ingerindo sedimento ora na porção mais fina (inferior) ora na porção mais grossa (superior) da amostra. Enquanto não houver mais exemplares, esta possibilidade continuará hipotética.

\subsubsection{Conjunto 3}

Localidade 3 de 01 de fevereiro de 1986 -.. Localiza-se à margem da rodovia federal BR070 (Cuiabá- Cáceres), no quilometro 710,2 , aproximadamente $20 \mathrm{Km}$ a SE de Cáceres (MT) dentro do conjunto de espigões múltiplos que compreendem a Serra das Araras. Compreende uma pequena escavação aberta como área de empréstimo para a construção da rodovia. A Formação Raizama neste local consiste principalmente de arenitos em camadas finas com algumas intercalações pelíticas finas. Destacam se aqui diversas estruturas sedimentares primárias indicativas de ambiente muito raso, ou até exposto, como,por exemplo, marcas onduladas de cristas aplainadas, marcas onduladas de interferência e estratificação cruzada. Possiveis gretas de contração, intraclastos de argila e questionáveis 
moldes de evaporitos também foram notados neste afloramento. Foi atribuído à parte inferior da Formação Raizama por Zaine (1991).

Este conjunto é composto das amostras GP/7E-212, GP/7E-214 e GP/7E-216 descritas por Zaine (1991) e das amostras GP/7E-218 a 220, coletadas por ela, mas descritas pela primeira vez no presente trabalho. Com estas amostras também ocorreram alguns equivocos na sua numeração na tese de doutoramento de Zaine (op. cit.), com a numeração errada da amostra GP/7E-212 como 211 e 213 (p. 117e 118) e da amostra GP/7E-214 como 212 (p. 118), no texto, mas com a numeração correta nas estampas fotográficas (estampa 12).

\subsubsection{Amostra GP/7E-212 (Amostra 4 de 1.2.86)}

\section{Descrição}

Arenito fino e médio $(125-177 \mu \mathrm{m}$ e $350-500 \mu \mathrm{m})$, de coloração amarela, sustentado pelos grãos, com grãos bem arredondados a subarredondados. Estruturas evidentes na amostra incluem estratificação cruzada, aparentemente acanalada, superfície suavemente ondulada e fraturas.

Os objetos presentes nesta amostra são semi-relevos convexos de dois tipos diferentes:

a) Objeto 1- três traços retilíneos em semi-relevo convexo, de comprimento entre $30 \mathrm{e}$ $80 \mathrm{~mm}$, largura inferior a $2 \mathrm{~mm}$ e altura inferior a $1 \mathrm{~mm}$, que foram interpretados inicialmente como Planolites sp. 1 por Zaine (1991). Estes objetos, embora interpretados como biogênicos por Zaine, representam claramente fraturas preenchidas inclusive com movimentação (bloco alto e baixo), cortando objeto do tipo 2 e no prolongamento de superficie de quebra da amostra (Fig. 6.12). Desta forma, seu índice de biogenicidade é 1 , ou seja, abiogênico ou pseudofóssil.

b) Objeto 2- sete marcas de formato losangular em semi-relevo convexo (Fig. 6.12, números 1 a 5,9 e 10) e três marcas losangulares em suaves semi-relevo côncavo (Fig. 6.12, números 6 a 8). As marcas em semi-relevo convexo parecem, inicialmente, cravadas na rocha mas em corte transversal é possivel ver que eles encontram-se exclusivamente na camada superficial. Os exemplares 1 e 3 (Fig. 
6.12) consistem de mais de um elemento ( 3 e 2 elementos respectivamente). Embora tenham sido descritos inicialmente como similares a Lockeia (Zaine, 1991), um icnito de descanso de bivalves, nenhum exemplar simula fielmente as valvas características dessa classe de moluscos.
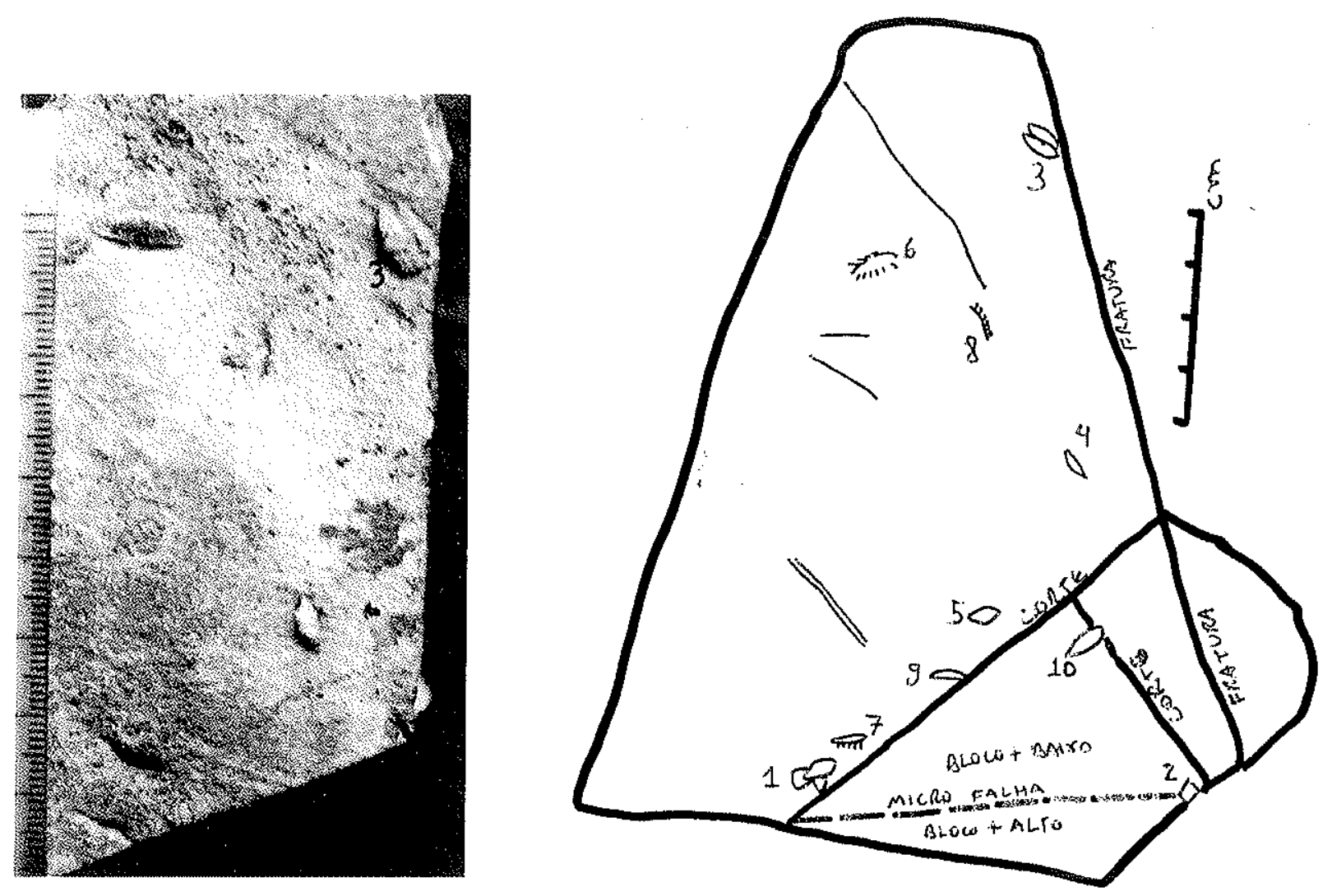

Figura 6.12 - Detalhe de parte da amostra GP/7E-212 (à esquerda) e desenho esquemático da superfície onde ocorrem os objetos na amostra GP/7E-212.

\section{Discussão}

Os critérios de origem biogênica em que os objetos se enquadram são: critério (a), tamanho e/ou continuidade de uma estrutura individual; critério (b) forma geométrica regular, complexa e repetitiva - embora em alguns exemplares ocorre mais de um elemento, a forma dos objetos de um elemento é razoavelmente regular e repetitiva. $\mathrm{E}$ os critérios de origem abiogênica destes objetos são: critério (b) dimensões variáveis ou adelgadas -- as dimensões de alguns exemplares, principalmente os com mais de um elemento, são 
razoavelmente variáveis; critério (c) tamanho e/ou forma não uniforme de múltiplas estruturas - embora apresentando feições geométricas similares, o tamanho e a forma destes objetos são razoavelmente variáveis na maioria das formas e bastante diferenciados nas formas com mais de um elemento; e, parcialmente em critério $(f)$, pois ainda que não representem substituição mineral óbvia, lembram estruturas de minerais salinos, especialmente cristais de gipsita. Estes critérios somados ao contexto geológico onde foram coletados com indícios de evaporitos no local, nos permitem coloca-los com índice de biogenicidade 2 , ou seja, provavelmente de origem abiogênica, sendo atribuídos a pseudomorfos de cristais salinos, como por exemplo gipsita. As formas com mais de um elemento poderiam representar estruturas do tipo "rosa do deserto". Eles teriam sido gerados na superfície de uma camada exposta, sendo posteriormente dissolvidos e seus espaços preenchidos pelos mesmos sedimentos que recobriram esta amostra. Esta interpretação implica em sua formação na base da camada depositada, sendo preservados em hiporrelevo convexo. Esta interpretação de topo e base é corroborada pelo modo de preenchimento das fraturas existentes (objeto 1).

\subsubsection{Amostra GP/7E-214 (Amostra 6 de 1.2.86)}

\section{Descrição}

Arenito muito fino a médio $(88-350 \mu \mathrm{m})$, de coloração amarela, com grãos subarredondados a angulosos. Apresenta laminação aparentemente planar mas de difícil visualização, mas possivelmente cruzada de baixo ângulo, sugerida por um nível de seixos placóides de argila. Pequenas fraturas e irregularidades também são comuns, devido, aparentemente, à quebra da irregular da amostra.

A análise de lâmina delgada revelou a presença, além do quartzo (85\% a 90\%), de fragmentos de rocha $(10 \%$ a $15 \%)$ e algum feldspato $(<1 \%)$. Ocorre interpenetração dos grãos, com contatos côncavo-convexos e suturados, e intercrescimento dos grãos de quartzo. Uma laminação fina é evidente em lâmina pela alternância de materiais mais finos e mais grossos. 
O objeto ocorre em semi-relevo convexo, medindo $42 \mathrm{~mm}$ de comprimento e 5 e $9 \mathrm{~mm}$ de largura. É preenchido pelo mesmo tipo de sedimento que o circunda (Fig. 6.13). Lateral e paralelamente ao objeto ocorre uma estrutura similar mas não tão bem demarcada. Em corte transversal não é possível visualizar nenhuma estrutura interna ou extensão do contorno externo para dentro do sedimento. Em ao menos um destes cortes, uma fina lamina de coloração clara (uma fratura ou plano sedimentar?) parece separar o objeto do resto da amostra.

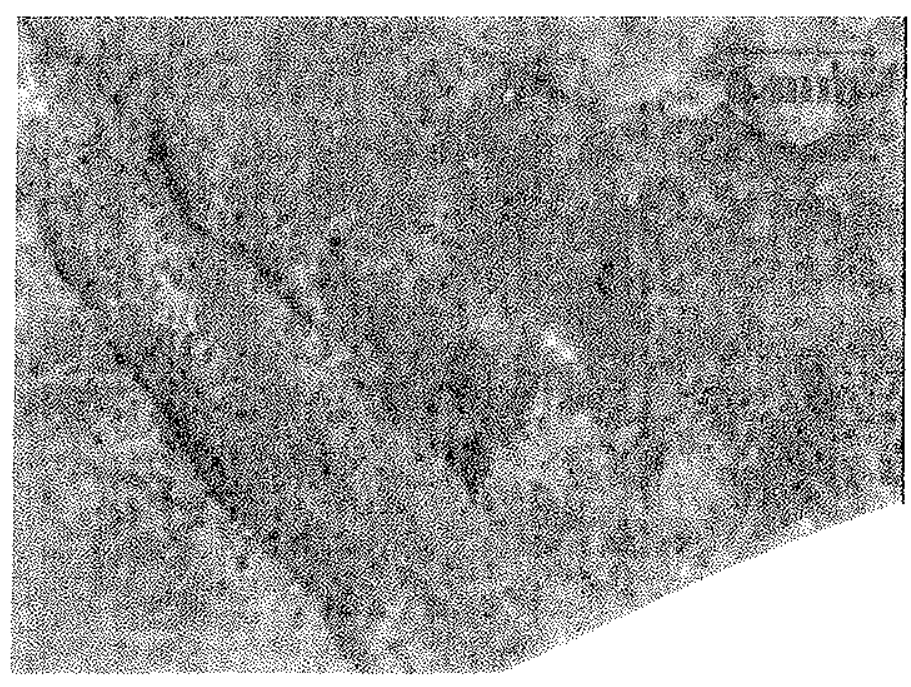

Figura $6.13-$ Objeto na superfície da amostra GP/7E 214.

\section{Discussão}

Zaine (1991) classificou este objeto como um icnofóssil pertencente ao icnogênero Palaeophycus. No entanto, não foi possível enquadra-lo em nenhum dos critérios de origem biogênica. Por outro lado, o objeto apresenta evidências de origem abiogênica, pelo critério (b) dimensठ̃es variáveis ou adelgadas. Com base na falta de critérios biogênicos plausiveis e na ocorrência de fraturas e de irregularidades superficiais algo similares em outras partes da amostra, este objeto é classificados com índice de biogenicidade 1, ou seja, abiogênico ou pseudofóssil, possivelmente refletindo a quebra irregular da rocha. 


\subsubsection{Amostra GP/7E-216 (Amostra 1 de 1.2.86)}

\section{Descrição}

Arenito fino a médio $(125-350 \mu \mathrm{m})$ de coloração amarela, grão subanguloso a subarredondado. As estruturas presentes são estratificação cruzada, com laminação gerada pela alternância granulométrica de areias finas e médias, e uma possível marca ondulada suave, num canto da amostra.

O objeto ocorre em epirrelevo côncavo, cujo fundo, relativamente plano, tem a forma de uma semi-elipse, bem demarcada, medindo $20 \mathrm{~mm}$ de eixo maior e $10 \mathrm{~mm}$ de eixo menor. Centralizadas mais ou menos simetricamente no eixo maior desta figura ocorrem quatro depressões bastante semelhantes em tamanho (de 3 a $5 \mathrm{~mm}$ em dimensão maior por 2 de largura) e forma grosseiramente losangular (Fig. 6.14). Durante a análise original desta amostra, um geólogo já falecido, consultado por M.F. Zaine, teve a infeliz idéia de realçar em grafite (lápis) o contorno e as depressões (inclusive uma quinta depressão, minúscula, localizada no centro do conjunto dessas depressões maiores) desta estrutura. Dessa forma, estas feições se tornaram as mais conspícuas na amostra, embora existam diversas outras depressões parecidas nesta mesma superfície, inclusive pelo menos uma outra elíptica de fundo plano e várias depressões irregulares menores dentro do próprio contorno do objeto

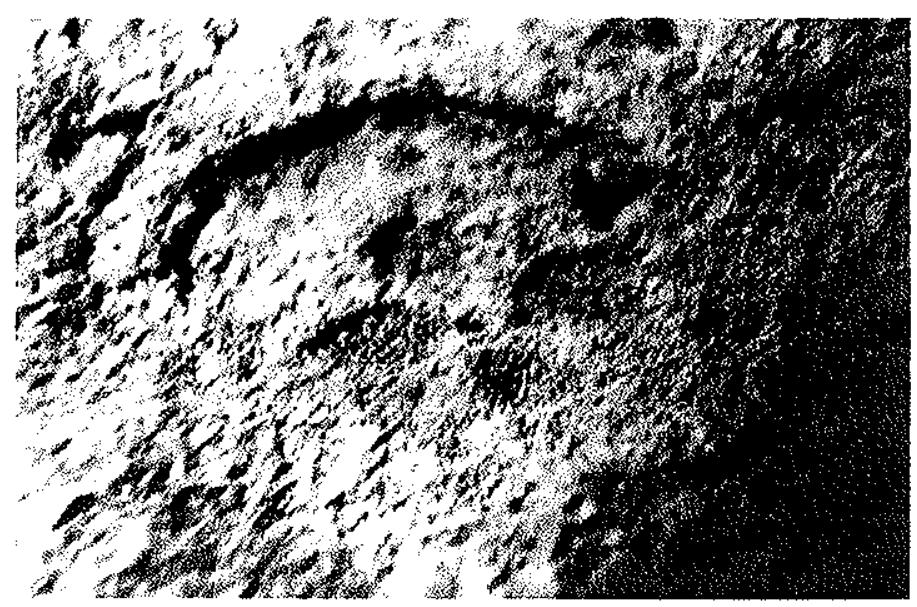

Figura 6.14 - Objeto salientado por contorno a lápis na amostra GP/7E - 216 . 


\section{Discussão}

Zaine (1991) chamou atenção para a semelhança do formato e da organização tetrâmera deste objeto, salientado pelo contorno a lápis, com certos medusóides da Classe Scyphozoa (cnidários) que possuem quatro bolsões gástricos bem demarcados. Isto satisfaz, pelo menos parcialmente o critério de origem biogênica $(t)$-presença de estruturas morfológicas muito delicadas, que por haver apenas um exemplar e por causa das outras depressões e vazios na rocha nada parecidos com objetos biológicos, ela classificou esta estrutura como dubiofóssil, eventualmente o molde externo de um cifozoário medusóide.

Em contraposição a uma origem biológica deverá ser lembrado que os medusóides fósseis do Vendiano (Fedonkin,1992) e do Cambriano Inferior (Rosanov \& Zhuravlev, 1992 e ZhiWen,1992) apresentam forma e simetria concêntrica e/ou radial bem distintas das do objeto analisado. Isto não exclui uma origem biológica mas também não favorece esta interpretação. Também é dificil imaginar feições internas como bolsões gástricos se ndo suficientemente rijos parar deixar uma impressão tridimensional em sedimentos arenosos relativamente grossos.

Há ainda a questão do porquê desta estrutura e das outras depressões nesta amostra estarem vazios. Dificilmente, este teria sido seu estado desde a época de sua formação. Os vazios atuais devem ter sido ocupados por algo, se não teriam sido fechados pela compactação sedimentar e tectônica da seqüência. Este ponto, nos remete ao critério de origem abiogênica (a), semelhança com estruturas sedimentares ou diageneticas. Em diversos níveis do afloramento onde foi coletada a amostra ocorrem intercalações e evidências de intraclastos argilosos. As depressões bem que poderiam representar tais clastos de argila, intenperizados e lixiviados.

A análise pende, assim, para uma origem inorgânica. No entanto, o formato tentadoramente sugestivo de uma afinidade com medusóides, mesmo que destacado artificialmente, nos leva a classificar esta estrutura com índice de biogenicidade 3, ou seja, possivelmente abiogênico,podendo representar um conjunto de pequenos clastos de argila, recobertos, casualmente, por um clasto placóide maior de forma eliptica. 


\subsubsection{Amostra GP/7E-218 (Amostra 3 de 1.2.86)}

\section{Descrição}

Arenito fino a médio $(177-350 \mu \mathrm{m})$, de coloração amarela, com grãos arredondados a subangulosos na parte superior (onde ocorrem os objetos), e grãos subarredondados a subangulosos na parte inferior. A laminação não é muito bem definida. $\mathrm{Na}$ superficie inferior, ocorrem marcas onduladas porém, devido ao seu formato pouco característico, não foi possível utiliza-las para definir topo e base na amostra.

A estrutura analisada compreende a camada superficial do outro lado da amostra com superficie densamente pustular, composta por vários objetos milimétricos a centimétricos, em semi-relevo convexo (Fig. 6.15)

\section{Discussão}

A superficie pustular não se enquadra em nenhum dos critérios de origem biogênica, lembra, vagamente, um denso campo de pequenas tocas rasas, mal preservadas em hiporrelevo convexo Enquadra-se nos seguintes critérios de origem abiogênica: critério (a) semelhança com estrutura sedimentar ou diagênica; critério (b) dimensões variáveis ou adelgaçadas; critério (c) tamanho e/ou forma não uniforme de múltiplas estruturas; e critério (d) padrão geométrico irregular. Assim sendo, são classificadas com índice de biogenicidade 1, ou seja, abiogênica ou pseudofóssil. Mesmo assim, a origem desta feição não é de fácil solução. Sua forma guarda certa semelhança com cristas de adesão (adhesion ripples), uma estrutura sedimentar gerada pela adesão de grãos transportados pelo vento em uma superfície arenosa saturada em água (Allen, 1984), sendo indicativa do topo da amostra. Esta é uma interpretação possível, tendo em vista as evidências de águas muito rasas e até eventual exposição subaérea no afloramento. (Fig. 6.15) 

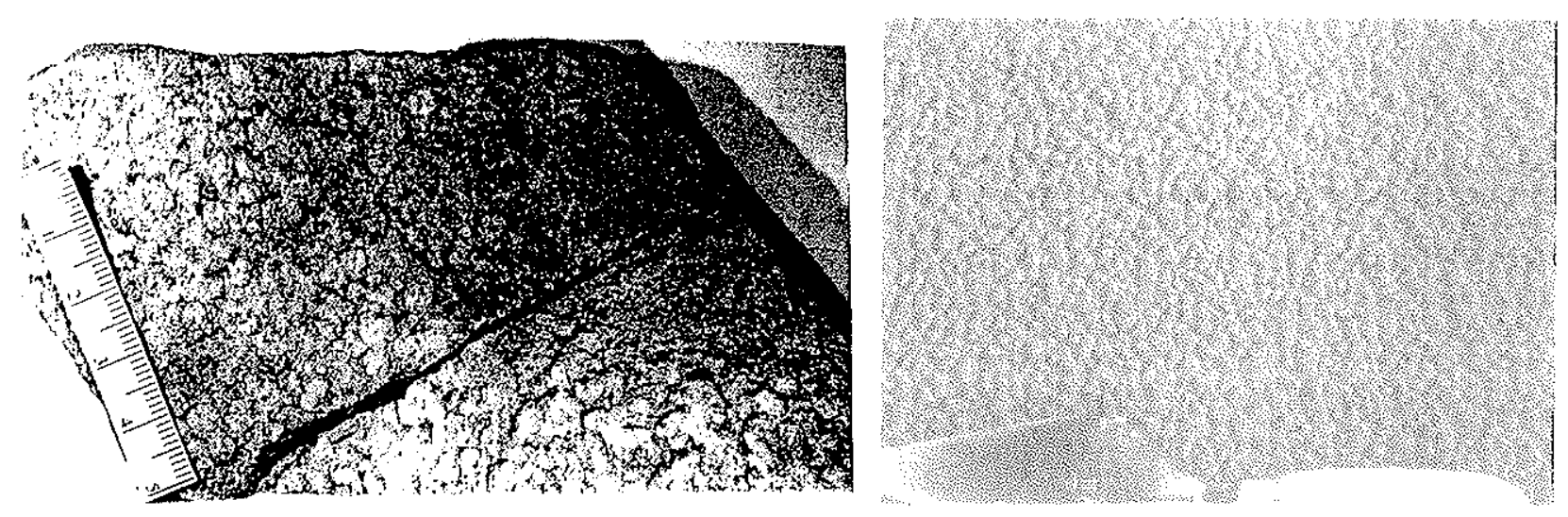

Figura 6.15 - À esquerda a amostra GP/7E-218 e a direita cristas de adesão modernas (Foto das cristas extraída de Allen, 1984).

\subsubsection{Amostra GP/7E-219 (Amostra 2 de 1.2.86)}

\section{Descrição}

Arenito fino a médio $(177-350 \mu \mathrm{m})$, de coloração amarela, com grãos subarredondados a subangulosos. Esta amostra divide-se em três partes: uma fina camada com espessura de aproximadamente $4 \mathrm{~mm}$, onde ocorre o objeto; uma camada intermediária mais espessa, com aproximadamente $12 \mathrm{~mm}$, com uma discreta laminação cruzada; e uma terceira camada com 3 a $6 \mathrm{~mm}$ de espessura, com laminação discretamente ondulada.

O objeto ocorre em semi-relevo côncavo, compreendendo uma depressão subcircular com $24 \mathrm{~mm}$ de diâmetro maior e $21 \mathrm{~mm}$ no seu diâmetro menor. Dentro desta depressão ocorre uma estrutura em relevo destacado do fundo, com sulcos semicirculares. Assim, como na amostra GP/7E-216, parte da estrutura (os sulcos) encontrarse salientada por grafite (lápis) (Fig. 6.16).

\section{Discussão}

Este objeto, que não foi discutido por Zaine, não é facilmente decifrável nem pelos critérios biogênicos nem pelos abiogênicos. Por um lado, sua estrutura interna lembra vagamente a impressão tri-radiciada Tribrachidium (Fedonkin,1992), especialmente após o destaque por 
lápis, enquanto, por outro lado, sua forma geral se assemelha a estruturas sedimentares do tipo marcas de obstáculo.

Talvez a chave para sua interpretação seja sua ocorrência no mesmo afloramento da amostra GP/7E-212, com objetos interpretados acima como possíveis pseudomorfos de cristais de gipsita. Visto por este ângulo, este objeto talvez represente o molde na base de uma camada de um conjunto de cristais evaporitico (barita?) do tipo "rosa do deserto", como o exemplar ilustrado na Fíg. 6.17. Sendo assim classificamos o objeto com índice de biogenicidade 3 , ou seja, possivelmente abiogênico, eventualmente o molde de uma estrutura evaporítica do tipo rosa do deserto.

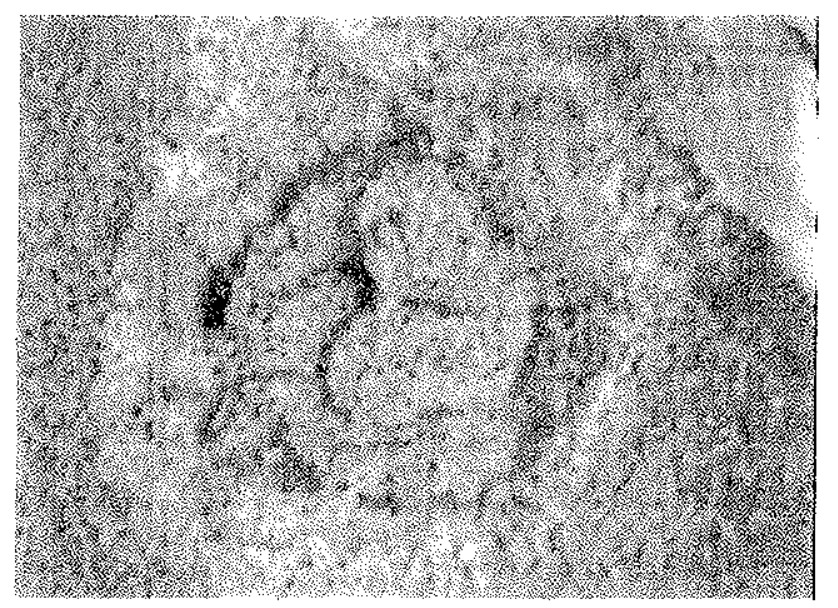

Figura 6.16 - Objeto na superfície da amostra GP/7E-219
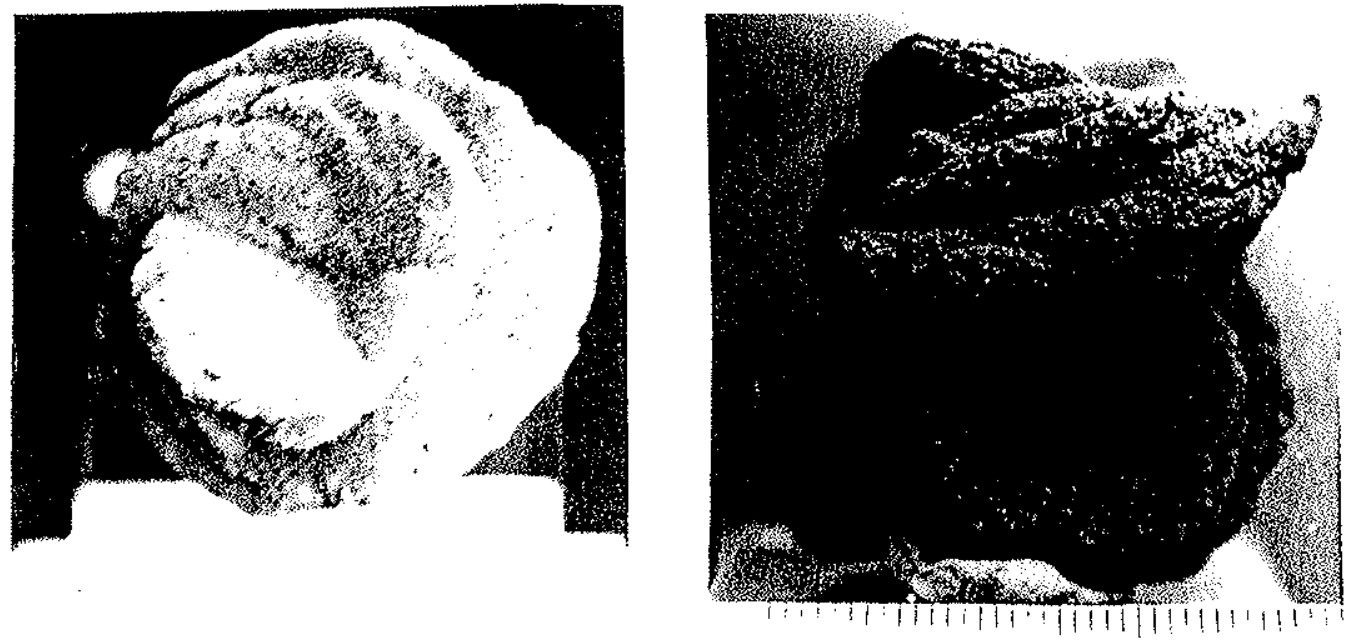

Figura 6.17 - rosa do deserto de barita em visão superior (a esquerda) e visão lateral (a direita). 


\subsubsection{Amostra GP/7E-220 (Amostra 5 de1.2.86)}

\section{Descrição}

Arenito fino a médio $(125-350 \mu \mathrm{m})$, de coloração rosa clara, grãos subangulosos a subarredondados, com presença de placas de argila e, ao menos, dois clastos de areniro muito fino de coloração rosa. A amostra contém, ainda, duas outras porções: uma fina camada de arenito laminado $(7 \mathrm{~mm})$, com granulometria variando de areia fina a média $(62$ $350 \mu \mathrm{m}$ ), relativamente mais fino que o resto da amostra; e um arenito muito fino a fino (62-125 um), de coloração rosa, que recobre o objeto em alguns pontos, e é bastante similar ao presente nos clastos (Fig. 6.18).

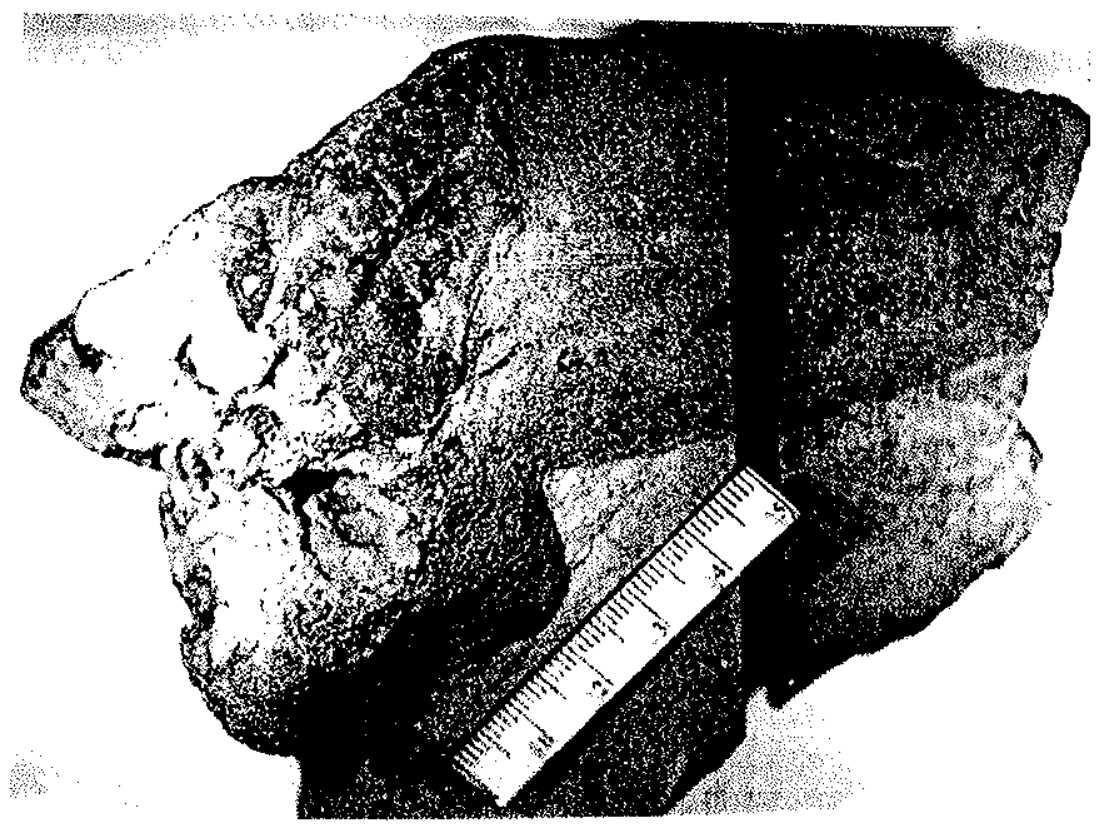

Figura 6.18 - Amostra GP/7E-220

O objeto apresenta semi-relevo convexo, e divide-se em duas porções distintas: um traço retilíneo, de aproximadamente $65 \mathrm{~mm}$ de comprimento, com largura variando entre 14 e 25 mm e altura entre 4 e $5 \mathrm{~mm}$; e uma massa irregular, com área de aproximadamente $24 \mathrm{~cm}^{2}$, com reentrâncias arredondadas, parcialmente preenchidas pelo mesmo material que recobre o objeto e ocorre como clastos lateralmente, mas no mesmo nível, a estas reentrâncias. 


\section{Discussão}

A estrutura do objeto não se enquadra em nenhum dos critérios de origem biogênica. Quanto à origem abiogênica, esta estrutura enquadra-se nos critérios (b) dimensões variáveis ou adelgadas, e (d) padrão geométrico irregular. Estes critérios, juntamente com a relação do objeto com o arenito que o recobre e ocorre como clastos, e também as reentrâncias, similares à forma dos clastos e parcialmente preenchidas por este arenito, indicam uma origem abiogênica para este objeto. Sendo assim, classificamos esta estrutura com índice de biogenicidade 1, ou seja, abiogênico ou pseudofóssil. Sendo interpretado como uma estrutura sedimentar de sobrecarga.

\subsection{Conclusões}

Ao contrario do que se imaginava inicialmente, os objetos pertencentes à Formação Raizama apontam, individualmente e em conjunto, mais para uma origem abiogênica do que biogênica para estas estruturas estruturas. Esta tendência, apoiada pela análise do conjunto dos objetos (Fig. 6.19), que demostra índices de biogenicidade entre 1 e 4, ou seja, entre pseudofóssil e dubiofóssil, também é reforçada pela raridade dos objetos potencialmente biológicos analisados aqui, muitos deles espécimes únicos.

A interpretação abiogênica dos objetos no presente trabalho, contrária à interpretação de Zaine (1991), devolve a Formação Raizama à condição de afossilifera ou, na melhor das hipóteses, dubiamente fossilífera. Esta condição é algo inesperado para rochas de ambiente marinho costeiro e suposta idade (final do Vendiano, início do Cambriano) compatíveis com a preservação de icnofósseis e fósseis corpóreos das primeiras faunas fósseis da história. 


\begin{tabular}{|c|c|c|c|c|c|}
\hline \multicolumn{2}{|c|}{ Amostra } & \multicolumn{2}{|c|}{ Classificação Zaine (1991) } & \multicolumn{2}{|c|}{ Classificação neste trabalho } \\
\hline $\begin{array}{c}\text { Número } \\
\text { da } \\
\text { Coleção }\end{array}$ & $\begin{array}{l}\text { Número } \\
\text { de } \\
\text { Campo }\end{array}$ & $\begin{array}{c}\text { Icnofóssil, } \\
\text { Dudiofóssil } \\
\text { ou } \\
\text { Pseudofóssil }\end{array}$ & $\begin{array}{c}\text { Nomenclatura } \\
\text { atribuída à } \\
\text { estrutura }\end{array}$ & $\begin{array}{c}\text { Indice de } \\
\text { Biogenicidade }\end{array}$ & $\begin{array}{c}\text { Nomenclatura } \\
\text { atribuída à } \\
\text { estrutura }\end{array}$ \\
\hline $\begin{array}{c}\text { GP/7E- } \\
210\end{array}$ & $2 / 2.2 .86 / 4$ & $\begin{array}{c}\text { Não } \\
\text { analisada }\end{array}$ & $X$ & 1 & $\begin{array}{l}\text { Gretas de } \\
\text { contração }\end{array}$ \\
\hline $\begin{array}{c}\text { GP/7E- } \\
211\end{array}$ & $2 / 3.2 .86 / 2$ & Icnofóssil & Cochlichmus sp. & 4 & Dubiofóssil \\
\hline $\begin{array}{l}\text { GP/7E- } \\
212 \\
\end{array}$ & $3 / 1.2 .86 / 4$ & Icnofóssil & $\begin{array}{l}\text { Planolites sp.l e } \\
\text { cf. Lockeia sp. }\end{array}$ & 2 & $\begin{array}{l}\text { Pseudomorfos de } \\
\text { cristais }\end{array}$ \\
\hline $\begin{array}{l}\text { GP/7E- } \\
213\end{array}$ & $2 / 2.2 .86 / 2$ & $\begin{array}{l}\text { Icnofóssil e } \\
\text { Dubiofóssil }\end{array}$ & $\begin{array}{l}\text { Planolites sp. } 2 \text { e } \\
\text { Dubiofóssil } 3\end{array}$ & 1 & $\begin{array}{l}\text { Rhysonetron } \\
\text { Pseudofóssil } \\
\end{array}$ \\
\hline $\begin{array}{l}\text { GP/7E- } \\
214 \\
\end{array}$ & $3 / 1.2 .86 / 6$ & Icnofóssil & Palaeophycus sp. & 1 & $\begin{array}{l}\text { Reflexo de } \\
\text { fraturas na rocha } \\
\end{array}$ \\
\hline $\begin{array}{l}\text { GP/7E- } \\
215\end{array}$ & $2 / 3.2 .86 / 1$ & Dubiofóssil & Dubiofóssil 1 & 3 & \begin{tabular}{|l|} 
Estrutura \\
sedimentar \\
\end{tabular} \\
\hline $\begin{array}{l}\text { GP/7E- } \\
216\end{array}$ & $3 / 1.2 .86 / 1$ & Dubiofóssil & Dubiofóssil 2 & 3 & $\begin{array}{l}\text { Clastos de argila } \\
\text { removidos }\end{array}$ \\
\hline $\begin{array}{l}\text { GP/7E- } \\
218\end{array}$ & $3 / 1.2 .86 / 3$ & $\begin{array}{c}\text { Não } \\
\text { analisada }\end{array}$ & $\mathrm{X}$ & 1 & Cristas de adesão \\
\hline $\begin{array}{c}\text { GP/7E- } \\
219 \\
\end{array}$ & $3 / 1.2 .86 / 2$ & $\begin{array}{c}\text { Não } \\
\text { analisada }\end{array}$ & $\mathrm{X}$ & 3 & Molde de cristais \\
\hline $\begin{array}{l}\text { GP/7E- } \\
220\end{array}$ & $3 / 1.2 .86 / 5$ & $\begin{array}{c}\text { Não } \\
\text { analisada }\end{array}$ & $X$ & 1 & $\begin{array}{l}\text { Estrutura de } \\
\text { sobrecarga }\end{array}$ \\
\hline
\end{tabular}

Figura 6.19 - Comparação das interpretações apresentadas por de Zaine (1991) e do presente trabalho.

Isto nos leva a perguntar, primeiro, se as interpretações da idade relativa (baseadas em correlações e isótopos de carbono) estão realmente corretas. Possivelmente, as datações radiométricas, que interpretamos anteriormente neste capitulo como altas demais, estão confiáveis e a Formação Raizama depositou-se antes do surgimento de metazoários megascópicos. Ou, talvez a ausência de fósseis resulta de impedimentos paleogeográficos ou paleoambientais, como por exemplo, deposição em altas latitudes, pouco habitadas nessa época, ou sob forte influência de águas continentais, pouco propicias ao desenvolvimento de vida animal época

Estas especulações, contudo, não encontram grande apoio nas evidências disponiveis, pois os dados estratigráficos, paleontológicos e isotópicos existentes para a Faixa Paraguai 
apóiam uma idade realmente pós-Varanger (>600Ma); a análise estratigráfica moderna da região norte da Faixa Paraguai, atualmente o foco de pesquisas por parte de A.C.R. Nogueira, acusa ambientes marinhos rasos normais, inclusive com épocas de considerável aridez e evaporação, condições pouco coerentes com latitudes altas

Talvez, a resposta ao problema seja mais simples, igual a tantas outras situações de seqüências supostamente afossiliferas, pois mesmo que nossos resultados indiquem uma origem abiogênica para os objetos estudados neste trabalho, vários deles continuam com sua origem sem definição precisa, e uma origem biológica não está por completo afastada. A chave certamente reside na necessidade de desenvolver novas pesquisas voltadas para a busca intensa, sistemática e continuada de possíveis fósseis nas fácies mais apropriadas da Formação Raizama. 


\section{Considerações finais}

O principal objetivo dessa dissertação, o estudo e aprendizado dos conceitos, aplicações e limitações da icnologia, foi plenamente alcançado com a análise dos objetos das formações Cariri e Raizama. Esta análise abrangeu todo o processo, desde a coleta de materiais no campo (Formação Cariri) até sua classificação final. O estudo destes diferentes objetos permitiu traballar com toda a gama de objetos, desde aqueles claramente abiogennicos até os de origem biogênica, passando por uma série de objetos de dificil interpretação e classificação.

Os objetos encontrados na Formação Cariri são de origem biogênica. Estes icnofósseis apesar de simples, representam a primeira ocorrência indubitável de icnofósseis de invertebrados nesta formação, até pouco tempo considerada afossilifera. Esta comprovação demonstra o potencial fossilifero desta unidade. As pesquisas nesta formação a partir de agora devem levar em conta este potencial.

Devido à sua simplicidade, estes icnofósseis não fornecerão as respostas definitivas para as grandes questões pendentes relativas a estratigrafia e idade da Formação Cariri. Mesmo assim, eles podem servir como um item a mais nas tentativas de correlação entre a Formação Cariri e formações similares das bacias correlatas próximas. Não é possivel fazer afirmações cronológicas com base nestes icnofósseis, pois, icnitos deste grau de simplicidade ocorrem ao longo de pode toda a faixa de idade já contemplada para esta formação. Mas, sua presença torna as hipóteses de uma idade ordoviciana a siluriana pouco provável.

Quanto às pegadas de dinossauros atribuidas anteriormente a esta formação, continua a dúvida se elas realmente pertencem a esta unidade. Isto se resolverá com o esclarecimento de sua localizaçâo estratigráfica (e geográfica) precisa.

Os objetos encontrados na Formação Raizama, e reavaliados nessa dissertação, apontam individualmente e em conjunto para uma origem abiogênica. Esta tendência é evidenciada 
pelos índices de biogenicidade destas amostras, sempre menor ou igual a 4 , ou seja entre dubiofósseis (4) e pseudofósseis (1), ao contrário do que se imaginava anteriormente.

A idade, próxima a transição Pré-Cambriano/Cambriano, geralmente aceita para estas rochas juntamente com seu ambiente deposicional marinho costeiro são, em princípio, propícios para se encontrar registros do surgimento e expansão inicial dos animais. Mas, diferentemente de diversas localidades de condições similares, estas rochas não apresentaram, até agora, nenhum indício convincente de atividade biológica. Isto nos leva a questionar se estas rochas foram depositadas em condições paleogeográficas ou paleoambientais realmente favoráveis à presença de vida, ou se a idade aceita para estas rochas está subestimada.

A pesquisa de vestígios de vida em ambas as formações deve ser ampliada no futuro. No caso da Formação Cariri, isto implicará na busca de novas evidências de vida que auxiliem na interpretação destas rochas, principalmente nos aspectos estratigráficos (idade deposicional e correlações). E no caso da Formação Raizama, as pesquisas paleontológicas deverão ser desenvolvidas sistemática e continuamente até esgotar toda a possibilidade desta unidade ser um registro de um dos períodos mais importantes da história da vida. 


\section{Referências bibliográficas}

ABEL, O. 1935. Vorzeitliche Lebensspuren. Jena, Gustav Fisher. 644p.

ACENOLAZA, F. G, 1978. El Paleozóico Inferior de Argentina segun sus trazas fosiles. Ameghiniana t. 15, n. 1-2, p. 15-64.

ALBUQUERQUE, P. R. F. SALES, A. M. F. \& ANDRADE, J. A.F.G. 1999. Traços fósseis na Formação Cariri (Paleozóico), Bacia do Araripe, CE. In: CONGRESSO BRASILEIRO DE PALEONTOLOGIA, 10. Resumos...Crato, CE, 1999, p.11.

ALBUQUERQUE, P. R. F.; SALES, A. M. F. \& ANDRADE, J. A.F.G. 2000. Trace fossils in the Cariri Formation, Araripe Plateau, Ceará, NE, Brasil. In: INTERNATIONAL GEOLOGICAL CONGRESS, 31. Abstracts... Rio de Janeiro, Brazil, 2000.

ALLEN, J. R. L. 1984. Sedimentary Structures. Their Character and Physical Basis. Unabridged one-volume edition, vol, I, 593 p. Vol. II, 663 p. Elsevier, Amsterdam (Developments in Sedimentology, 30).

ALMEIDA, F. F. M. 1954. Botucatu, um deserto triássico da América do Sul. Rio de Janeiro, DNPM/DGM, Notas preliminares e Estudos, 86, 21 p.

ALMEIDA, F. F. M. 1964. Geologia do centro-oeste matogrossense. Boletim da Divisão de Geologia e Mineralogia/DNPM, 215: 1-137.

ALMEIDA, F. F. M. 1984. Província Tocantins. Setor sudoeste. In: ALMEIDA, F. F. M. \& HASUI, Y. (coord.). O Pré-Cambriano do Brasil. Edgard Blücher. 265-281.

ALPERT, S. P. 1977. Trace fossils and the basal Cambrian boundary. In: CRIMES \& HARPER (eds.). Trace Fossils 2, Geological Journal Special Issue, 9, Sell House Press, Liverpool: 1-8.

ALVARENGA, C. J. S. 1984. Dobramentos da Faixa Paraguai na Borda sudeste do Craton Amazônico. In: CONGRESSO BRASILEIRO DE GEOLOGIA, 33, RIO DE Janeiro, 1984. Anais... Rio de Janeiro, SBG. V. 7, p. 3258-3271.

ALVARENGA, C. J. S. 1986. Evolução das deformaçốes polifásicas brasilianas na Faixa Paraguai, região de Cuiabá, MT. In: CONGRESSO BRASILEIRO DE GEOLOGLA, 34, Goiânia, 1986. Anais... Goiânia, SBG. v. 3, p. 1170-1175. 
ALVARENGA, C. J. S. \& TROMPETTE, R. 1992. Glacially influenced sedimentation in the Later Proterozoic of the Paraguai belt (Mato Grosso, Brazil). Palaeogeography, palaeoclimatology, Palaeoecology, 92 (1992): 85-105. Elsevier Science Publishers B.V., Amsterdam.

ANDREWS, H. N. 1970. Index of generic names of fossil plants. Bulletin of $U . S$. Geological Survey, 1300: 1820-1965.

ARAI, M \& COIMBRA, J.C.1990. Análise paleoecológica do registro das primeiras ingressões marinhas na Formação Santana (Cretáceo Inferior, Chapada do Araripe). In: SIMP. BACIA DO ARARIPE E BACIAS INTERIORES DO NORDESTE, 1.Crato, 1990.Anais...Crato, DNPM/SBP/SBG. P 225-239.

ASSINE, M.L. 1990. Sedimentação e Tectônica da Bacia do Araripe, Nordeste do Brasil. Rio Claro, 124 p. (Dissertação de Mestrado, IGCE/UNESP).

AUSSICH, W. I. 1979. Hondichnus monroensis n.gen. n.sp. a new Early Mississippian trace fossil. Jour. Paleont., 53: 1155-1159.

BAPTISTA, M. B., BRAUN, O. P. G., CAMPOS, D. de A. (orgs.). 1980. Léxico Estratigráfico do Brasil. DNPM/CPRM. Brasília, 560 p.

BASAN, P. B. (ed.). 1978a. Trace fossil concepts. Society of Economic Paleontologists and Mineralogist, Short Course, 5: 1-181.

BASAN, P. B. 1978b. Introduction. In: BASAN, P.B. (ed.) .1978. Trace fossil concepts. Society of Economic Paleontologists and Mineralogist, Short Course, 5 ; 1-8.

BASAN, P. B. 1979. Trace fossil nomenclature: The developing picture. Palaeogeography, Palaeoclimatology, Palaeoecology, 28: 143-167.

BATES, R.L.\& JACKSON, J.A., (eds)., 1987. Glossary of Geology, $3^{\text {rd }}$ ed. Alexandria, Virginia: American Geological Institute, 788p.

BENGTSON, S. 1994. The advent of animal skeletons. In: BENGTSON, S. (ed.) 1994. Early life on Earth. New York. Columbia University Press. p. 412-425. (Nobel Symposium No. 84).

BEURLEN, K.1962. A Geologia da Chapada do Araripe. An. Acad. Bras. Ciênc., 34 (3): 365-370

BEURLEN, K.1963. Geologia e estratigrafia da Chapada do Araripe. In: CONGR. BRAS. GEOL., 17. Recife, 1963. Anais...Recife, SBG/SUDENE. 47p. (Suplemento). 
BEURLEN, K.1966. Novos equinóides no Cretáceo do Nordeste do Brasil. An. Acad. bras. Ciênc.,389 (3/4): 455m464.

BEURLEN, K. 1971. As conđições ecológicas e faciológicas da Formação Santana na Chapada do Araripe (Nordeste do Brasil). An. Acad. Bras. Ciênc., 43 (supl.): 411-415.

BERTHOU, P-Y. 1994. Critical analysis of the main publications about the stratigraphical framework of the paleozoic and Mesozoic sedimentary deposits in the Araripe Basin (Northeastern Brasil). In: SIMP. CRETÁCEO DO BRASIL, 3. rio Claro, 1994. Boletim... Rio Claro, UNESP/IGCE. P. 123-126.

BERTHOU, P.Y; VIANA, M. S. S.; CAMPOS. D. DE A. 1990. Coupe de la formation Santana dans le secteur de "Pedra Branca" (Santana do Cariri) (Bassin d'Araripe, NE du Brésil). Contribuition a l'étude de la sédimentologie et des paleoenvinnements. In: SEMINÁRIO SOBRE A BACIA DO ARARIPE E BACIAS INTERIORES DO NORDESTE, 1. Crato, 1990. Atas... Crato, DNPM. p. 173-189.

BRASIER, M. D. 1982. Sea Level changes, fácies changes and the lower Precambrian Early Cambrian evolutionary explosion. Precambrian Research, 17: 105-123.

BRAUN, O.P.G. 1966.Estratigrafia dos Sedimentos da parte Inferior da Região Nordeste do Brasil (Bacias do Tucano-Jatobá, Mirandiba e Araripe). Rio de Janeiro, DNPM/DGM. 75p. (Boletim 236).

BOGGIANI, P. C. 1997. Análise estratigráfica da Bacia Corumbá (Neoproterozoico) Mato Grosso do Sul. São Paulo, (Tese Doutoramento), Instituto de Geociências da Universidade de São Paulo, 181 p..

BRAUN, O. P. G., 1966. Estratigrafia dos Sedimentos da Parte Inferior da Região Nordeste do Brasil (Bacias do Tucano-Jatobá, Mirandiba e Araripe). Rio de Janeiro, DNPM/DGM, 75p. (Bol. 236).

BROMLEY, R. G. 1990. Trace fossils - Biology and Taphonomy. Special Topics in Palaeontology, 3. Unwin Hyman. 280p.

CAMPANHA, V. A. 1979. Estruturas sedimentares biogênicas: conceitos básicos. Notícias Geomorfológicas, Campinas, 19 (37/38): 59-80.

CAMPOS, D.A. \& KELLER, A.W.A. 1985. Panorama of the flying reptiles study in Brazil and South América. An. Acad. bras. Ciênc., 57 (4): 453 466. 
CARVALHO, I. S. 2000. Geological environments of dinossaur footprints in the intracratonic basins of northeast Brazil during the early Cretaceous opening of South Atlantic. Cretaceous Research (2000) 21, 255-267 pp..

CARVALHO, I. S. \& FERNANDES, A. C. S. 1989. A icnocenose da Bacia de Taubaté: significado paleoambiental. In: CONGRESSO BRASILEIRO DE PALEONTOLOGIA, 11, Curitiba, 1989. Anais...Curitiba,SBP, 1: 419-426.

CARVALHO, I. S. \& FERNANDES, A. C. S. 2000. Icnofósseis. pp. 95-118. In: CARVALHO, I. S. (ed.). Paleontologia. Rio de Janeiro: Editora Interciência, 2000. p. 95-118.

CARVALHO, I. de S.; VIANA, M. S. S. \& LIMA-FILHO, M. F. 1995. Os icnofósseis de vertebrados da Bacia do Araripe. An. Acad. Bras. Ciênc. ,67, p. 433-442.

CARVALHO, P. F. 1936. Traços de vermes nos varvitos do Rio Itajaliy, Santa Catharina. Rio de Janeiro, SGM, Notas Preliminares e Estudos, 3: 1-2.

CIGUEL, J. H. G. \& ACENOLAZA, F. G. 1986. Icnologia da Formação Furnas (Paleozóico Médio), Bacia do Paraná. An. Acad. Brás. Ci., 58 (4): 595-596.

CIGUEL, J. H. G., GOIS, J. R. de \& ACENOLAZA, F. G. 1992. Ocorrência de icnofósseis em depósitos molássicos da Formação Camarinha (Neoproterozóico III - Cambriano Inferior), no Estado do Paraná, Brasil. Série Correlacion Geológica n. 9: 157-158.

CHAMBERLAIN, C. K. 1971. Morphology and ethology of trace fossils from the Ouachita mountains, southeast Oklahoma. Journal of Paleontology, 45(2): 212-246.

CHAMBERLAIN, C.K. 1978. Recognition of trace fossils in cores. In: BASAN, P.B. (ed.). 1978. Trace fossil concepts. Society of Economic Paleontologists and Mineralogist, Short Course, 5: 119-166.

CLARKE, J. M. 1899. A fauna siluriana superior do Rio Trombetas. Arch. Mus. Nac., Rio de Janeiro, 10: 1-48.

CONWAY-MORRIS, S. 1993. Ediacaran-like fossils in Cambrian burgess shale-type faunas of North América. Paleontology, 36: 593-635.

CORDANI, U. G.; KAWASHITA, K. \& THOMAZ-FILHO, A. 1978. Applicability of the rubidium-strontium method to shales and related rocks. American Association of Petroleum Geologists, Contributions to the Geologic Time Scale, Studies in Geology. 93-118. 
CORDANI, U. G.; THOMAZ-FILHO, A.; BRITO-NEVES, B.B. \& KAWASHITA, K. 1985. On the applicability of the Rb-Sr method to argilaceous sedimentary rocks: some examples form Precambrian sequences of Brazil. Giornale di Geologia, 47 (12): $253-280$.

COWIE, J. W. 1992. Two decades of research on the Proterozoic-Phanerozoic transition: 1972-1991. Journal of the Geological Society, London, v. 149, 1992, pp. 589-592.

CRIMES, T. P. 1974. Colonization of the early ocean floor, Nature, 248: 328-330.

CRIMES, T. P. 1975. The stratigraphical significance of trace fossils. In: FREY, R. W. 1975. The study of trace fossils - A synthesis of principles, problems and procedures in ichnology. Springer-Verger. 109-130.

CRIMES, T. P. 1987. Traces fossils and Correlation of late Precambrian and early Cambrian strata. Geological Magazine, 124 (2): 97-119.

CRIMES, T. P. 1989. Trace fossils. In: COWIE, J. W. \& BRASIER, M. D. (eds.) 1989. The Precambrian-Cambrian boundary. Claredon Press. 166-185.

CRIMES, T. P. 1992. The record of trace fossils across the Proterozoic-Cambrian bondary. In: LIPPS, J. H. \& SIGNOR, P. W. (eds) .1992. Origin and early evolution of the Metazoa. Plenum Press. 177-200.

CRIMES, T. P. \& HARPER, J. C. (eds.). 1970. Trace Fossils. Geological Journal, special Issue, 3, Sell House Press, Liverpool.

CRIMES, T. P. \& HARPER, J. C. (eds.). 1977. Trace Fossisl 2, Geological Journal, special Issue, 9, Sell House Press, Liverpool.

CRIMES, T. P. 1994. The period of early evolutionary failure and dawn of evolutionary success: The record of biotic changes across the Precambrian-Cambrian boundary. In: DONAVAN, S. K. (ed.). 1994. The palaeobiology of trace fossils. The Johns Hopkins University Press. 105-133.

D'ALESSANDRO, A. \& BROMLEY, R. G. 1987. Meniscate trace fossils and the Muensteria-Taenidium problem. Palaeont., 30: 743-763.

DEL' ARCO, J. O.; SILVA, R. H. DA; FREIRE, F. A; PEREIRA, L. G. M.; SOUZA, S. L. de; LUZ, S. D. da; PALMEIRA, R. C. B.; TASSINARI, C. C. C. (1982)-Geologia. In: PROJETO RADAMBRASIL. Folha SE.21 Corumbá e parte da Folha SE.20 Rio Janeiro, MME. p. 25-143 (Levantamento de Recursos naturais, 27). 
DERBY,O. A. 1879. Contribuiçôes para a geologia da região do baixo Amazonas. Arch. Mus. Nac., Rio de Janeiro, 2: 77-104.

DONOVAN, S. K. 1994. The palaeobiology of trace fossils. The Johns Hopkins University Press. 308p.

EKDALE, A. A. 1985. Paleoecology of the marine endobenthos. Palaeogeography, Palaeoclimatology, Palaeoecology, 50: 63-81.

EKDALE, A. A; BROMLEY, R. G. \& PEMBERTON, S. G. 1984. Ichnology - Trace fossils in sedimentology and stratigraphy. Society of Economic Paleontologists and Mineralogist, Short Course, 15.

FEDONKIN, M. A. 1992. Vendian faunas and the early evolution of Metazoa. In: LIPPS, J. H. \& SIGNOR, P. W. (ed.) Origin and early evolution of Metazoa. Plenum Press. 87-130.

FEDONKIN, M. A. 1994. Vendian body fossils and trace fossils, In: Bengtson, S. (ed.) Early Life on Earth. New York: Columbia University Press, p. 370-388. (Nobel Symposium n. 84).

FEITOSA, M.C.1987. Fácies Sedimentares e Modelo Deposicional dos Arenitos Inferiores do Vale do Cariri. Recife. 73p. (Dissertação de Mestrado, UFPE).

FERNANDES, A. C. S. 1993. Bibliografia indexada sobre estudos e registros de estruturas biogênicas no Brasil. Acta Geológica Leopoldesis, 37 (16): 49-106.

FERNANDES, A. C. S. \& NETTO, R. G. 1985. O estado atual da paleoicnologia no Paleozóico da Bacia do Paraná. In; CONGRESSO BRASILEIRO BRASILEIRO DE PALEONTOLOGIA, 9, Fortaleza, 1985. Resumos...Fortaleza, SBP, P. 41.

FERNANDES, A. C. S., BORGHI, L., MOREIRA, M. I. C. 2000. Sobre a ocorrência do icnogênero Arthrophycus Hall, 1852 na Formação Furnas (Bacia do Paraná). Boletim do Museu Nacional, Nova série, Geologia Rio de Janeiro, Brasil, n.52, p. 1-14, maio 2000.

FIGUEIREDO, A. J. A. \& OLIVATTI, O. 1974. Projeto Alto Guaporé. Relatório final. DGM/DNPM/CPRM. Vol. 11.

FOUCH, T. D., DEAN, W. E. 1982. Lacustrine Environments, p. 87-114. In: SCHOLLE, P. \& SPEARING, D. (eds.). 1982. Sandstone Depositional Environments, AAPG, Tulsa, Oklahoma 74101, USA, 410 p. 
FREY, R. W. 1973. Concepts in the study of biogenic sedimentary structures, Journal of Sedimentary Petrology, 43: 6-19.

FREY, R. W. 1975a. The study of trace fossils - A synthesis of principles, problems and procedures in ichnology. Springer-Verger. $562 \mathrm{p}$.

FREY, R. W. 1975b. The realm of ichnology, its strengths and limitations. In: FREY, R. W. (ed.). 1975. The study of trace fossils - A synthesis of principles, problems and procedures in ichnology. Springer-Verger. 13-38.

FREY, R. W. \& GOLDRING, R. 1992. Marine event beds and recolonization surfaces as revealed by trace fossil anylisis: Geological Magazine, 129: 325-335.85

FREY, R. W. \& PEMBERTON, S. G. 1985. Biogenic structures in outcrops and cones. I. Approaches to ichnology. Bulletin of Canadian Petroleum Geology, 33: 72-115.

FREY, R. W. \& SAILACHER, A. 1980. Uniformity in marine invertebrate ichnology. Lethaia, 13: 183-207.

FUCHS, T. 1895. Studien über fucoiden und hieroglyphen. Kaiserl. Akad. Wiss. Wien., 62: 369-448.

FÜRSICH, F. T. 1974a. Ichnogenerus Rhizocorallium. Paläontologische Zeitschrift, 48 : 16-28.

FÜRSICH, F. T. 1974b. On Diplocraterion Torell, 1870 and the significance of morphological features in vertical, spreite-bearinga, U-shaped trace fossils. Journal of Paleontology, 48: 952-962.

GASPARY, J. \& ANJOS, N. F. R. 1964. Estudo Hidrogeológico de Juazeiro do NorteCeará.Recife.SUDENE. 25p. (Série Hidrogeologia 3).

GHIGNONE, J. I. 1972. Ensaio de paleogeografia do Nordeste e as seqüencias sedimentares.In: CONGR. BRAS. GEOL., 26. Belém, 1972.Anais...Belém, SBG.v. $3, \mathrm{p} .21-28$.

GHIGNONE, J. I. 1979. Geologia dos sedimentos fanerozóicos do Estado da Bahia. Salvador, SME/BA.p. 24-117. (Textos Básicos 1).

GOROKHOV, I. M. \& MEL'NIKOV, N. N. 1997. Two different aprproaches to the use of the isochron method for dating sedimentary rocks. Stratigraphy and Geological Correlation, v. 5, n. 6, pp. 626-630. Translated from Stratigrafiya. Geologicheskaya, v. 5, n. 6, 1997, pp. 107-112. 
GRANT, S. W. F. 1990. Shell structure and distribution of clondina, a potencial index fossil for the terminal Proterozoic. Amer. Jour. of Science, 290-A: 261-294.

GLAESSNER, M. F. 1969. Trace fossils from the Precambrian and Basal Cambrian. Lethaia, 2: 369-393.

GLAESSNER, M. F. 1984. The down of animal life. A biohistorical study. Cambridge Earth Science Series. Cambridge University Press. 244p.

HAGADORN, J. W.; FEDO, C. M. \& WAGGONER, B. M. 2000. Early Cambrian Ediacaran-type fossils from Califórnia. Journal of Paleontology, 74: 731-740.

HALLAM, A. 1975. Preservation of trace fossils. In: FREY, R. W. 1975. The study of trace fossils - A synthesis of principles, problems and procedures in ichnology. Springer-Verger. 55-63.

HÄNTZSCHEL, W. 1962. Trace fossils and problematica. In: MOORE, R. C. (ed.) Treatise on invertebrate paleontology. Part W, Miscellanea. Geological Society of America e University Kansas Press. W177-W25.

HÄNTZSCHEL, W. 1965. Vestigia invertebratorum et problematica. Fossilium Catalogus, 1: Animalia, pars 108, 1-142.

HÄNTZSCHEL, W. 1975. Trace fossils and problematica. Treatise on Invertebrate Paleontology, Part W Miscellanea, Supplement 1. The Geological Society of America; The University of Kansas and Boulder and Lawrence. 269p.

HÄNTZSCHEL, W. \& KRAUS, O. 1972. Names based on trace fossils (icnotaxa): request for a recommendation. Bulletin of Zoological Nomenclature, 29: 137-141.

HASIOTS, S. T. \& BOWN, T. M. 1992. Invertebrate trace fossils: the backbone of continental ichnology. In: MAPLES, C. G. \& WEST, R. R. .1992. Traces fossils. Short Courses in Paleontology, 5: 64-104.

HASS, O. 1954. Zur definition des bergriffs "lebensspunen". Neues Jahrb. Geologie Palöontologie, Monatsh, 8: 1-379.

HOFMANN, H. J. 1967. Precambrian fossils (?) near Elliot Lake, Ontario. Science, 156 (3774): 500-504.

HOFMANN, H. J. 1971. Precambrian fossils, pseudofossils, and problematica in Canada. Bulletin of Geological Survey of Canada, 189: 1-146. 
HOFMANN, H. J. 1987. Precambrian biostratigraphy. Geoscience Canada, 14 (3): $135-$ 154.

HOWARD, J. D. 1978. Sedimentology and trace fossils. In: BASAN, P. B. (ed.) 1978. Trace fossil concepts. Society of Economic Paleontologists and Mineralogist, Short Course, $5: 11-42$.

HENNIES, W. T. 1966. Geologia do Centro-Norte matogrossense. São Paulo. 65p. (Tese de Doutoramento - Escola Politécnica/USP)

HUENE, F. F. von. 1931. Verschiedene mesozoiische wirbeltierrestre aus Sudamerika. $N$. Jb. Miner. Geol. Paleont., Stuttgart, B. 66, Abt. B. 181-196.

JAMES, J. F. 1884. The fucoides of the Cincinnati Group, Part 1. Journal of Cincinnati Society of Natural History, 7: 124-132.

JAMES, J. F. 1885. The fucoides of the Cincinnati Group, Part 2. Journal of Cincinnati Society of Natural History, 7: 151-166.

JENSEN S. 1997. Trace fossils from the Lower Cambrian Mickwitzia sandstone, southcentral Sweden: Fossils and Strata, v. 42, p. 1-110.

JENSEN S. \& GRANT, S. W. F. 1993. Implications from trace fossils for the VendianCambrian boundary in the Torneträsk Formatiom, northern Sweden. In: Siverson, M. (ed.). Lundadagarna i Historisk geologi och paleontologi III, Abstracts p. 15, (Lund Publications in Geology 109).

JENSEN S. \& GRANT, S. W. F. 1998. Trace fossils from the Dividalen Group, northern Sweden: Implications for Early Cambrian biostratigraphipy of Báltica: Norsk Geologisk Tidsskrift, v. 78, p. 305-317.

KELLNER, A. W. A.; SCHWANKE, C.; CAMPOS, A. DE A. 1999. O Brasil no tempo dos dinossauros. Rio de Janeiro, Museu Nacional. v 1, 60p. (séries livros 7).

KERR, R. A. 1998. Tracks of billion-year-old animals? Science, v. 282, 19-20.

KILLICK, A. M. 1983. A preliminary account of the geology of the Kamtsas Formation of the Damara sequence, eastern Gobabis district, south west África/ Namibia, Transactions of the Geological Society of South Africa, 86: 11-18.

KAUFFMAN, E. G. \& STEIDTMANN,J. R. 1981. Are these the olderst metazoan trace fossils?, Journal of Paleontological, 55: 923-947.

KNOLL, A. H. 1996. Daughter of Time. Paleobiology, 22: 1-7. 
KUMMEL, B. \& RAUP, D. 1965. Handbook of Paleontological techniques. San Francisco, Freeman, 852p.

LEINZ, V. 1937. Estudos sobre glaciação Permo-carconifera do sul do Brasil. Rio de Janeiro, Serv. Fom. Prod. Min., Boletim, 21, 47 p.

LEONARDI, G. 1979. Um Glossário Comparado da Icnologia dos Vertebrados. Ponta Grossa, Univ. Est. Ponta Grossa, Cadernos Universitários, 17, 55 p.

LEONARDI, G. 1987. (ed.) Glossary and Manual of Tetrapod Footprint Palaeoichnology. Brasília, Min. Minas e Energia, DNPM, 117 p..

LEONARDI, G. \& SARJEANT, W. A. S. 1986. Footprints represeting a new mesozoic vertebrate fauna from Brazil. Modern Geology, 10; 73-84.

LESSAERTISSEUR, J. 1955. Traces fossiles d'activité animale et leur signification paléobiologique. Mémoirs de Societé Géologic de France, 74: 1-150.

LIMA, M. R.1978a. Palinologia da Formação Santana (Cretáceo do Nordeste do Brasil). São Paulo, 335 p. (Tese de Doutoramento, IG/USP).

LIMA, M. R. 1978b. Microfósseis da Formação Exu - Cretáceo do Nordeste do Brasil In: CONGR. BRAS. GEOL., 30.Recife, 1978. Anais...Recife, SBG.v. 2, p.965-969.

LIMA, M. R. 1979. Considerações sobre a subdivisão estratigráfica da Formação Santana -Cretáceo do Nordeste do Brasil. Rev. Bras. Geoc., 9 (2):116-121.

LOCKLEY, M. G.; HUNT A.P. \& MEYER, C. A. 1994. In: DONAVAN, S. K. (ed). The Paleobiology of Trace Fossils. The Johns Hopkins University Press, Baltimore, USA.

MABESOONE, J. M. \& TINOCO, I. M. 1973. Paleoecology of Aptian Santana Formation (Northeastern Brazil). Palaeogeogr, Palaeoclim. Palaeocol.,14 (2): 87-118.

MACNAUGHTON \& NARBONNE, G. M. 1999. Evolution and ecology of Neoproterozoic-Lower Cambrian Trace Fossils, NW Canada. Palaios, 1999, v. 14, p. 97-115.

MAILlLARD, G. 1887. Considérations sur les fossiles décrits comme algues. Mémoirs de Societé Paléontologie Suisse, 14: 1-40.

MAISEY, J. G. (ed.) 1991. Santana Fossils: an illustrated atlas. Tropical Fish Hobbyist Publications, New Jersey, USA, 459 pp.

MAPLES, C. G. \& WEST, R. R. 1992. Traces fossils. Short Courses in Paleontology, 5. 
MARTILL, D. M. 1993. Fossils os the Santana and Crato Formations. Brazil. London, The Palaeontological Association. 159 p. (Field Guides to fossils 5).

MARTILL, D. M. 1988. Preservation of fish in Cretaceous Santana Formation of Brazil. Paleontology, 31:1-18.

MARTINS-NETO, R. G.1990. Sistemática dos Ensifera (Insecta, Orthopteroida) da Formação Santana, Cretáceo Inferior do Nordeste do Brasil. São Paulo $267 \mathrm{p}$. (Dissertação de Mestrado IG/USP).

MARTINSSON, A. 1965. Aspects of a Middle Cambrian thanatope on Öland. Geol. Fören. Stockholm Förhandl, 87: 181-230.

MARTINSSON, A. 1970. Taphonomy of trace fossils. Geological Journal, Special Issue, 3: $323-330$.

MAURY, C. J. 1927. Fósseis silurianos de Santa Catarina. Rio de Janeiro, SGM, Boletin, $23,15 \mathrm{p}$.

MEDEIROS, R. A. ; PONTE, F. C.; PONTE-FILHO, F. C. 1997. Análise estratigráfica da Bacia do Araripe: parte 2 -análise de fácies. In: SEMINÁRIO SOBRE A BACIA DO ARARIPE E BACIAS INTERIORES DO NORDESTE, 2. Crato, 1997. Atas... Crato, DNPM. P. 18-19.

MIZUSAKI, A. M.; KAWASHITA, K.; CORDANI, U.G.; THOMAS-FILHO, A. 1993. Rubídio e estrôncio em sedimentos recentes: implicações na datação radiométrica de rochas sedimentares argilosas. In: Semana de Geoquímica, 9., e Congresso de Geoquímica dos Países de lingua Portuguesa, 2., Porto, Portugal. Universidade do Porto, Faculdade de Ciências, Museu e Laboratório Mineralógico e Geológico, Memórias n. 3 (NORONHA, F.; MARQUES, M.; NOGUEIRA, P. eds.), p. 405-409.

MORAES, L. J. 1924. Serras e montanhas do Nordeste. Brasil, Insp. Obr. Contra Secas, série I-D, Publ. 58, $2 \mathrm{v}$.

MUNIS, G. da C. B. 1980. Cochlichnus lagartensis Icnosp. Nov., Ichnofóssil da Formação Lagarto, Grupo Estância, no estado de Sergipe. Anais...CONGRESSO BRASILEIRO DE GEOLOGIA, 31, Balneário de Camburiú, Santa Catarina, 1980, v. 5:3101-3105.

NARBONNE, G. M. \& MYROW, P. M. 1988. Trace fossil biostratigraphy in the Precambrian-Cambrian boundary interval. In: LANDING, E; NARBONE, G. M. \& 
MYROW, P. M (eds.). Trace Fossils, Small Shelly Fossils and PrecambrianCambrian Boundary, 72-76. New York State Museum Bulletin 463.

NARBONNE, G. M., MYROW, P. M., LAUNDING, M. M. 1987. A candidate stratotype for the Precambrian-Cambrian boundary, Fortune dead, Burin Penisula, southeastern Newfoundland.Can. J, earth. Sci., 24, p. 1277-1293, Geol. Series New York Museum, Public. N. 534.

NATHORST, A. G. 1881. Om spar af nagra evertebrerade djur M. M. och deras paleontologiska betydelse. (Mémoire sur quelques traces d'animaux sans vertebrés etc. et de leur portée paléontogique) Kgl. Svensk. Akad. Handl., 18: 1-140.

NATHORST, A. G. 1886. Nouvelles observations sur les traces d'animaus et autres phénomènes d'origine purement mécanique décrits comme "algues fossiles" $\mathrm{Kgl}$. Svensk. Akad. Handl., 21: 1-58

NOGUEIRA, A. C. R. 1995. "Análise Faciológica e aspectos estruturais da Formação Águas Claras, região Central da Serra dos Carajás-PA", Belém, (Tese de Mestrado) 1995, UFPA, Centro de Geoc., Curso de Pós-Graduação em Geologia e Geoquímica.

NOGUEIRA, A. C. R., TRUCKENBRODT, W., SOARES, E. A. A. 2001. O icnogênero Arthrophycus de depósitos sublitorâneos da Formação Nhamundá (Siluriano Inferior) da Bacia do Amazonas, Região de Presidente Figueiredo. Revista Brasileira de geologia, 2001, (no prelo).

OLIVATTI, O. 1981. Problemas estratigráficos do Pré-Cambriano na região sudoeste do estado do Mato Grosso - Tentativa de correlação com a geologia do oriente boliviano. Ata do Simpósio de Geologia do Centro-Oeste, 1: 196-211.

OSGOOD, R. G. 1970. Trace fossils of the Cincinnati area. Palaeontographica Amer., 6 (41): 281-444.

OSGOOD, R. G. 1975a. The history of invertebrate ichnology. In: FREY, R. W. 1975. The study of trace fossils - A synthesis of principles, problems and procedures in ichnology. Springer-Verger. 3-12.

OSGOOD, R. G. 1975b. The paleontological significance of trace fossils. In: FREY, R. W. 1975. The study of trace fossils - A synthesis of principles, problems and procedures in ichnology. Springer-Verger. 87-108. 
PEMBERTON, S. G. (org.). 1992. Applications of Ichnology to Petroleum Exploration. A core workshop 17, 1992,SEPM, Tulsa, 429 p.

PEMBERTON, S. G. \& FREY, R. W. 1982. Trace fossil nomenclature and the PlanolitesPalaeophycus dilemma. Journal of Paleontology, 56 (4): 843-881.

PEMBERTON, G. S., FREY, R. W. \& SAUNDERS, T. D. A. 1990. Trace Fossils. p. 355 362. In: (eds.) BRIGGS, E. G. D. \& CROWTHER, P. R. 1990. Palaeobiology: a synthesis. Blackwell Science, 583 p.

PEMBERTON, G. S., MACEACHERN \& FREY, R. W. 1992. Trace Fossils Facies Models: Envirommental and Allostratigraphic Significance. In: WALKER, R. G. \& JAMES, N. P. (eds.). Facies Model: Response to Sea Level Change, Geological Society of Canadá, p. 47-72.

PETRI, S. 1985. Ritmitos de Itu. In: SIMPOSIO REGINAL DE GEOLOGIA, 5, São Paulo, 1985. Atas... São Paulo, SBG, 1: 235-241.

PICKERILL, R. K. 1994. Nomenclature and taxonomy of invertebrate trace fossils. In: DONAVAN, S. K. 1994. The palaeobiology of trace fossils. The Jolns Hopkins University Press. 3-42.

PLUMMER, P. S. \& GOSTIN, V. A. 1981. Shrinkage cracks: desiccation or synaeresis? Journal of sedimentary Petrology, SEPM, v. 51, n. 4, December, 1981, p. 1147-1156.

PONTE, F. C. 1992. Origem e evolução das pequenas bacias cretácicas do interior do nordeste do Brasil. In: SIMPÓSIO SOBRE AS BACIAS CRETÁCICAS BRASILEIRAS, 2, Rio Claro, 1992. Resumos Expandidos... Rio Claro, UNESP/IGCE. p. 55-58.

PONTE, F. C.; MEDEIROS, R. A.; PONTE FILHO, F. C. 1997. Análise estratigráfica da Bacia do Araripe: parte I - análise de seqüências. In: SEMINÁRIO SOBRE A BACIA DO ARARIPE E BACIAS INTERIORES DO NORDESTE, 2. Crato, 1997. Atas... Crato, DNPM.p. 17.

PRICE, L. I. 1971.A presença de Pterosauria no Cretáceo Inferior da Chapada do Araripe, Brasil. An. Acad. bras. Ciênc. 43 (supl.): 451-461.

PRICE, L. 1. 1973. Quelônio Amphychelidia no Cretáceo Inferior do Nordeste do Brasil. Rev. Bras. Geoc. $3(2): 84-95$. 
RICHTER, R. 1927. Die fossilien Fährteen und Bauter der Würmer, ein Überblick über ihre biologischen Grundformen und deren geologische Bedeutung. Paläont. Zeitschr., 9: $193-240$.

RICHTER, R. 1928. Psychische reaktionen fossiler tiene. Paleobiologica, 1: 225-244.

RICHTER, R. 1931. Tierwelt und unwelt im hunsrückschiefer zur entstehung eins schwarzen schlammsteins. Seenckenbergiana, 13: 299-324.

RHOADS, D. C. 1975. The paleontological and environmental significance of trace fossils. In: FREY, R. W. 1975. The study of trace fossils - A synthesis of principles, problems and procedures in ichnology. Springer-Verger. 147-160.

ROCHA-CAMPOS, A. C. 1967. The Tubarão Group in Brasilian portion of the Paraná Basin. In: BIGARELLA, J.J., BECKER, R.D. \& PINTO, I. D. (eds.), Problems in Brasilian Gondwana, Curitiba, p. 27-102.

ROSANOV, A. Y.1992. Some problems concerning the Precambrian- Cambrian transition and the Cambrian faunal radiation. Journal of Geological Society, London 149: 593598.

ROZANOV, A. Y. \& ZHURAVLEV, A.Y. 1992. The Lower Cambrian Fossil Record of the Soviet Union, p 205-282. In: (eds.) LIPPS, J. H. \& SIGNOR, P. W..1992. Origin and Early Evolution of the Metazoa, Plenum Press, New York, 570 p.

ROWLAND, S. M;; LUCHININA, V. A.; KOROVIKNOV, I. V.; SIPIN, D. P.; TARLETSKOV, A. I.; FEDOSEEV, A. V. 1998. Biostratigraphy of the VendianCambrian Sukharikha River Section, northwestern Siberian Plataform. Can. J. Earth Sc. 35:339-359.

RUNNEGAR, B. N. 1992. Evolution of the earliest animals. In: SCHOPF, J.W. (ed.) 1992. Major events in the history of life. Boston. Jones and Bartletl Publishers. p, 65-93.

SARJEANT, W. A. S. 1979. Code for trace fossi nomenclature. Palaeogeography, Palaeoclimatology, Palaeoecology, 28: 147-167.

SARJEANT, W. A. S. \& KENEDY, W. J. 1973. Proposal of a code for the trace fossils. Canadian Journal of Earth Science, 10: 460-475.

SALES, A. M. F; GHILARDI, R. P.; LIMA FILHO, F. P. 1999. Sobre as coquinas calcáreas do Membro Romualdo, Formação Santana (Cretáceo) Bacia do Araripe, 
uma contribuição estratigráfica. In: CONGRESSO BRASILEIRO DE PALEONTOLOGIA, 10. Resumos...Crato, CE, 1999, p. 93.

SCHOPF, J. W. 1983. Glossary 1. Technical terms. In: SCHOPF, J. W. (ed.) Earth's earliest biosphere. Its origin and evolution. Princeton, Princeton University Press, EUA. p.443-458.

SCHOPF, J. W. 1992. The oldest fossils and what they mean. In: SCHOPF, J.W. (ed.) 1992. Major events in the history of life. Boston. Jones and Bartletl Publishers. p.2963.

SEILACHER, A. 1953. Über die methoden der palichnologie. 1. Studien zur palichnologie. Neues Jahrb. Geol. Paläont, Abh., 96 421-452.

SEILACHER, A. 1955. Spuren und lebensweise der trilobiten; Spuren und fazies im unterkambrium. In: SCHINDEWOLF, O. H. \& SEILACHER, A. .1955. Beiträge zur kenntis des kambrius in der Salt Range (Pakistan). Akad. Wiss. U. Lit. Mains, Mathnaturw. Kl., Abh., 10: 342-399.

SEILACHER, A. 1956 der Begin des Kambriums als biologische Wende, Neues Jahrbuch für Geologie und Paäontologie Abhandlungen, 103: 155-80.

SEILACHER, A. 1964a. Sedimentological classification and nomeclature of trace fossils. Sedimentology, 3: 253-256.

SEILACHER, A. 1964b. Biogenic sedimentary structures. In: IMBRIE, J. \& NEWELL, N. D. (eds.) Approaches to paleoecology. John Wiley. 296-316.

SEILACHER, A. 1967a.Bathymetry of trace fossils. Mar. Geol. 5, 413-28.

SEILACHER, A. 1967b. Fossil behaviour. Sci. Amer. 217, 72-80.

SEILACHER, A., BOSE, P. K. \& PFLÜGER, F. 1998. Triploblastic Animals More Than 1 Billion Years Ago: Trace Fossil Evidence from Índia. Science, v. 282, 80-83.

SEILACHER, A., MESCHEDE, M., BOLTON, E. W. \& LUGINSLAND, H. 2000. Precambrian "fossil" Vermiforma is a tectograph. Geology; March 2000; v. 28; n. 3; p. 235-238.

SIMPSON, S. 1957. On the trace fossil Chondrites. Quart. Jour. Geol. Soc., London 107, 475-99. 
SILVA-SANTOS, R. DE. 1991. Fósseis do Nordeste do Brasil. Paleoictiofáunula da Chapada do Araripe. Rio de Janeiro, UERJ/Instituto de Biologia/Departamento de Biologia Animal e Vegetal. 62p.

SILVA-SANTOS, R. de \& VALENÇA, J. G. 1986. A Formação Santana e sua paleoictiofauna. An. Acad. Bras. Ciênc., 40 (3): 357-360.

SOKOLOV, B. S. 1995. The Vendian Sytem and "Neoproterzoic III". Stratigraphy and Geological Correlation, 3: 575-590.

SRIVASTAVA, N. K. 2000. Estromatólitos. In: CARVALHO, I. S. (ed.) Paleontologia. Rio de Janeiro: Editora Interciência, 2000. p. 119-136.

TURNER, B. R. \& BENTON, M. J. 1983. Paleozoic trace fossils from the Kufra Basin, Libya. (eds.) SEPM \& Paleont. Soc., Jornal of Paleontology, v. 57, n. 3, p. 447-460.

VINOGRADOV, V. I. 1997. Rb-Sr and K-Ar Isotope Datings of Blue Clays in the Baltic Region: Implications for Geology. Stratigraphy and Geological Correlation, vol. 5, n. 6, 1997, pp. 620-625. Translated from Stratigrafiya. Geologicheskaya, vol. 5, n. 6, 1997, pp. 101-106.

VIEIRA, A. J. 1965. A geologia do centromoeste de Mato-Grosso. Ponta Grossa, Petrobrás (Relatório interno 303), 58p.

WALTER, M. R. \& HEYS, G. R. 1985. Links between the rise of Metazoa and the decline of Stromatolites. Precambrian Research 29:149-174.

ZAINE, M. F. 1991. Análise dos fósseis de parte da Faixa Paraguai (MS, MT) e seu contexto temporal e paleoambiental. São Paulo, 1991, (Tese de Doutoramento, Instituto de Geociências da Universidade de São Paulo), 215 p.

ZHI-WEN, J. 1992. The Lower Cambrian Fossil Record of China, p 311-333. In: LIPPS, J.H. \& SIGNOR, P. W. (eds.).1992. Origin and Early Evolution of the Metazoa, Plenum Press, New York, 570 p. 